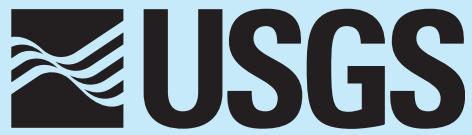

science for a changing world

Prepared in cooperation with the Metro Wastewater Reclamation District

\title{
Biosolids, Crop, and Groundwater Data for a Biosolids-Application Area near Deer Trail, Colorado, 2007 and 2008
}

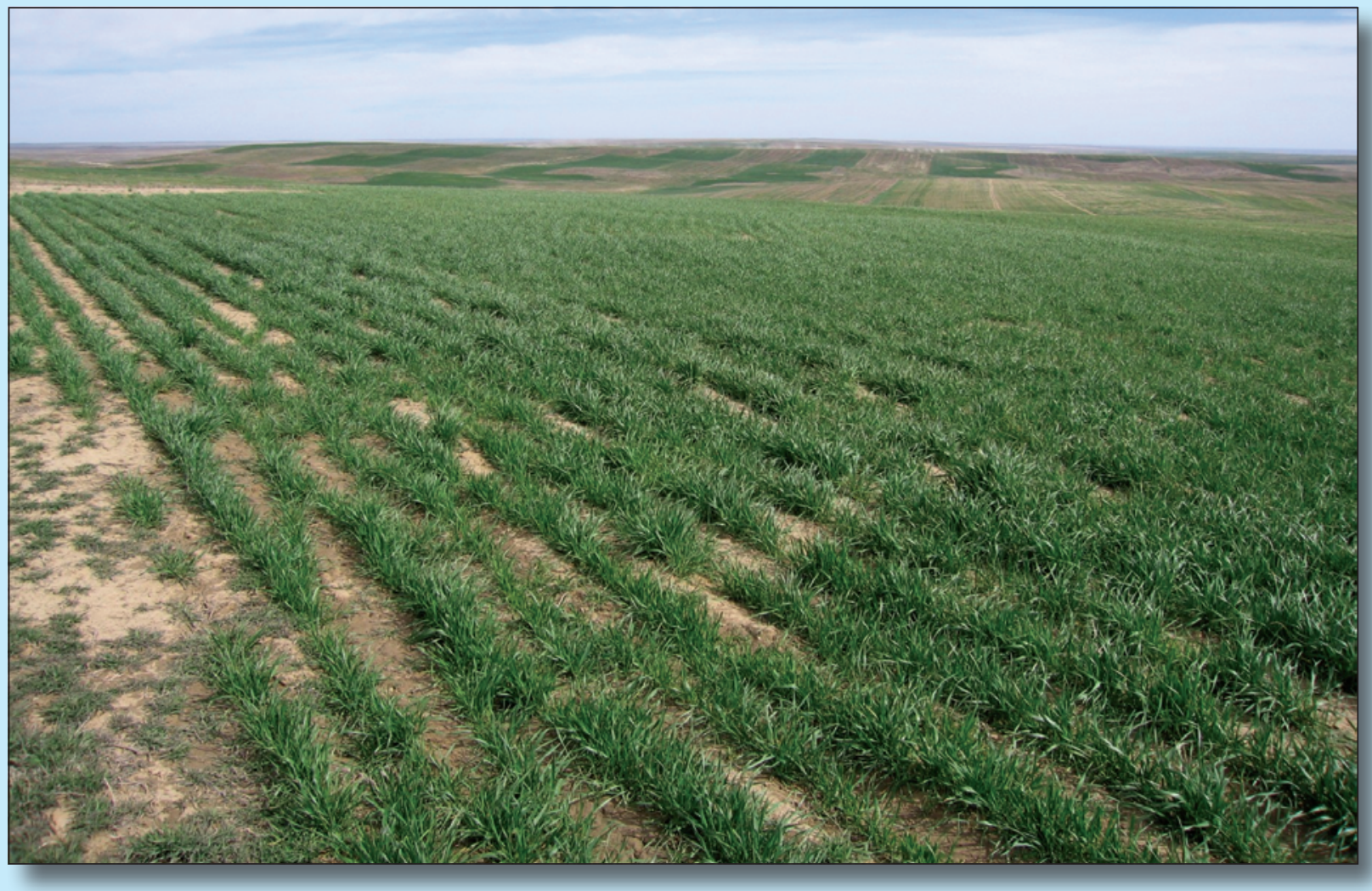

Data Series 589 



\section{Biosolids, Crop, and Groundwater Data for a Biosolids-Application Area near Deer Trail, Colorado, 2007 and 2008}

By Tracy J.B. Yager, David B. Smith, and James G. Crock

Prepared in cooperation with the Metro Wastewater Reclamation District

Data Series 589 


\title{
U.S. Department of the Interior \\ KEN SALAZAR, Secretary \\ U.S. Geological Survey \\ Marcia K. McNutt, Director
}

\section{U.S. Geological Survey, Reston, Virginia: 2011}

For more information on the USGS — the Federal source for science about the Earth, its natural and living resources, natural hazards, and the environment:

World Wide Web: http://www.usgs.gov

Telephone: 1-888-ASK-USGS

\author{
Any use of trade, product, or firm names is for descriptive purposes only and does not imply \\ endorsement by the U.S. Government. \\ Although this report is in the public domain, permission must be secured from the individual \\ copyright owners to reproduce any copyrighted material contained within this report. \\ Suggested citation: \\ Yager, T.J.B., Smith, D.B., and Crock, J.G., 2011, Biosolids, crop, and groundwater data for a biosolids-application area \\ near Deer Trail, Colorado, 2007 and 2008: U.S. Geological Survey Data Series 589, 53 p.
}




\section{Contents}

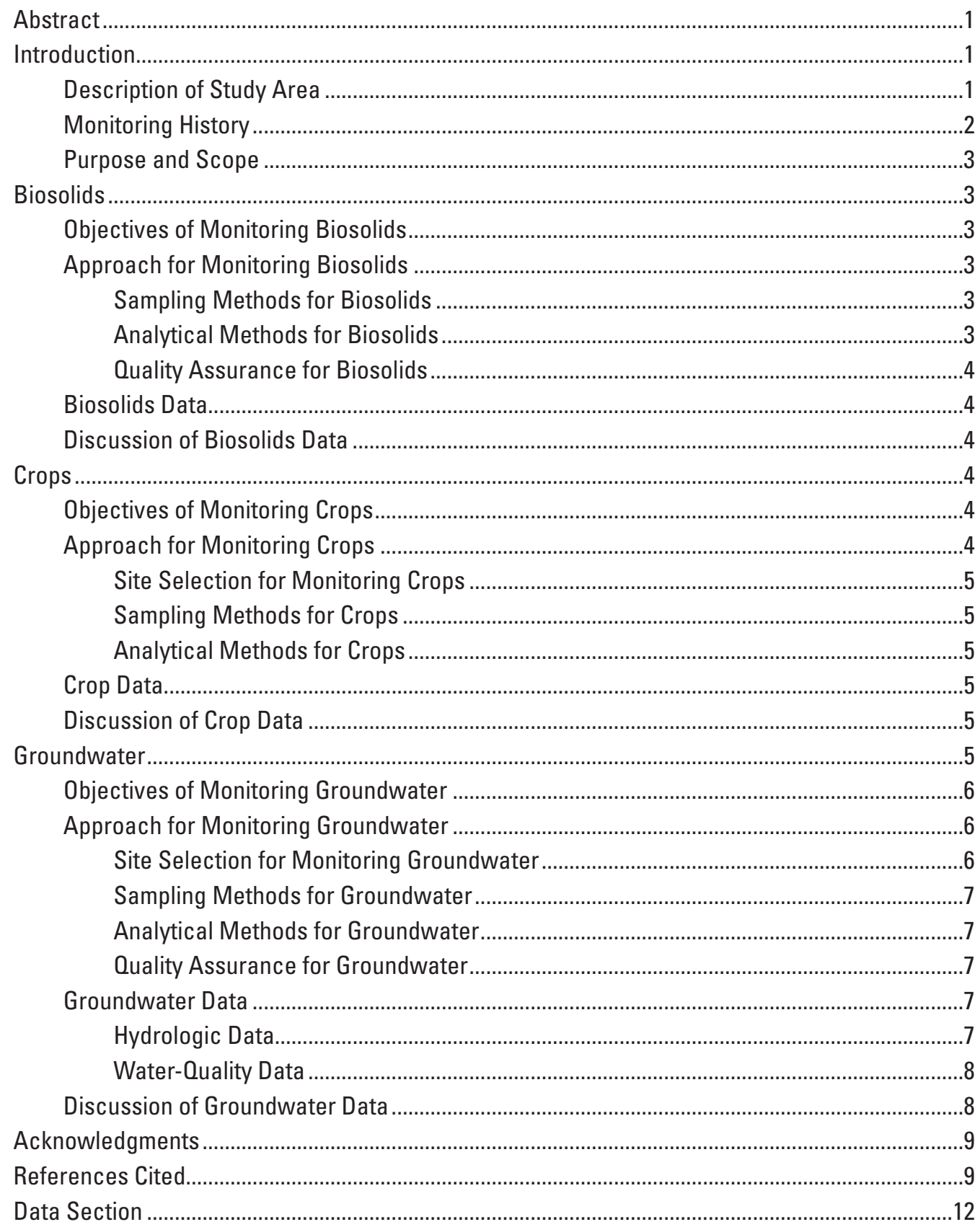




\section{Figures}

1. Location of study area near Deer Trail, Colorado

2. Location of U.S. Geological Survey Expanded Monitoring Program sites near Deer Trail, Colorado, 2007 and 2008.

3. Locations of U.S. Geological Survey monitoring wells during 2007 and 2008 on the original (1993-1995) Metro Wastewater Reclamation District property near Deer Trail, Colorado, now part of the METROGRO Farm central property. 15

4. Metro Wastewater Reclamation District biosolids-application areas near Deer Trail, Colorado, 2007 and 2008. 16

5. Arapahoe County, Colorado, soil- and crop-sampling area.

6. Elbert County, Colorado, soil- and crop-sampling area...

7. Continuous depth-to-water, water-temperature, precipitation, and air-temperature data for well DTX2 near Deer Trail, Colorado, 2007 and 2008

8. Continuous depth-to-water and precipitation data for wells DTX9, DTX10, and DTX11 (a recharge-evaluation site) near Deer Trail, Colorado, 2007 and 2008........20

9. Water-level comparison for the recharge-evaluation site containing wells DTX7, DTX8 near Deer Trail, Colorado, 2007 and 2008.

10. Water-level comparison for the recharge-evaluation site containing wells DTX9, DTX10, and DTX11 near Deer Trail, Colorado, 2007 and 2008.

11. Distribution of groundwater constituent data collected near Deer Trail, Colorado, compared to regulatory standards for selected constituents, 2007 and 2008. .23

12. Groundwater concentrations near Deer Trail, Colorado, for selected constituents, 2007 and 2008.

\section{Tables}

1. Biosolids applications by Metro Wastewater Reclamation District to the study area near Deer Trail, Colorado, 2007 and 2008

2. Methods used to analyze biosolids samples collected at the Metro Wastewater Reclamation District and crop samples collected near Deer Trail, Colorado, 2007 and 2008

3. Chemical data for biosolids samples collected at the Metro Wastewater Reclamation District, 2007 and 2008

4. Quality-control data associated with biosolids samples collected at the Metro Wastewater Reclamation District, 2007 and 2008

5. Plutonium data for biosolids samples collected at the Metro Wastewater Reclamation District, 2007 and 2008

6. Chemical data for crop samples collected near Deer Trail, Colorado, 2007 and 2008....32

7. Selected information for U.S. Geological Survey monitoring wells near Deer Trail, Colorado, 2007 and 2008

8. Methods used to analyze groundwater samples collected near Deer Trail, Colorado, 2007 and 2008

9. Monthly depth-to-water data for U.S. Geological Survey monitoring wells near Deer Trail, Colorado, 2007 and 2008

10. Water-quality data for groundwater samples collected at U.S. Geological Survey monitoring wells near Deer Trail, Colorado, 2007 and 2008. 
11. Quality-control data for blank samples associated with groundwater samples collected near Deer Trail, Colorado, 2007 and 2008.

12. Comparison of water-quality data for groundwater and replicate samples collected near Deer Trail, Colorado, 2007 and 2008.

\section{Conversion Factors, Vertical Datum, and Abbreviations}

\begin{tabular}{lcl}
\hline \multicolumn{1}{c}{ Multiply } & By & \multicolumn{1}{c}{ To obtain } \\
\hline centimeter (cm) & Length & \\
foot (ft) & 0.3937 & inch (in.) \\
inch (in.) & 0.3048 & meter (m) \\
kilometer (km) & 2.54 & centimeter (cm) \\
meter (m) & 0.6214 & mile (mi) \\
micrometer (um) & 3.281 & foot (ft) \\
mile (mi) & 0.00003937 & inch (in.) \\
millimeter (mm) & 1.609 & kilometer (km) \\
\hline & 0.03937 & inch (in.) \\
\hline acre & Area & \\
section (640 acres or 1 square mile) & 0.004047 & square kilometer (km²) \\
square foot (ft $\left.{ }^{2}\right)$ & 259.0 & square hectometer (hm²) \\
square mile (mi $\left.{ }^{2}\right)$ & 0.09290 & square meter ( $\left.{ }^{2}\right)$ \\
\hline & 2.590 & square kilometer (km²) \\
\hline gallon (gal) & Volume & \\
liter (L) & 3.785 & liter (L) \\
ounce, fluid (fl. oz) & 33.82 & ounce, fluid (fl. oz) \\
\hline & 0.02957 & liter (L) \\
\hline gram (g) & Mass & \\
pound, avoirdupois (lb) & 0.03527 & ounce, avoirdupois (oz) \\
ton, short (2,000 lb) & 0.4536 & kilogram (kg) \\
ton, long (2,240 lb) & 0.9072 & megagram (Mg) \\
\hline
\end{tabular}

Temperature in degrees Celsius $\left({ }^{\circ} \mathrm{C}\right)$ may be converted to degrees Fahrenheit $\left({ }^{\circ} \mathrm{F}\right)$ as follows:

$$
{ }^{\circ} \mathrm{F}=\left(1.8 x^{\circ} \mathrm{C}\right)+32
$$

Vertical coordinate information is referenced to the North American Vertical Datum of 1988 (NAVD 88).

Horizontal coordinate information is referenced to the North American Datum of 1983 (NAD 83).

Altitude, as used in this report, refers to distance above the vertical datum.

Specific conductance is given in microsiemens per centimeter at 25 degrees Celsius $\left(\mu \mathrm{S} / \mathrm{cm}\right.$ at $\left.25^{\circ} \mathrm{C}\right)$.

Concentrations of chemical constituents in water are given either in milligrams per liter (mg/L) or micrograms per liter ( $\mu \mathrm{g} / \mathrm{L})$. 



\title{
Biosolids, Crop, and Groundwater Data for a Biosolids- Application Area near Deer Trail, Colorado, 2007 and 2008
}

\author{
By Tracy J.B. Yager, David B. Smith, and James G. Crock
}

\section{Abstract}

During 2007 and 2008, the U.S. Geological Survey monitored the chemical composition of biosolids, crops, and groundwater related to biosolids applications near Deer Trail, Colorado, in cooperation with the Metro Wastewater Reclamation District. This monitoring effort was a continuation of the monitoring program begun in 1999 in cooperation with the Metro Wastewater Reclamation District and the North Kiowa Bijou Groundwater Management District. The monitoring program addressed concerns from the public about potential chemical effects from applications of biosolids to farmland in the area near Deer Trail, Colo. This report presents chemical data from 2007 and 2008 for biosolids, crops, and alluvial and bedrock groundwater. The chemical data include the constituents of highest concern to the public (arsenic, cadmium, copper, lead, mercury, molybdenum, nickel, selenium, zinc, and plutonium) in addition to many other constituents. The groundwater section also includes data for precipitation, air temperature, and depth to groundwater at various groundwater-monitoring sites.

\section{Introduction}

Since 1993, the Metro Wastewater Reclamation District (Metro District) has been applying biosolids generated from municipal sewage treatment in Denver, Colo., to their property near Deer Trail, Colo. (figs. 1 and 2; these figures and all other figures and tables are located in the Data Section at the back of the report). The biosolids are trucked about 75 miles (mi) east from Denver to the Metro District property (fig. 2) and are applied to nonirrigated farmland. The first property the Metro District acquired near Deer Trail was about 15 square miles (mi $)$ (fig. 3). In 1995, the Metro District traded some of the property and acquired additional property in the same area. The resulting boundaries of the original property became known as the Metro District central property (fig. 2). The new properties consisted of about $14.5 \mathrm{mi}^{2}$, known as the north property, and about $50 \mathrm{mi}^{2}$, known as the south property (fig. 2). In 1999, the three Metro District properties together (known as the METROGRO Farm) encompassed almost
$70 \mathrm{mi}^{2}$ of farmland in Arapahoe and Elbert Counties. The three Metro District properties and surrounding private property are considered the study area for this report (fig. 2).

\section{Description of Study Area}

The study area is located on the eastern plains of Colorado about $10 \mathrm{mi}$ east of Deer Trail (fig.1). The study area is on the eastern margin of the Denver Basin, a bowl-shaped sequence of Cretaceous sedimentary rocks that was formed in an ocean or near-ocean environment. The geology of the study area consists of interbedded shale, siltstone, and sandstone, which may be overlain by clay, windblown silt and sand, or alluvial sand and gravel (Sharps, 1980; Major and others, 1983; Robson and Banta, 1995). The primary water-supply aquifer is the Laramie-Fox Hills aquifer, which is a bedrock aquifer that ranges from 0 to about 200 feet (ft) thick in the study area and is the bottom aquifer in the Denver Basin aquifer sequence (Robson and others, 1981; Robson and Banta, 1995; Yager and Arnold, 2003). Multiple alluvial aquifers are present in the study area. These aquifers are associated with the surficial drainage network and contain water of variable quality, are of limited extent, and generally yield little water (Stevens and others, 2003; Yager and Arnold, 2003).

The study area is within the South Platte River drainage basin; all streams in this area drain northward to the South Platte River (fig. 1; U.S. Geological Survey, 1974; Seaber and others, 1987; Yager and Arnold, 2003). Short segments of some of the streams are intermittent, but in general, the streams are ephemeral and flow only after storms. No surface water flows off the Metro District properties except after storms. Most ponds in the area have been created by detention structures. Soils in the area generally are sandy or loamy on flood plains and stream terraces, clayey to loamy on gently sloping to rolling uplands, and sandy and shaley on steeper uplands (Larsen and others, 1966; Larsen and Brown, 1971).

Land use in the study area was historically rangeland or cropland and pasture (U.S. Geological Survey, 1980). Some petroleum exploration was done in the area (Drew and others, 1979), but no oil or gas exploration or production took place on the Metro District properties during 2007 and 2008 (N. Crews, Metro Wastewater Reclamation District, written commun., April 13, 2011). Land in the study area 
was used as rangeland or cropland during 2007 and 2008. Cattle and sheep were the primary domesticated animals grazing the area, and wheat was the primary crop. Farmland was not irrigated. Herbicides and other chemicals were applied to the study area during 2007 and 2008 for farming purposes. Pesticides and other fertilizers also may have been applied to the Metro District properties historically, but little information is available about these historical applications.

Biosolids were applied as a fertilizer only on the Metro District properties.

Biosolids are applied by the Metro District to their properties near Deer Trail (figs. 2-4) according to agronomic loading rates (table 1; Colorado Department of Public Health and Environment, 2003). Land-applied biosolids must meet Colorado regulatory limits (Colorado Department of Public Health and Environment, 2003); otherwise, agronomic loading rates could be exceeded and soils could become overloaded. Soil quality either can be improved by biosolids applications through increased nutrients and organic matter or degraded through accumulation of excessive nutrients, metals, or other chemical constituents. Animal waste (related to wildlife and grazing domestic livestock) and applications of pesticides and fertilizers (organic and inorganic) can affect soil and water quality (Adeyinka and Mustapha, 2005) and therefore can affect crops, dust, groundwater and surface-water quality, and streambed-sediment chemistry.

\section{Monitoring History}

The U.S. Geological Survey (USGS) has collected data in the study area since 1993. From 1993 to 1999, the USGS, in cooperation with the Metro District, monitored the quality of shallow groundwater on the original Metro District property (fig. 3). Public concern about applications of biosolids to farmland increased in the late 1990s after the Metro District agreed to accept treated groundwater from the Lowry Landfill Superfund site in Denver. The concern was that water from the Lowry Superfund site might contain radionuclides that would contaminate the Metro District biosolids and the study area. In January 1999, the USGS began an expanded monitoring program for 1999 through 2003, in cooperation with the Metro District and the North Kiowa Bijou Groundwater Management District, to address this and other concerns from stakeholders. A subsequent phase of the expanded monitoring program near Deer Trail continued with selected monitoring from 2005 through 2010. Conclusions from the 1999-2003 phase (Yager and others, 2004d) were used to determine monitoring components, analytes, sites, and frequency for the 2005-2010 phase. The USGS refers to the 1999-2003 monitoring program and subsequent USGS monitoring efforts in the study area as the "expanded monitoring program."

The expanded monitoring program near Deer Trail is distinct from, but built on, the first USGS monitoring program near Deer Trail on the Metro District central property (fig. 3; 1993-1999). Compared to the previous program, the expanded program includes a larger study area (fig. 2; all three Metro District properties and private-property locations), more monitoring components (biosolids, soil, crops, and streambed sediments were monitored in addition to groundwater), a more comprehensive list of chemical constituents, expanded statistical analyses of data, and an extended monitoring period (1999-2010). In 2005, the monitoring program was further expanded to include analysis of nitrogen isotopes and organic wastewater compounds in biosolids, biosolids leachates, and groundwater. A monitoring component to characterize dust was included for 2006-2007.

The USGS is doing both the original and expanded monitoring programs in cooperation with the Metro District. Both programs were designed, conducted, and interpreted independently by the USGS, and quality-assured USGS data and reports were released to the public and the Metro District at the same time. Selected monitoring results for 1993 through 1999 and a detailed discussion of hydrogeology of the study area are reported by Yager and Arnold (2003). Monitoring results for 1999 were reported by Stevens and others (2003). Monitoring results for 2000 were reported by Yager and others (2004a). Monitoring results for 2001 were reported by Yager and others (2004b). Monitoring results for 2002 through 2003 were reported by Yager and others (2004c). Monitoring results for 2004 through 2006 were reported by Yager and others (2009). Interpretive information for the 1999 through 2003 data was reported by Yager and others (2004d). Data and interpretations for the dust-monitoring component were reported by Reheis and others (2009). Additional chemical data were reported by Crock and others (2008a, 2008b, 2009a, 2009b, and 2010). Selected data for 1999 through 2008 also were published in the "USGS Expanded Monitoring Program near Deer Trail" progress reports (http://co.water.usgs.gov/projects/CO406/ pubsprogress.html accessed February 8, 2011).

The expanded monitoring program near Deer Trail addressed concerns about the effects of biosolids applications and other agricultural activities on the environment and increased scientific insight about Denver Basin hydrology. The objectives of this USGS program were to (1) evaluate the combined effects of biosolids applications, land use, and natural processes on soils, crops, dust, the bedrock aquifer, alluvial aquifers, and streambed sediments by comparing chemical data to (a) regulatory standards, (b) data from a site where biosolids are not applied (a control site), or (c) earlier data from the same site (trends); (2) monitor biosolids for trace elements and radioactivity and compare trace-element concentrations and radioactivity with regulatory standards; and (3) characterize the hydrology of the study area. The monitoring of each component (such as crops or groundwater) was a stand-alone study that did not necessarily encompass the entire study area. More detailed information about the monitoring of each component is included later in this report. 


\section{Purpose and Scope}

The purpose of this report is to present data from the expanded monitoring program near Deer Trail for January 2007 through December 2008. This report presents data for all monitoring components of the program for which data were collected during 2007 and 2008, except the dust component. The report includes information for biosolids, crops, and alluvial-aquifer and bedrock-aquifer groundwater. The groundwater section includes hydrologic data (precipitation, air temperature, and depth to groundwater) and water-quality data (chemistry and field measurements). Data in this report were collected by the USGS after the water transfer from the Lowry Landfill Superfund site to the Metro District plant, which began in July 2000.

This report does not include any statistical comparisons of data to regulatory standards or calculation of trends; plans are to include statistical testing of the data in an interpretive report for the 2004-2010 data prepared after 2010. This report does not include any dust data, organic wastewatercompound data, or isotope data collected during 2007 and 2008 for any monitoring component; plans are to include these data with interpretive information in separate reports. No description, data, or discussion of the soil and streambedsediment monitoring components are included in this report because no data for these components were collected during 2007 and 2008.

This report is organized by monitoring component because each component is monitored as a separate study. For each monitoring component, the specific objectives, approach, data, and a discussion are included in this report.

\section{Biosolids}

Biosolids are solid organic matter recovered from a sewage-treatment process that meets State and Federal regulatory criteria for beneficial use, such as for fertilizer. The regulatory limits for Colorado biosolids are described by Colorado Department of Public Health and Environment (2003) as Table 1 Ceiling Concentration Limits and Table 3 Pollutant Concentration Limits. Table 3 Pollutant Concentration Limits (formerly known as Grade I) are more restrictive than Table 1 Ceiling Concentration Limits (formerly known as Grade II). In this report, "Table 3 biosolids" and "Table 3 Class B biosolids" mean biosolids that meet the criteria in Table 3 of the Colorado biosolids regulation. Land-applied biosolids must meet or exceed Table 1, Class B criteria (Colorado Department of Public Health and Environment, 2003). The Metro District applies Table 3 Class B biosolids to their properties near Deer Trail. The biosolids-application areas, dates of application, and application rates provided by the Metro District for their properties near Deer Trail are listed in table 1 of this report; application areas (called "Destination Codes" [DC]) are shown in figure 4.

\section{Objectives of Monitoring Biosolids}

The biosolids must meet regulatory standards for trace elements. Exceeding these standards could adversely affect the quality of soil on which the biosolids are applied and could alter the Metro District plans for the application of biosolids in Arapahoe and Elbert Counties. The composition of biosolids was monitored to provide an independently determined data set against which the Metro District chemical analyses and the regulatory standards for biosolids can be compared. The data also will constitute a chemical baseline against which any future change in the concentration of constituents analyzed for in this study may be recognized, measured, and compared.

\section{Approach for Monitoring Biosolids}

Biosolids samples were collected directly from the Metro District facility in Denver rather than from individual trucks or fields near Deer Trail to enable the USGS to obtain a more representative sample. Biosolids samples were analyzed for concentrations of arsenic, cadmium, copper, lead, mercury, molybdenum, nickel, selenium, sulfur, zinc, and plutonium. The concentrations in the samples were compared to applicable Colorado standards for biosolids (Colorado Department of Public Health and Environment, 2003).

\section{Sampling Methods for Biosolids}

In 2007 and 2008, the USGS received biosolids samples monthly from the Metro District. Each monthly sample was a composite bottled over 1-2 days at the Metro District wastewater treatment plant in Denver by Metro District personnel. Biosolids samples were collected in acid-washed, rinsed, 1-gallon (gal) plastic or glass bottles. The USGS received one to two bottles from each centrifuge that was active at the treatment plant at the time the sample was collected; the treatment plant had a maximum of four centrifuges active at any time. The USGS combined the contents of all sample bottles into a plastic tray and dried the resulting composited sample in a fume hood in the laboratory. Samples for trace-element or radioactivity analyses were dried under an infrared heat lamp to decrease drying time. When the biosolids sample was dried, an aliquot was removed and ground to less than 150 micro-meters $(\mu \mathrm{m})$ for chemical analysis. The remaining dried biosolids sample was archived as a single monthly sample.

\section{Analytical Methods for Biosolids}

The monthly biosolids samples were processed and analyzed for trace elements at the USGS Mineral Resources Program laboratories (MRPL) in Denver. A single, randomly selected biosolids sample was analyzed each year for radioactivity through a contract with the USGS National Water Quality Laboratory (NWQL) at Eberline Services in California. The methods used to analyze the biosolids for each constituent are listed in table 2 . 


\section{Quality Assurance for Biosolids}

The purpose of the quality-assurance program developed for the biosolids monitoring component was to ensure that the analytical results were within acceptable limits of both precision (the reproducibility of results) and accuracy (the degree of conformity of results for a sample having known concentrations). The precision was determined by analyzing the same biosolids sample multiple times, and accuracy was determined by analyzing a National Institute of Standards and Technology (NIST) standard reference material (SRM). The SRM 2781, a domestic sewage sludge, was prepared by NIST from material collected at the Metro District treatment plant in Denver. The SRM 2781 has been analyzed extensively by many laboratories throughout the world, and the NIST has certified an acceptable range of values for various constituents in the SRM. The constituents include those of interest in this study. Each biosolids sample was submitted to the laboratories with a sample of the SRM. If the analytical results for the constituent of interest in the SRM were within the acceptable range, the results for the biosolids samples were accepted. Additional quality-assurance information for the 2007 and 2008 biosolids samples is provided by Crock and others (2008b and 2009a). The analytical quality-assurance practices and procedures of the MRPL are described by Taggart (2002).

\section{Biosolids Data}

Data for trace-element concentrations in the 2007 and 2008 biosolids samples are listed in table 3 of this report along with the Colorado standards (Table 1 Ceiling Concentration Limits and Table 3 Pollutant Concentration Limits) for landapplied biosolids. Quality-control data (NIST SRM 2781) associated with the biosolids samples are listed in table 4. Data for plutonium concentrations in the 2007 and 2008 biosolids samples are listed in table 5.

\section{Discussion of Biosolids Data}

All trace-element concentrations in the biosolids samples were less than the Colorado standards established by the Table 1 Ceiling Concentration Limits and Table 3 Pollutant Concentration Limits (Colorado Department of Public Health and Environment, 2003). No plutonium standards are applicable to the biosolids. The plutonium data for biosolids (table 5) are similar to the plutonium data for soil in the study area (Stevens and others, 2003; Yager and others, 2004b). The radioactivity data are reported in the uncensored form as received from the laboratory rather than censored by either the contract or calculated minimum detectable concentration (MDC). Relative to the censored form (data reported as less than the MDC), the uncensored form provides more information about the uncertainty and the very small concentrations of plutonium. The negative activity concentrations reported in table 5 mean the sample count was less than the laboratory background count for that day. Radioactivity data are produced from instruments that detect radioactive decay (disintegrations) in a sample as counts per minute. The background count was subtracted from the sample count, and the resulting value was converted to activity-concentration units of picocuries per gram.

\section{Crops}

As previously mentioned, biosolids can contain elevated concentrations of certain trace elements. The application of biosolids to farmland on which grain crops are grown that eventually will be consumed by animals or humans has led to public concern about the composition of the crops grown on the fields receiving biosolids.

\section{Objectives of Monitoring Crops}

Crops are monitored for trace elements to establish independent chemical data sets for the composition of the crops before and after the application of biosolids. The data will enable the USGS to recognize and quantify significant changes in the chemical composition of crops caused by the application of biosolids to agricultural soils or by other natural or human-induced processes.

\section{Approach for Monitoring Crops}

In the summer of 2000, the USGS began monitoring crops grown in the same two areas where soils were monitored (figs. 2, 5, and 6). Each of the two soil- and crop-monitoring areas included one field that received biosolids and two fields that did not receive biosolids and are used as "control" fields to determine the natural variability of soil and crop composition for the duration of the study (figs. 5-6). The fields at each area are farmed in a way similar to the rest of the Metro District property and have crops planted and harvested approximately every other year. Soils from each of the six fields were sampled in 1999 before biosolids were applied to the two center fields and were sampled again after each harvest through 2003. Crop samples are collected from every harvest, which is in summer.

The primary crop monitored is winter wheat, although millet and corn also have been grown and sampled. The primary form of the crop that is monitored is mature grain at the time of harvest. Crops grown on fields that receive biosolids applications are monitored along with crops grown on fields that do not receive biosolids applications. The crops from fields that do not receive biosolids applications are used as a reference for comparison. Crop samples were obtained from the monitoring areas in 2000, 2001, 2002, 2004, 2006, and 2008. The crop samples were analyzed for arsenic, cadmium, copper, lead, mercury, molybdenum, nickel, and zinc. During 2003, 2005, and 2007, no crops were grown in either the 
Arapahoe or Elbert County soil- and crop-monitoring areas. Data will be compared after each sampling and at the conclusion of the study to determine how the concentrations of the constituents of interest vary with time.

\section{Site Selection for Monitoring Crops}

The two soil- and crop-monitoring areas were selected in 1999 on the basis of Metro District land that was eligible for biosolids application but where biosolids had never been applied. One area was selected on the Metro District's north property in Arapahoe County, and one area was selected on the Metro District's south property in Elbert County (fig. 2). The Arapahoe County area is located in Township 4 South, Range 58 West, Section 22 and lies about 0.25 mi west of Badger Creek (fig. 5). The Elbert County area is located in Township 6 South, Range 57 West, Section 8 and lies immediately west of Beaver Creek (fig. 6). Each of the two soil- and crop-monitoring areas consist of three 20 -acre (933-ft by 933-ft) fields separated by 100-ft buffer strips (figs. 5 and 6). When samples could not be obtained from a designated soiland crop-monitoring area (such as in the case of crop failure), a sample from a nearby biosolids-applied field was analyzed when possible.

\section{Sampling Methods for Crops}

During 2007 and 2008, the crop sample was collected by the Metro District from the machine-harvested and threshed grain obtained from each field. The combine was emptied before harvesting grain from any of the soil- and crop-monitoring fields to ensure that the grain sampled was from only the designated field; no grain from the buffer strips (figs. 5) was included in the wheat-grain sample. The grain harvested from each designated field was collected by hand from the combine hopper about every 100-200 ft of the entire field and composited into a clean bucket. Samples of mature, field-dried wheat grain and corn kernels were provided to the USGS by the Metro District in clean, white, plastic buckets. The USGS received a single, separate, composited crop sample from each of the 20-acre fields harvested (fig. 5) and from an Elbert County biosolids-applied field (fig. 4, DC 454).

\section{Analytical Methods for Crops}

The crop samples were processed and analyzed for trace elements at the USGS MRPL in Denver. The crop samples were dried under forced air at room temperature and then cleaned using forced air and sieving. The cleaned crop samples were ground to a flour using a commercial table-top grain mill. A split of each ground sample was ashed in a forced-air muffle furnace at $500^{\circ} \mathrm{C}$. The ashed grain samples and the dried, unashed grain samples were analyzed by the protocols described in detail by Yager and others (2004a). The 2008 crop samples were analyzed for arsenic, cadmium, copper, lead, mercury, molybdenum, nickel, and zinc. The analytical methods are summarized in table 2 . The analytical qualityassurance practices and procedures of the MRPL are described by Taggart (2002).

\section{Crop Data}

In 2008, wheat grain was sampled from the Arapahoe County soil- and crop-monitoring area (fig. 5), and corn kernels were sampled from a biosolids-applied field (DC 454; fig. 4) in Elbert County. Chemical data for the Arapahoe County wheat grain and the Elbert County corn kernels are listed in table 6. No data are available for selenium or sulfur concentration in the 2008 crop samples.

\section{Discussion of Crop Data}

All analyses of crop samples met the quality-assurance criteria described by Taggart (2002). The chemical differences between wheat collected from the 20-acre field to which biosolids have been applied and wheat from the control fields where no biosolids have been applied are minimal. Fluctuations in wheat-grain concentration among the 2008 samples are within the normal range of uncertainty associated with the method.

Only one crop cycle took place during the 2007-2008 monitoring period so only one sample was collected from each monitored field. Each sample was a composite from across the entire field, so the single sample is representative of the entire field. Collecting additional composite samples from the same field could have provided information about concentration variability within a field but would not have increased sample representativeness.

Few comparisons can be made between the grain sample of Elbert County relative to the grain samples of Arapahoe County because the Elbert County sample was corn and the Arapahoe County samples were wheat, and because the Elbert County sample was not collected from the soil- and cropmonitoring area. The 2008 corn-kernel sample from the Elbert County biosolids-applied field had smaller concentrations of cadmium, copper, molybdenum, and nickel than the 2008 samples of wheat from the Arapahoe County fields (table 6) and than the 2006 sample of corn kernels from Elbert County (Yager and others, 2009).

\section{Groundwater}

Applications of pesticides, herbicides, or fertilizers (including biosolids) to the land surface can affect the quality of shallow groundwater directly by contaminating recharge water at the surface or during infiltration through contaminated soils or sediments (remobilization). These applications also can affect the quality of shallow groundwater indirectly by contributing to natural processes such as nitrification. 
Discharge from contaminated alluvial groundwater also could contaminate surface water (ponds or streams) or bedrock water-supply aquifers. For this report, alluvial groundwater is defined as the water contained in subsurface, unconsolidated (uncemented), wind- or water-transported sediments in current or historical stream channels or flood plains. Bedrock groundwater is defined as the water contained in the fractures or pore spaces of the rock (consolidated sediments) that underlies soil or other uncemented materials; the primary bedrock aquifer in the study area is the Laramie-Fox Hills aquifer (Robson and Banta, 1995).

\section{Objectives of Monitoring Groundwater}

Groundwater was monitored to characterize the hydrology and water quality of the aquifers; to determine if concentrations of nitrate, arsenic, cadmium, chromium, copper, lead, mercury, molybdenum, nickel, selenium, and zinc in the groundwater are significantly greater than regulatory standards; and to determine if concentrations of these constituents are increasing with time in groundwater at or near the Metro District properties.

\section{Approach for Monitoring Groundwater}

Alluvial and bedrock groundwater was monitored during 2007 and 2008 at USGS monitoring wells in the study area that were installed in 1993-2002 during previous phases of monitoring. "D"-numbered wells were drilled before 1999 as part of the first monitoring program (except for wells D6A and D25A, which were drilled in 2002), and "DTX"-numbered wells were drilled in 1999 or 2000 (fig. 2). Lithologic and well-completion information for these well locations are provided by Stevens and others (2003), Yager and Arnold (2003), and Yager and others (2004a). During 2007 and 2008, fewer groundwater sites were monitored routinely than during 1999 through 2003 , but all the USGS monitoring wells remaining in the study area (figs. 2 and 3) were visited at least once. Selected information for all the USGS wells monitored during 2007 and 2008 as part of this program is summarized in table 7 .

To characterize hydrology, semi-quantitative meteorologic (precipitation and air temperature) data were collected, depth to groundwater was measured monthly, and groundwater altitude was compared at two recharge-evaluation sites. Each recharge-evaluation site consisted of a nested bedrock-aquifer well paired with an alluvial-aquifer well at the same location. Monitoring multiple wells in the same location enabled different zones of groundwater to be monitored without having to consider spatial variability and can enable inferences about vertical directions of groundwater flow between zones. In this study, a nested well consists of a single borehole that has two separate piezometers screened at two separate zones; the shallow zone is designated by " $\mathrm{A}$ " and the deep zone is designated by "B" after the well name. Therefore, three different aquifer zones are monitored at each of the two recharge-evaluation sites in Muddy Creek downgradient from the Metro District properties in the northwest part of the study area (fig. 2). A fourth aquifer zone (well DTX11) is monitored at the DTX9 recharge site to provide information about a deeper coarsegrained part of the Muddy Creek alluvial aquifer than is monitored by well DTX9.

To provide detailed information about groundwater hydrology in the study area, electronic equipment (commonly referred to as continuous-recorder equipment) was used at selected well sites. In 2000, electronic data-logger (EDL) equipment was installed at the DTX9/DTX10/DTX11 site to automatically report hourly measurements of cumulative precipitation and instantaneous depth to groundwater. In 2007, this continuous-recorder equipment was upgraded to a data-collection platform (DCP) to transmit the data by satellite into the USGS database. In November 2008, the continuous-recorder equipment again was upgraded, and data collection at 15-minute intervals began. DCPs have been used to collect hourly data at various other locations in the study area (DTX2, DTX5, and D25). However, the recorders were discontinued at wells D25 and DTX5 during 2004 through 2006 and at well DTX2 during 2007 through 2008. During 2007 and 2008, all the study-area DCP data usually were available on the Internet. The data generated from the continuous-recorder equipment is called "continuous data" because the recording equipment runs continuously and records data frequently (hourly or more often).

To characterize water quality of the alluvial aquifers, samples were collected quarterly from five sites. To characterize water quality of the bedrock aquifer, a sample was collected annually from two sites. Other USGS monitoring wells in the study area also were sampled at least once during 2007 through 2008 to provide additional information about groundwater-quality changes in the study area after biosolids applications began. Groundwater samples were analyzed for physical properties, dissolved major ions and trace elements, and dissolved and total nutrients. Analyses included nitrate, arsenic, cadmium, copper, chromium, lead, mercury, molybdenum, nickel, selenium, and zinc (constituents considered the most important by the stakeholders). Selected analytical data are compared to the Colorado standards (Colorado Department of Public Health and Environment, 2004) annually.

All groundwater data are maintained in the USGS National Water Information System (NWIS) data base. All groundwater data collected for this program during 1999 through 2006 and corresponding interpretive information were published in USGS reports (Stevens and others, 2003; Yager and Arnold, 2003; Yager and others, 2004a, 2004b, 2004c, 2004d, and 2009) and are available on the Internet (http://co.water.usgs.gov/projects/CO406/pubs.html accessed February 8, 2011).

\section{Site Selection for Monitoring Groundwater}

Site selection for routine groundwater monitoring during 2007 and 2008 was the same as that for 2005 and 2006, which is described in detail by Yager and others (2009). Depth to 
water was usually measured at all USGS monitoring wells shown in figure 2 . Groundwater was routinely sampled at five alluvial property-boundary wells (DTX1, DTX2, D6, D17, and D25) and at the shallowest zones of the bedrock aquifer at two locations (DTX8A and DTX10A) (fig. 2). Recharge interactions were monitored at the two recharge-evaluation sites in the northwest part of the study area, each of which included at least one alluvial-aquifer well and one nested bedrock-aquifer well. Wells DTX7 and DTX8 compose one recharge-evaluation site, and wells DTX9, DTX10, and DTX11 compose the other recharge-evaluation site (fig. 2).

As many as 10 years had elapsed since the other, older USGS monitoring wells in the vicinity (fig. 3) had been visited. In 2007, all USGS monitoring wells remaining in the vicinity of the Metro District property (figs. 2 and 3) were visited, and depth to water was measured. Subsequently, all USGS monitoring wells in the vicinity (figs. 2 and 3 ) were sampled for inorganic water quality during 2007 or 2008 if in good condition and yielding sufficient water for a complete sample. Wells sampled as part of this decadal sampling effort were DTX5, DTX6, D3, D4, D5, D6A, D7, D8, D10, D13, D14, D15, D16, D19, D20, D21, D22, D23, D25A, D26, D27, D28, D31, D32, and D33 (figs. 2 and 3). Information about all the USGS monitoring wells shown in figures 2 and 3 is listed in table 7.

Sites for continuous-recorder equipment were selected to provide detailed data for evaluating complex or changing interactions. During 2007 and 2008, the interactions between various aquifers and groundwater zones and weather variables were of most interest at the location containing wells DTX9, DTX10, and DTX11 (fig. 2). This location is the nearest recharge-evaluation site downstream from the Metro District property near Deer Trail and is a location where two distinct zones of alluvial aquifer are present above the bedrock aquifer at an ephemeral stream (Stevens and others, 2003; Yager and others, 2004a). Therefore, continuous-recorder equipment was used at the DTX9/DTX10/DTX11 site to collect detailed data in 2007 and 2008. Sufficient detailed data were collected during 1999-2007 at well DTX2 (fig. 2), so the DCP equipment was removed from DTX2 during 2007 through 2008.

\section{Sampling Methods for Groundwater}

All data-collection methods used during 2007 and 2008 were the same as the 1999 methods, which are detailed by U.S. Geological Survey (variously dated) and Stevens and others (2003). Monthly depth-to-water measurements were made using a vinyl-coated electric tape. Data from the DCPs automatically were recorded hourly and were checked against the manually measured monthly data.

Water-quality samples were collected using standard USGS methods (Horowitz and others, 1994; U.S. Geological Survey, variously dated). Water levels and field measurements such as $\mathrm{pH}$ and specific conductance were recorded with the collection of each groundwater sample. Blank and replicate samples were analyzed to evaluate bias and variability of the groundwater data. All sampling equipment was used exclusively by the USGS and was used only in the study area to prevent cross contamination from other sites in other study areas. All samples and sampling equipment were thoroughly cleaned between sampling events and retained at all times in the custody of the USGS in secured facilities.

\section{Analytical Methods for Groundwater}

Groundwater samples were analyzed by the USGS NWQL in Denver. The methods used to analyze the 2007 and 2008 groundwater samples are listed in table 8, which includes laboratory Minimum Reporting Levels (MRLs) for the constituents of interest.

\section{Quality Assurance for Groundwater}

Quality-assurance procedures were implemented during the course of the monitoring program to ensure the quality of the data. Procedures were implemented for depth-to-water measurements, DCP-data collection, groundwater-sampling preparation, field-properties measurements, groundwater sampling, and laboratory analysis. Replicate and blank water-quality samples were collected every sampling trip and analyzed for the same constituents and properties as were the environmental groundwater samples. Additional blank samples occasionally were collected for specific topical quality-assurance purposes and therefore were analyzed only for selected constituents and properties. Quality-assurance procedures are detailed in the 1999 data report (Stevens and others, 2003). The analytical quality-assurance practices and procedures of the NWQL are described by Friedman and Erdmann (1982).

\section{Groundwater Data}

Monitoring at groundwater sites during 2007 and 2008 produced hydrologic and water-quality data. Hydrologic data included cumulative measurements of precipitation at two sites and instantaneous measurements of hourly air temperature at one site, hourly water temperature at one well, hourly depth to water at four wells, and monthly depth to water at all wells. Water-quality data included analytical results from quarterly or annual sampling, as well as data from a single sampling of 25 monitoring wells.

\section{Hydrologic Data}

Hourly precipitation and air-temperature data were collected from the study area during 2007 and 2008. Cumulative precipitation and instantaneous air temperature recorded hourly during 2007 and 2008 at well DTX2 are shown in figure 7. Cumulative precipitation recorded hourly during 2007 and 2008 at the DTX9/DTX10/DTX11 site are shown in figure 8. 
Monthly depth-to-water data and hourly depth-to-water and water-temperature data were collected from the study area during 2007 and 2008. The monthly depth-to-water data for the USGS monitoring wells are listed as measurements below the measuring point at a specific time (table 9) to show the maximum precision of the measurements. The measuring point for the USGS monitoring wells generally was about 2-3 ft above land surface (table 7), although land surface fluctuates over time relative to the fixed measuring points and was not remeasured after well installation. Continuous, daily data derived from hourly depth-to-water data for the two DCP sites (DTX2 and DTX9/DTX10/DTX11; fig. 2) are shown in figures 7 and 8 as daily maximum depth to water below land surface. Daily data derived from hourly water-temperature data for DTX2 also are shown in figure 7. No continuous depth-to-water data were collected at wells DTX5 or D25 during 2007 and 2008 because equipment was removed from these sites prior to 2007 .

Water-level data can indicate groundwater recharge information. Water-level altitudes for the paired alluvial-aquifer and bedrock-aquifer wells at the northernmost recharge-evaluation site (wells DTX7 and DTX8) are compared for 2007 and 2008 in figure 9. Water-level altitudes for the paired alluvial-aquifer and bedrock-aquifer wells at the other recharge-evaluation site (wells DTX9, DTX10, and DTX11) are compared for 2007 and 2008 in figure 10.

\section{Water-Quality Data}

Water-quality data for groundwater samples collected from the study area during 2007 and 2008 are listed in table 10. Data are included for field properties, physical properties, major ions, nutrients, and trace elements for 32 USGS monitoring wells in the study area, including the bedrock-aquifer wells at the recharge-evaluation sites. Graphs of selected groundwater-quality data are provided in figures 11 and 12. Quality-control water-quality data for the blank samples are listed in table 11, and comparison data for groundwater and replicate samples are listed in table 12.

\section{Discussion of Groundwater Data}

The precipitation and air-temperature data collected during 2007 and 2008 (figs. 7 and 8) are semi-quantitative. These data were checked by manual measurements when possible during monthly site visits. The tipping-bucket rain gages (the part of the continuous-recorder equipment used to measure precipitation) were deployed throughout the year, but are known to under-report precipitation during winter months. Precipitation data for all months of 2007 and 2008 are included in figures 7 and 8 , but the precipitation data for winter months are best used for general indication of magnitude and timing of precipitation in the area. The air-temperature data are accurate to within several degrees year round. The checks indicate that these data for
2007 and 2008 are acceptable for the intended purpose of evaluating the response of groundwater to changes in air temperature and precipitation.

Depth-to-water data (table 9) indicate that water levels fluctuated at most wells during 2007 and 2008. At wells DTX4, DTX5, DTX6, D25, and D25A (fig. 2), water levels generally declined after a spring 2007 recharge period. The water level in well DTX4 was in or above the screened interval during all of 2007 and 2008 (table 9) following substantial recharge that began in late May 2006 (Yager and others, 2009); this well usually was dry October 2001 through April 2006 (Yager and others 2004b, 2004c, and 2009). At a few wells (D11a and D19), no spring 2007 recharge was apparent and water levels generally decreased during 2007 and 2008 (table 9). Water levels generally increased during 2008 at DTX2. Although well DTX3 recharged substantially in 2006 for the first time since 2001 (Yager and others, 2004b, 2004c, and 2009), this well remained dry throughout 2007 and 2008 (table 9).

Hydrologic interactions between alluvial and bedrock aquifers can be inferred using water-level data for the same point in time for wells at the same site (figs. 9 and 10). The direction of the vertical movement of groundwater, or the recharge direction, may be indicated by noting that water moves from areas of high hydraulic head (high water-level altitude) to areas of low hydraulic head (low water-level altitude).

The data included in this report indicate that alluvial- and bedrock-aquifer chemistry is variable in space (from site to site) and in time (from one data-collection time to the next at the same site) in the study area (table 10). The distribution of concentrations at each routinely monitored well for selected constituents during 2007 and 2008 is compared to Colorado regulatory standards (Colorado Department of Public Health and Environment, 2004) in figure 11. Time-series graphs (concentration plotted with time) of selected constituents for selected wells are included as figure 12. All concentrations of nitrite plus nitrate as nitrogen at well D6 were greater than the Colorado Human Health standard (fig. 11), but concentrations did not increase markedly with time during 2007 and 2008 (fig. 12). All concentrations of dissolved selenium at well D6 were greater than the Colorado Agricultural and Human Health standards (fig. 11). Concentrations for most constituents in water samples from well D6A in 2007 and 2008 were similar to those of well D6 (table 10). Concentrations of nitrite plus nitrate as nitrogen in wells D7, D10, D26, D27, D28, and D32 also were greater than the Colorado Human Health standard of $10 \mu \mathrm{g} / \mathrm{L}$ (table 10). Concentrations of selenium in wells D3 and D33 also exceeded the Colorado Agricultural standard $(20 \mu \mathrm{g} / \mathrm{L})$ or Human Health standard $(50 \mu \mathrm{g} / \mathrm{L})$ (table 10). Arsenic concentration in the sample from well D21 exceeded the Colorado Human Health standard of $10 \mu \mathrm{g} / \mathrm{L}$ (table 10). During 2007 and 2008, concentrations of nitrate, arsenic, cadmium, chromium, copper, lead, mercury, molybdenum, nickel, selenium, and zinc in samples from the other wells sampled all were less than regulatory standards (table 10 and fig. 11). 
Blank samples were analyzed to evaluate high bias in the low concentration range, which can indicate contamination of field or laboratory supplies or equipment. Concentrations for the blank water-quality samples (table 11) generally indicate little or no contamination bias in the low concentration range for the 2007 and 2008 environmental samples. Only a slight high bias in the low-concentration range is indicated for some major- and trace-element concentrations. The blank samples of type "Q" (table 11) were from the submersible stainless steel pump, and these data indicate occasional slight contamination bias for aluminum, boron, cobalt, copper, lead, nickel, silver, and zinc values in June 2008. This pump was used only at wells DTX8A and DTX10A so only samples from these wells may have been affected, but not substantially. The field blank from September 26, 2008, showed uncharacteristic high bias in the low-concentration range for calcium, magnesium, aluminum, manganese, nickel, strontium, and zinc when an insufficiently cleaned sampling tube was used to prepare the blank sample; this high bias only affected concentration data from the one-time sampling of the older USGS monitoring wells (fig. 3), but not substantially. In general, concentrations for the blank samples were much less than those for the groundwater samples.

The relative percent differences (RPD) between the groundwater samples and the replicate samples were computed to summarize sample variability (table 12). Most of the larger RPDs are due to values or concentrations near the MRL where precision is expected to be poor. In these instances, concentrations may vary little but result in large RPDs. For example, a groundwater sample concentration of $0.04 \mathrm{mg} / \mathrm{L}$ and a replicate-sample concentration of $0.03 \mathrm{mg} / \mathrm{L}$ results in an RPD of 29 percent, but the difference is considered to be within the precision of the method at that concentration. Variability in the data was highest for analyses of arsenic, barium, copper, manganese, nickel, and selenium, although rerun analyses improved RPDs for some of these constituents in table 12 . Note that most if not all of this variability likely is from the analyses and is not inherently present in the groundwater or contributed through field processing. The analytical-method interference that likely caused much of the variability reported for the 2004 through 2006 data (Yager and others, 2009) became markedly better in 2007 and was no longer an issue in 2008. The replicate-sample data indicate generally reproducible analytical results.

\section{Acknowledgments}

The USGS would like to thank all private landowners for allowing access to their properties for data collection. The USGS would especially like to thank the Price, Turecek, and Weisensee families and the Metro District for allowing USGS well or instrument installations on their property.

\section{References Cited}

Adeyinka, J.S., and Mustapha, R., 2005, An assessment of pollution from agrochemical application: International Journal of Environmental Studies, v. 62, no. 3, p. 323-327.

American Public Health Association, 1998, Standard methods for the examination of water and wastewater $\left(20^{\text {th }} \mathrm{ed}\right.$.): Washington, D.C., American Public Health Association, American Water Works Association, and Water Environment Federation, p. 3-37-3-43.

Brown, Z.A., and Curry, K.J., 2002, Total sulfur by combustion, Chapter Q, of Taggart, J.E., Jr., ed., 2002, Analytical methods for chemical analysis of geological and other materials, U.S. Geological Survey: U.S. Geological Survey Open-File Report 2002-0223, 7 p. (Also available at http:// pubs.usgs.gov/of/2002/ofr-02-0223/.)

Colorado Department of Public Health and Environment, 2003, Biosolids regulation: Colorado Department of Public Health and Environment, 5CCR 1002-64, variously paged [Revised on April 14, 2003 and subsequently]

Colorado Department of Public Health and Environment, 2004, The basic standards for groundwater: Colorado Department of Public Health and Environment, 5CCR 1002-41, variously paged [Revised on November 8, 2004 and subsequently]

Crock, J.G., Smith, D.B., Yager, T.J.B., Brown, Z.A., and Adams, M.G., 2008a, Analytical results for municipal biosolids samples from a monitoring program near Deer Trail, Colorado (USA), 1999 through 2006: U.S. Geological Survey Open-File Report 2008-1172, 67 p. (Also available at http://pubs.usgs.gov/of/2008/1172/.)

Crock, J.G., Smith, D.B., Yager, T.J.B., Berry, C.J., and Adams, M.G., 2008b, Analytical results for municipal biosolids samples from a monitoring program near Deer Trail, Colorado (U.S.A.), 2007: U.S. Geological Survey Open-File Report 2008-1358, 35 p. (Also available at http://pubs.usgs. gov/of/2008/1358/.)

Crock, J.G., Smith, D.B., Yager, T.J.B., Berry, C.J., and Adams, M.G., 2009a, Analytical results for municipal biosolids samples from a monitoring program near Deer Trail, Colorado (U.S.A.), 2008: U.S. Geological Survey Open-File Report 2009-1090, 25 p. (Also available at http://pubs.usgs. gov/of/2009/1090/.)

Crock, J.G., Smith, D.B., Yager, T.J.B., Berry, C.J., and Adams, M.G., 2010, Analytical results for municipal biosolids samples from a monitoring program near Deer Trail, Colorado (U.S.A.), 2009: U.S. Geological Survey Open-File Report 2010-1162, 23 p. (Also available at http://pubs.usgs. gov/of/2010/1162/.) 
Crock, J.G., Smith, D.B., and Yager, T.J.B., 2009b, Analytical results for agricultural soil samples from a monitoring program near Deer Trail, Colorado (U.S.A.): U.S. Geological Survey Open-File Report 2009-1111, 147 p. (Also available at http://pubs.usgs.gov/of/2010/1111/.)

Drew, L.J., Schuenemeyer, J.H., and Bawiec, W.J., 1979, Petroleum exhaustion maps of the Cretaceous "D-J" sandstone stratigraphic interval of the Denver Basin: U.S. Geological Survey Miscellaneous Investigations Series Map I-1138, scale 1:200,000, sheet 2.

Fishman, M.J., ed., 1993, Methods of analysis by the U.S. Geological Survey National Water Quality LaboratoryDetermination of inorganic and organic constituents in water and fluvial sediments: U.S. Geological Survey OpenFile Report 93-125, 217 p.

Fishman, M.J., and Friedman, L.C., 1989, Methods for determination of inorganic substances in water and fluvial sediments: U.S. Geological Survey Techniques of WaterResources Investigations, book 5, chap. A1, 545 p.

Friedman, L.C., and Erdmann, D.E., 1982, Quality-assurance practices for the chemical and biological analyses of water and fluvial sediments: U.S. Geological Survey Techniques of Water-Resources Investigations, book 5, chap. A6, 181 p.

Garbarino, J.R., and Damrau, D.L., 2001, Methods of analysis by the U.S. Geological Survey National Water Quality Laboratory-Determination of organic plus inorganic mercury in filtered and unfiltered natural water with cold vapor-automatic fluorescence spectrometry: U.S. Geological Survey Water-Resources Investigations Report 01-4132, 16 p.

Garbarino, J.R., Kanagy, L.K., and Cree, M.E., 2006, Determination of elements in natural-water, biota, sediment, and soil samples using collision/reaction cell inductively coupled plasma-mass spectrometry: U.S. Geological Survey Techniques and Methods, book 5, sec. B, chap. 1, 88 p.

Hageman, P.L., 2007, Determination of mercury in aqueous and geologic materials by continuous flow-cold vapor-atomic fluorescence spectrometry (CVAFS): U.S. Geological Survey Techniques and Methods, book 5, sec. D, chap. 2, 6 p. (Also available at http://pubs.usgs.gov/ $\mathrm{tm} / 2007 / 05 \mathrm{D} 02 /$.)

Horowitz, A.J., Demas, C.R., Fitzgerald, K.K., Miller, T.L., and Rickert, D.A., 1994, U.S. Geological Survey protocol for the collection and processing of surface-water samples for the subsequent determination of inorganic constituents in filtered water: U.S. Geological Survey Open-File Report 94-539, 57 p.

Larsen, L.S., Baber, T.G., Wesswick, E.L., McCoy, D.E., and Harman, J.B., 1966, Soil survey of Elbert County, Colorado: U.S. Department of Agriculture Soil Conservation Service Soil Survey Series 1960, No. 31, 79 p.
Larsen, L.S., and Brown, J.B., 1971, Soil survey of Arapahoe County, Colorado: U.S. Department of Agriculture Soil Conservation Service Soil Survey series, 78 p.

Lyon, W.S., 1980, Progress and problems in radioelement analysis: Ann Arbor, Mich., Ann Arbor Science, p. 215-221 and 223-230.

Major, T.J., Robson, S.G., Romero, J.C., and Zawistowski, Stanley, 1983, Hydrogeologic data from parts of the Denver Basin, Colorado: U.S. Geological Survey Open-File Report 83-274, $425 \mathrm{p}$.

Patton, C.J., and Truitt, E.P., 1992, Methods of analysis by the U.S. Geological Survey National Water Quality Laboratory-Determination of total phosphorus by a Kjeldahl digestion method and an automated colorimetric finish that includes dialysis: U.S. Geological Survey Open-File Report 92-146, 39 p. (Also available at http://nwql.usgs.gov/ Public/pubs/OFR92-146/OFR92-146.html.)

Patton, C.J., and Truitt, E.P., 2000, Methods of analysis by the U.S. Geological Survey National Water Quality Laboratory-Determination of ammonium plus organic nitrogen by a Kjeldahl digestion method and an automated photometric finish that includes digest cleanup by gas diffusion: U.S. Geological Survey Open-File Report 00-170, 31 p. (Also available at http://nwql.usgs.gov/Public/pubs/OFR00-170/ OFR00-170.html.)

Reheis, M.C., Honke, Jeff, Lamothe, Paul, and Fisher, Eric, 2009, Description and analytical results for deposited dust samples from a two-year monitoring program near Deer Trail, Colorado, USA, 2006-2007: U.S. Geological Survey Open-File Report 2008-1361, 12 p. (Also available at http://pubs.usgs.gov/of/2008/1361/.)

Robson, S.G., and Banta, E.R, 1995, Groundwater atlas of the United States, segment 2, Arizona, Colorado, New Mexico, Utah: U.S. Geological Survey Hydrologic Investigations Atlas 730-C, p. C20-C22. (Also available at http://pubs. usgs.gov/ha/ha730/ch_c/index.html.)

Robson, S.G., Wacinski, Andrew, Zawistowski, Stanley, and Romero, J.C., 1981, Geologic structure, hydrology, and water quality of the Laramie-Fox Hills aquifer in the Denver Basin, Colorado: U.S. Geological Survey Hydrologic Investigations Atlas Map HA-650, scale $1: 500,000$, sheet 1 .

Seaber, P.R., Kapinos, F.P., and Knapp, G.L., 1987, Hydrologic unit maps: U.S. Geological Survey Water-Supply Paper 2294, 63 p. (Also available at http://pubs.usgs.gov/ wsp/wsp2294/.)

Sharps, J.A., 1980, Geologic map of the Limon $1^{\circ} \mathrm{x} 2^{\circ}$ quadrangle, Colorado and Kansas: U.S. Geological Survey Miscellaneous Investigations Series Map I-1250, scale 1:250,000, sheet 1 . 
Stevens, M.R., Yager, T.J.B., Smith, D.B., and Crock, J.G., 2003, Biosolids, soils, ground-water, and streambedsediment data for a biosolids-application area near Deer Trail, Colorado: U.S. Geological Survey Open-File Report 02-51, 118 p. (Also available at http://pubs.usgs.gov/ of/2002/ofr02051/.)

Struzeski, T.M., DeGiacomo, W.J., and Zayhowski, E.J., 1996, Methods of analysis by the U.S. Geological Survey National Water Quality Laboratory-Determination of dissolved aluminum and boron in water by inductively coupled plasmaatomic emission spectrometry: U.S. Geological Survey Open-File Report 96-149, 17 p.

Taggart, J.E., Jr., ed., 2002, Analytical methods for chemical analysis of geologic and other materials, U.S. Geological Survey: U.S. Geological Survey Open-File Report 02-223, variously paginated. (Also available at http://pubs.usgs.gov/ of/2002/ofr-02-0223/.)

U.S. Geological Survey, 1974, Hydrologic unit map-1974, Colorado: U.S. Geological Survey Hydrologic Unit Map 1974, scale 1:500,000, 1 sheet.

U.S. Geological Survey, 1980, Land use and land cover, 1975, Limon, Colorado; Kansas: U.S. Geological Survey Land Use Series L-191, scale 1:250,000, 1 sheet.

U.S. Geological Survey, variously dated, National field manual for the collection of water-quality data: U.S. Geological Survey Techniques of Water-Resources Investigations, book 9, chaps. A1-A9. (Also available at http://pubs.water.usgs. gov/twri9A.).

Whittaker, E.L., and Grothaus, G.E., 1979, Acid dissolution method for the analysis of plutonium in soil: Las Vegas, Environmental Monitoring and Support Laboratory, Office of Research and Development, EPA-600/7-79-081, p. 23-59.

Yager, T.J.B., and Arnold, L.R., 2003, Hydrogeology of a biosolids-application site near Deer Trail, Colorado, 1993-99: U.S. Geological Survey Water-Resources Investigations Report 03-4209, 90 p. (Also available at http://pubs.usgs. gov/wri/wri034209.)

Yager, T.J.B., Smith, D.B., Crock, J.G., and Stevens, M.R., 2004a, Biosolids, soil, crop, ground-water, and streambedsediment data for a biosolids-application area near Deer Trail, Colorado, 2000: U.S. Geological Survey Open-File Report 03-400, 90 p. (Also available at http://pubs.usgs. gov/of/2003/ofro3-400.)

Yager, T.J.B., Smith, D.B., and Crock, J.G., 2004b, Biosolids, soil, crop, ground-water, and streambed-sediment data for a biosolids-application area near Deer Trail, Colorado, 2001: U.S. Geological Survey Open-File Report 2004-1388, 69 p. (Also available at http://pubs. usgs.gov/of/2004/1388.)
Yager, T.J.B., Smith, D.B., and Crock, J.G., 2004c, Biosolids, soil, crop, ground-water, and streambed-sediment data for a biosolids-application area near Deer Trail, Colorado, 2002-2003: U.S. Geological Survey Open-File Report 2004-1404, 90 p. (Also available at http://pubs.usgs.gov/ of/2004/1404.)

Yager, T.J.B., Smith, D.B., and Crock, J.G., 2004d, Effects of surface applications of biosolids on soil, crops, ground water, and streambed sediment near Deer Trail, Colorado, 1999-2003: U.S. Geological Survey Scientific Investigations Report 2004-5289, 93 p. (Also available at $h t t p: / /$ pubs.usgs.gov/sir/2004/5289.)

Yager, T.J.B., Smith, D.B., and Crock, J.G., 2009, Biosolids, crop, and ground-water data for a biosolids-application area near Deer Trail, Colorado, 2004-2006: Denver, U.S. Geological Survey Data Series 379, 57 p. (Also available at http://pubs.usgs.gov/ds/379.)

Publishing support provided by:

Denver Publishing Service Center

For more information concerning this publication, contact: Director, USGS Colorado Water Science Center Box 25046, Mail Stop 415

Denver, CO 80225

(303) 236-4882

Or visit the Colorado Water Science Center Web site at: http://co.water.usgs.gov/ 
Data Section 


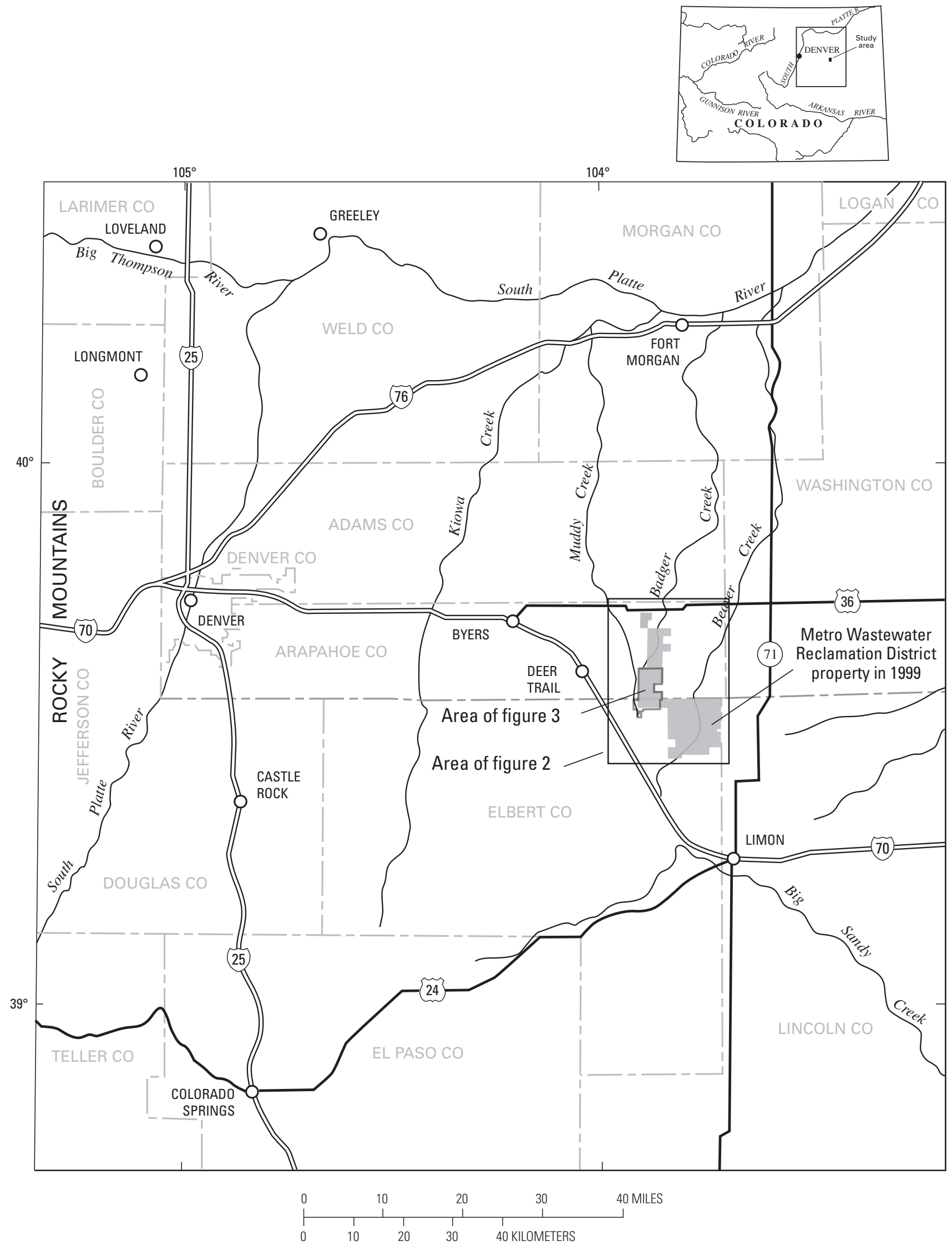

Figure 1. Location of study area near Deer Trail, Colorado. 


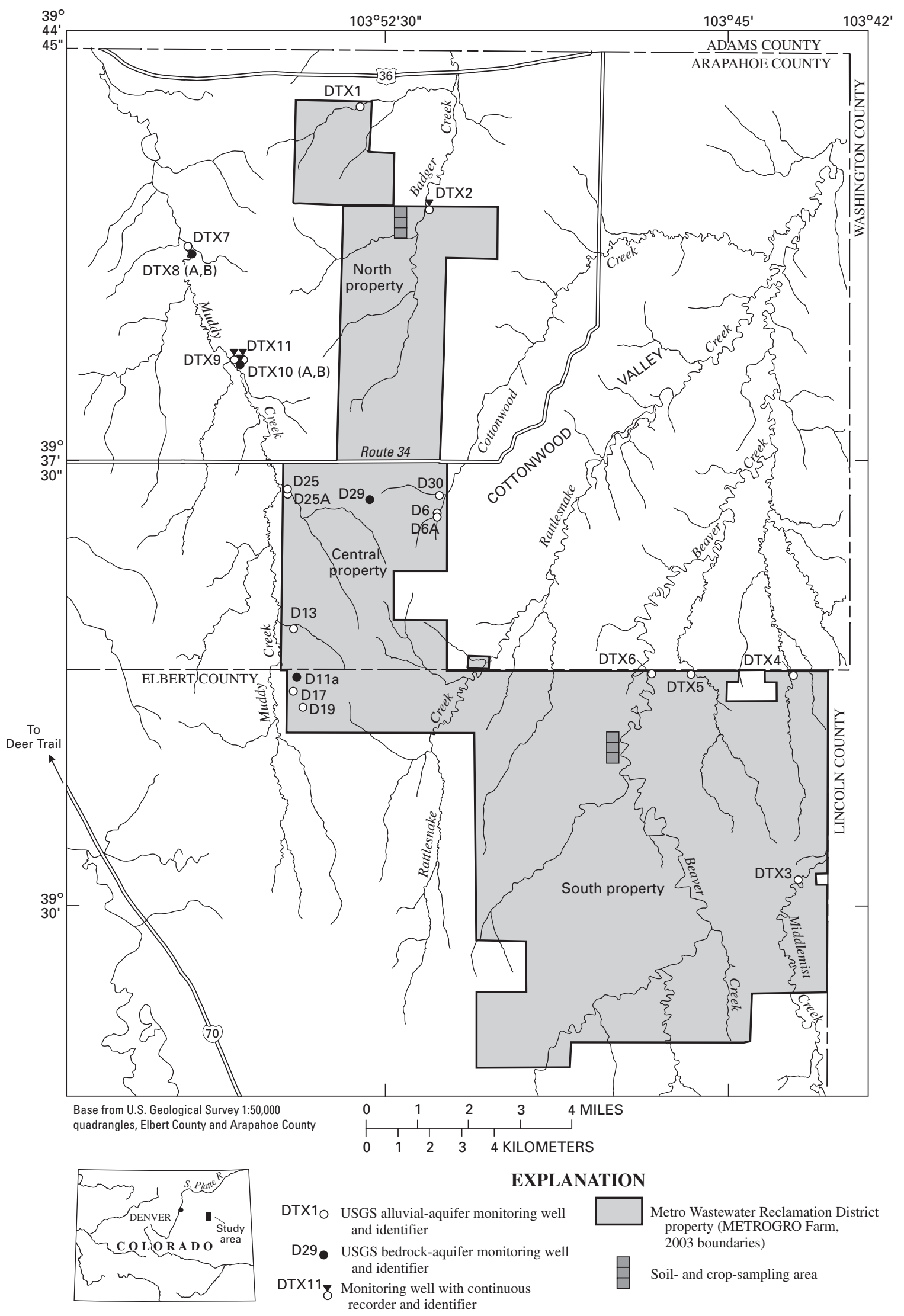

Figure 2. Location of U.S. Geological Survey Expanded Monitoring Program sites near Deer Trail, Colorado, 2007 and 2008. 


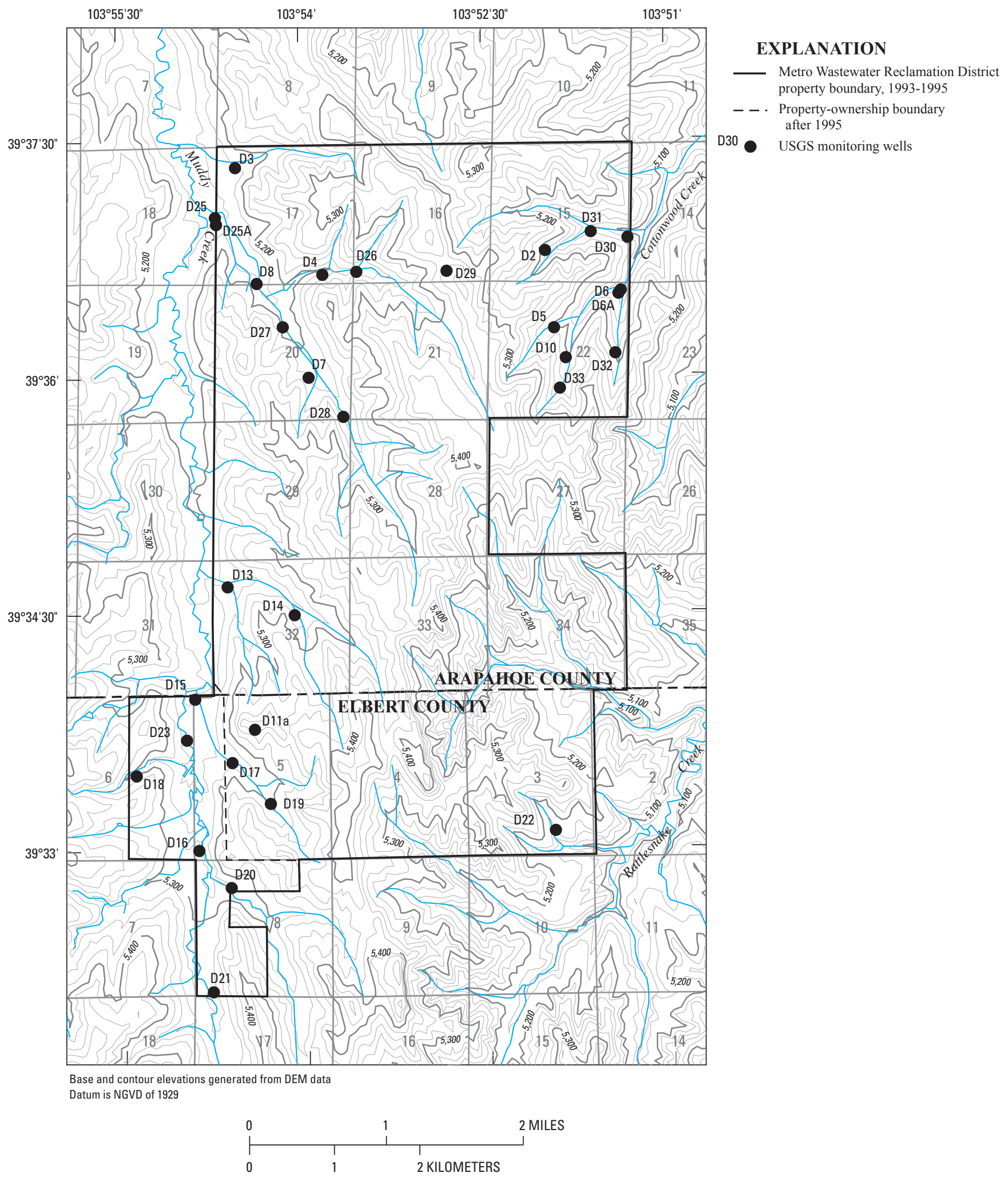

Figure 3. Locations of U.S. Geological Survey monitoring wells during 2007 and 2008 on the original (1993-1995) Metro Wastewater Reclamation District property near Deer Trail, Colorado, now part of the METROGRO Farm central property. 


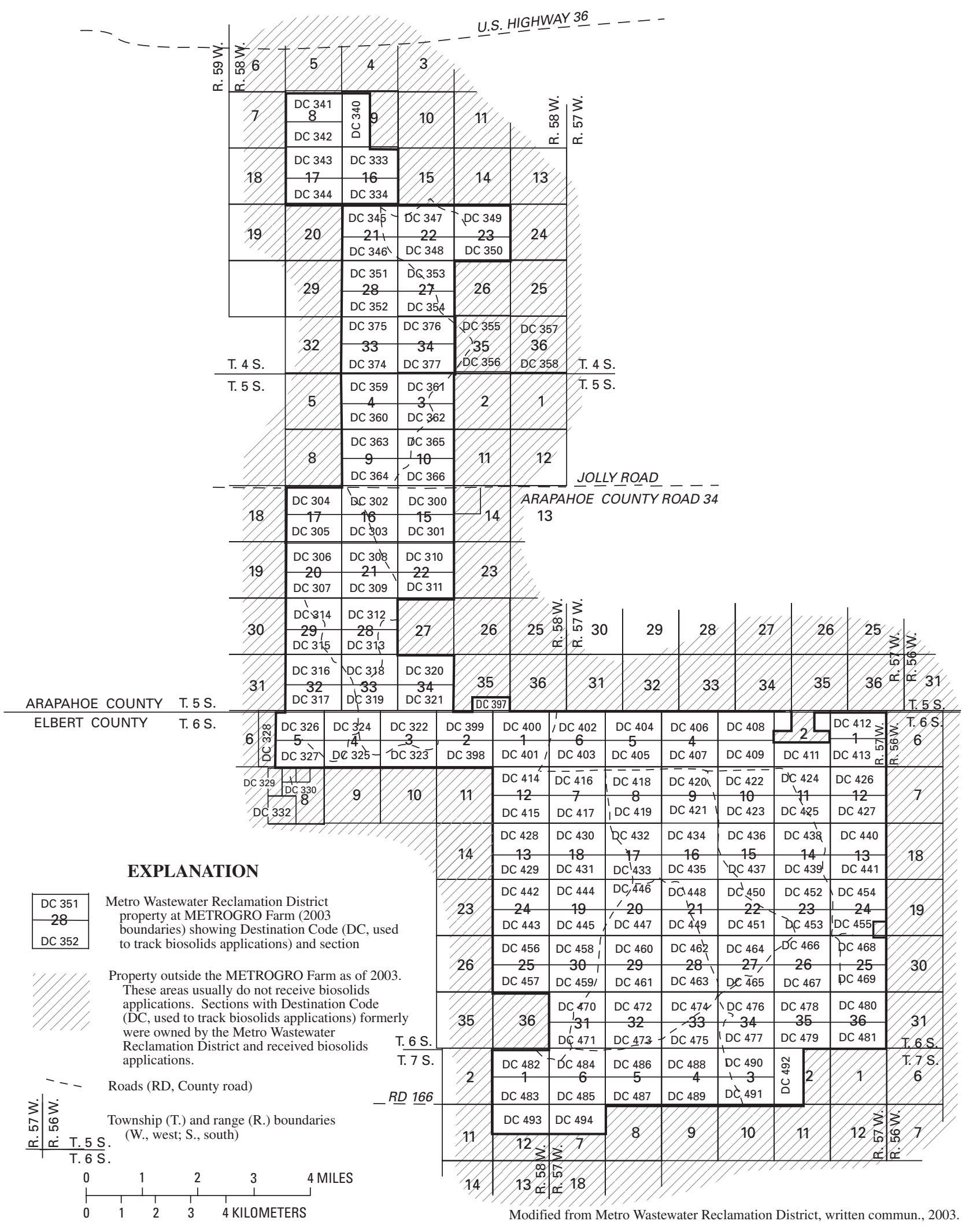

Figure 4. Metro Wastewater Reclamation District biosolids-application areas near Deer Trail, Colorado, 2007 and 2008. 


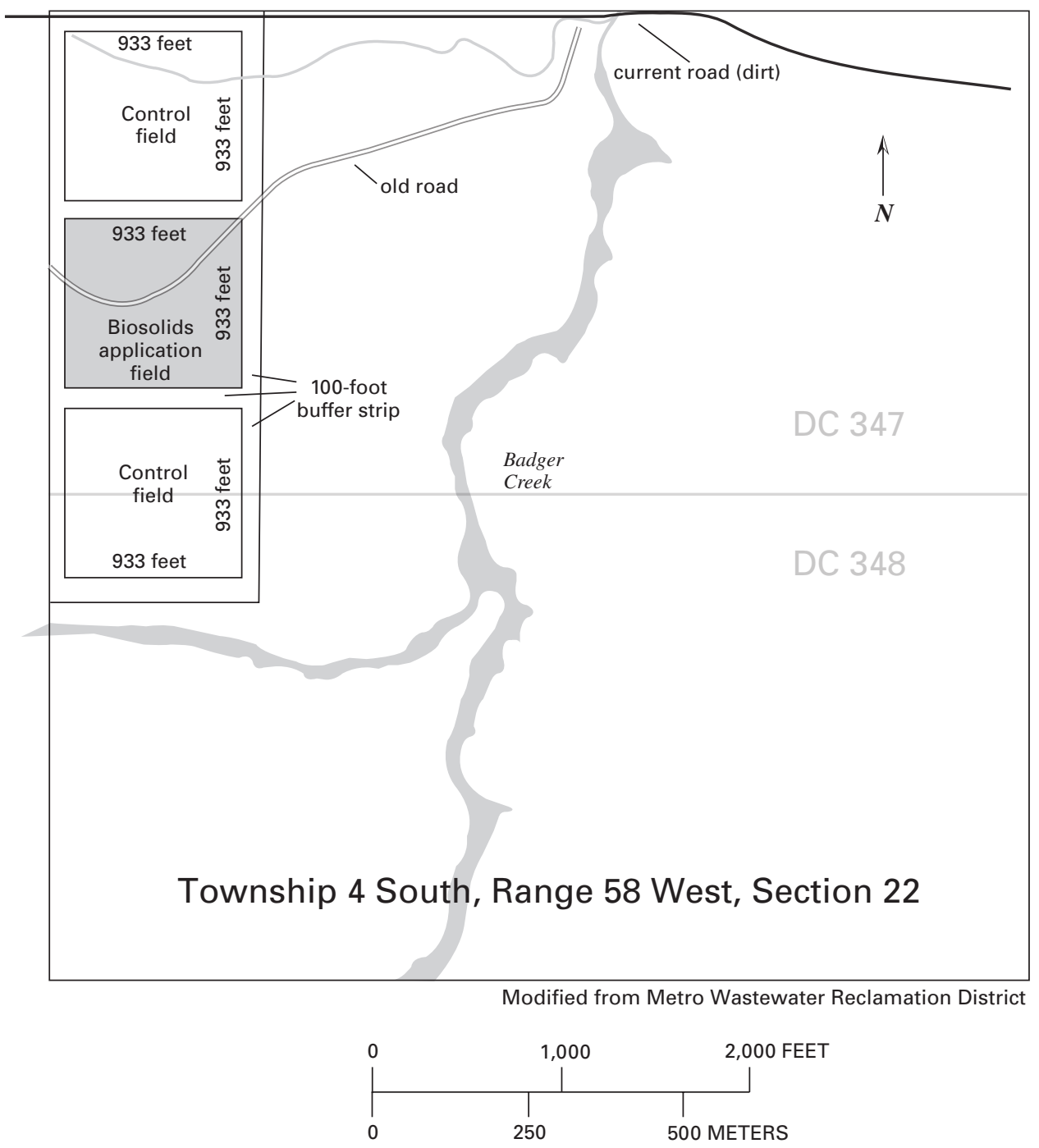

Figure 5. Arapahoe County, Colorado, soil- and crop-sampling area. 


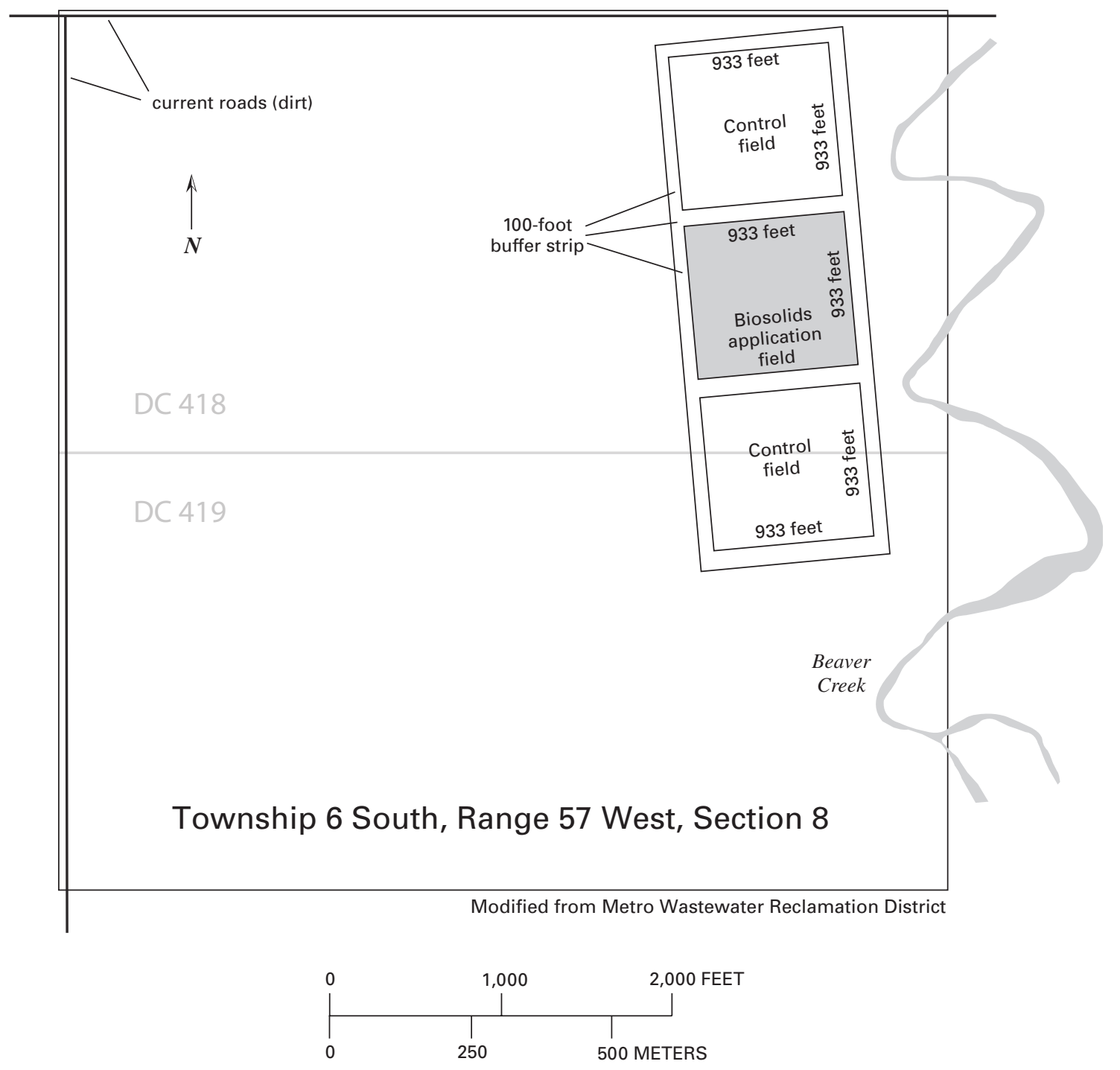

Figure 6. Elbert County, Colorado, soil- and crop-sampling area. 

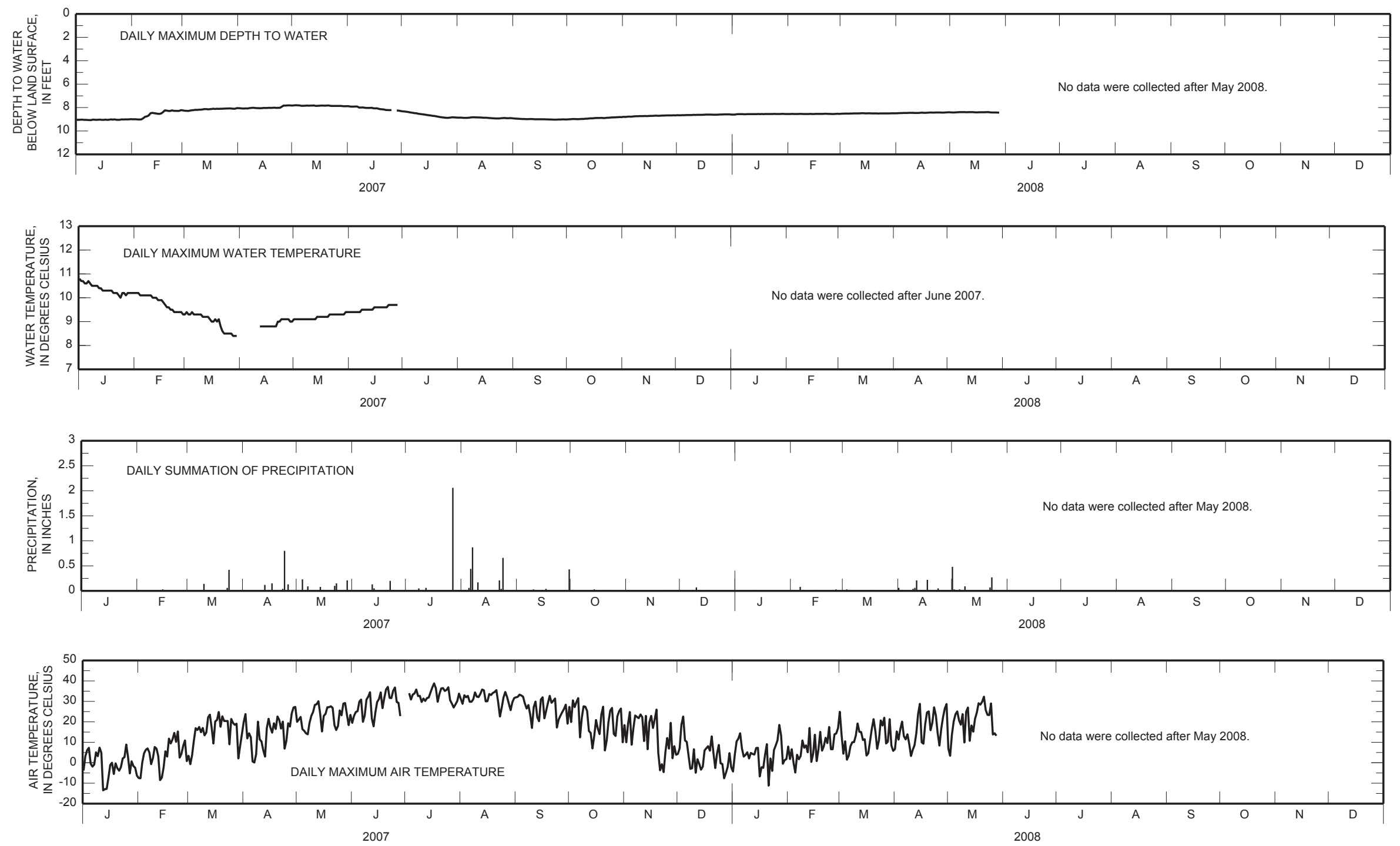

Figure 7. Continuous depth-to-water, water-temperature, precipitation, and air-temperature data for well DTX2 near Deer Trail, Colorado, 2007 and 2008. 

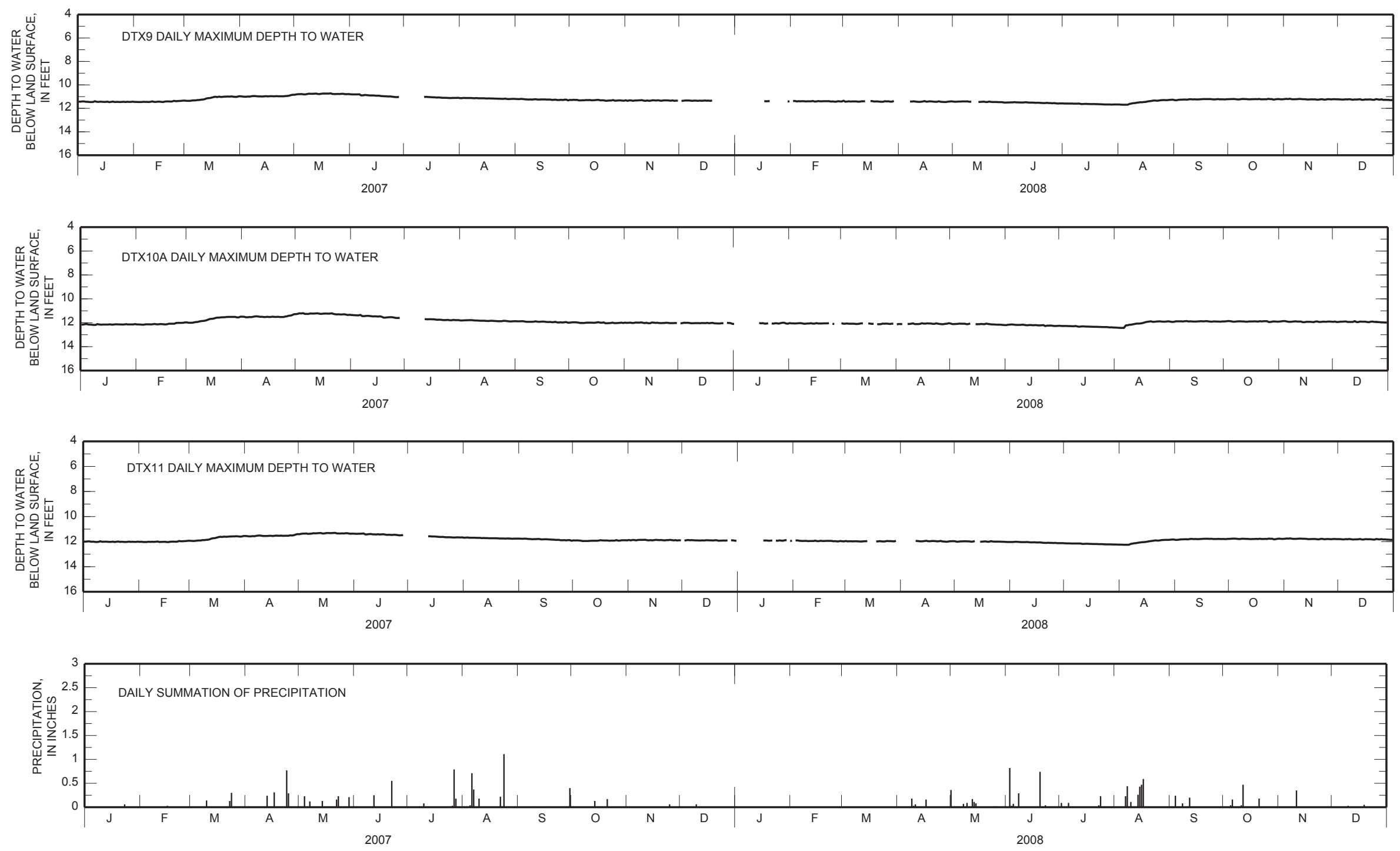

Figure 8. Continuous depth-to-water and precipitation data for wells DTX9, DTX10, and DTX11 (a recharge-evaluation site) near Deer Trail, Colorado, 2007 and 2008. 


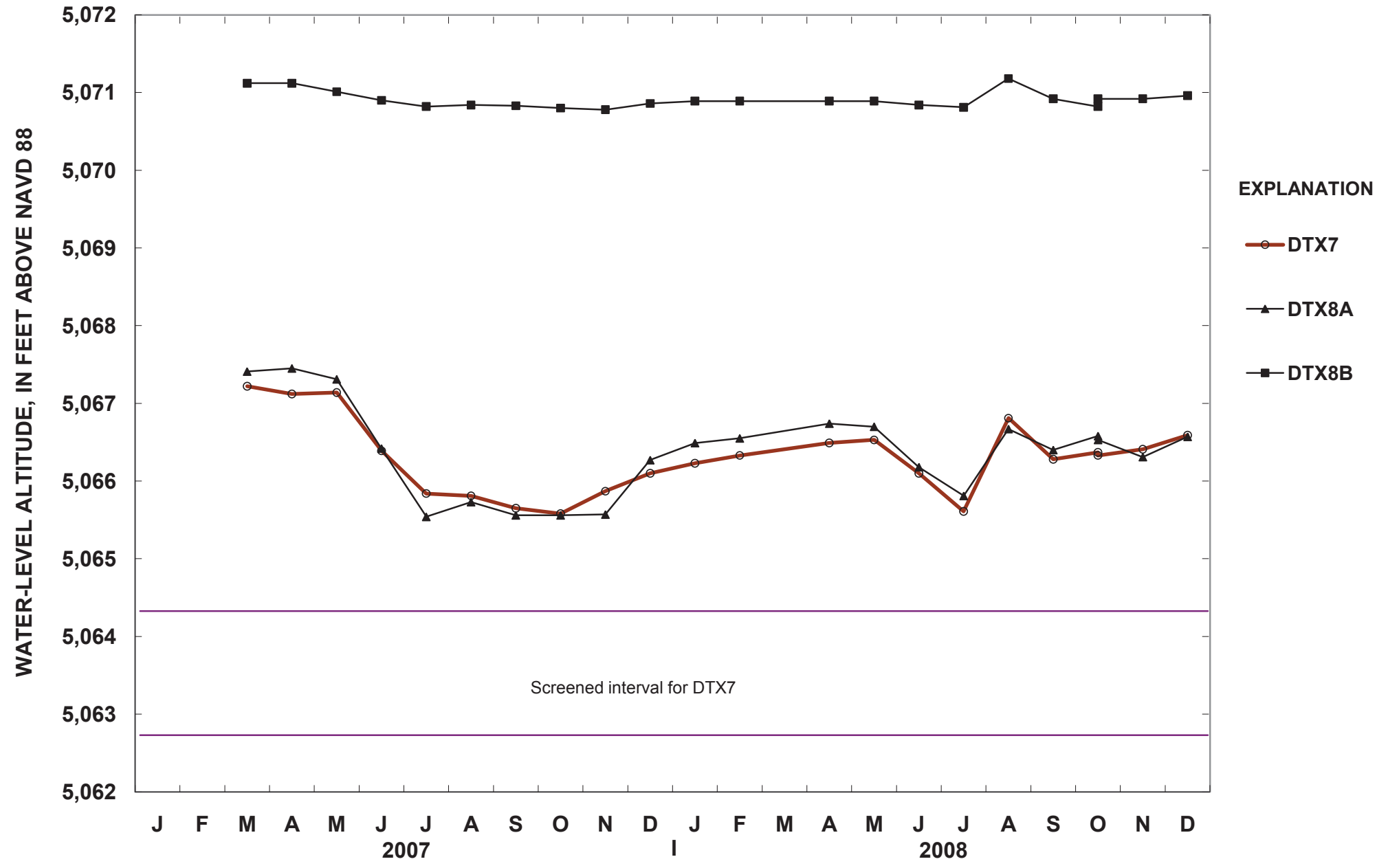

Figure 9. Water-level comparison for the recharge-evaluation site containing wells DTX7, DTX8 near Deer Trail, Colorado, 2007 and 2008. 


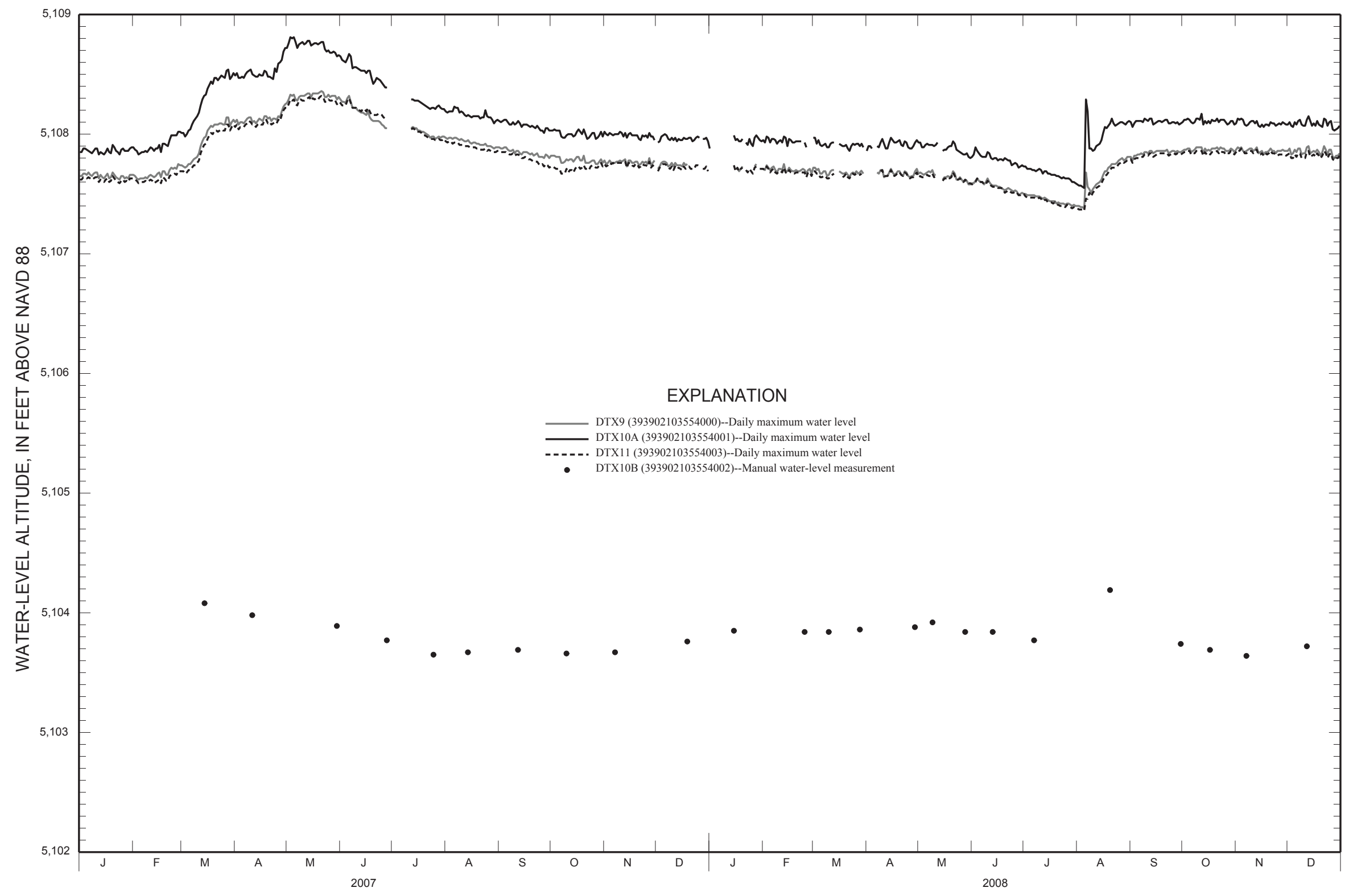

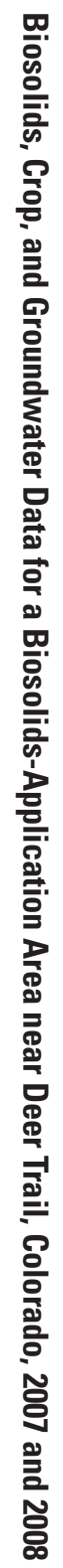

Figure 10. Water-level comparison for the recharge-evaluation site containing wells DTX9, DTX10, and DTX11 near Deer Trail, Colorado, 2007 and 2008. 

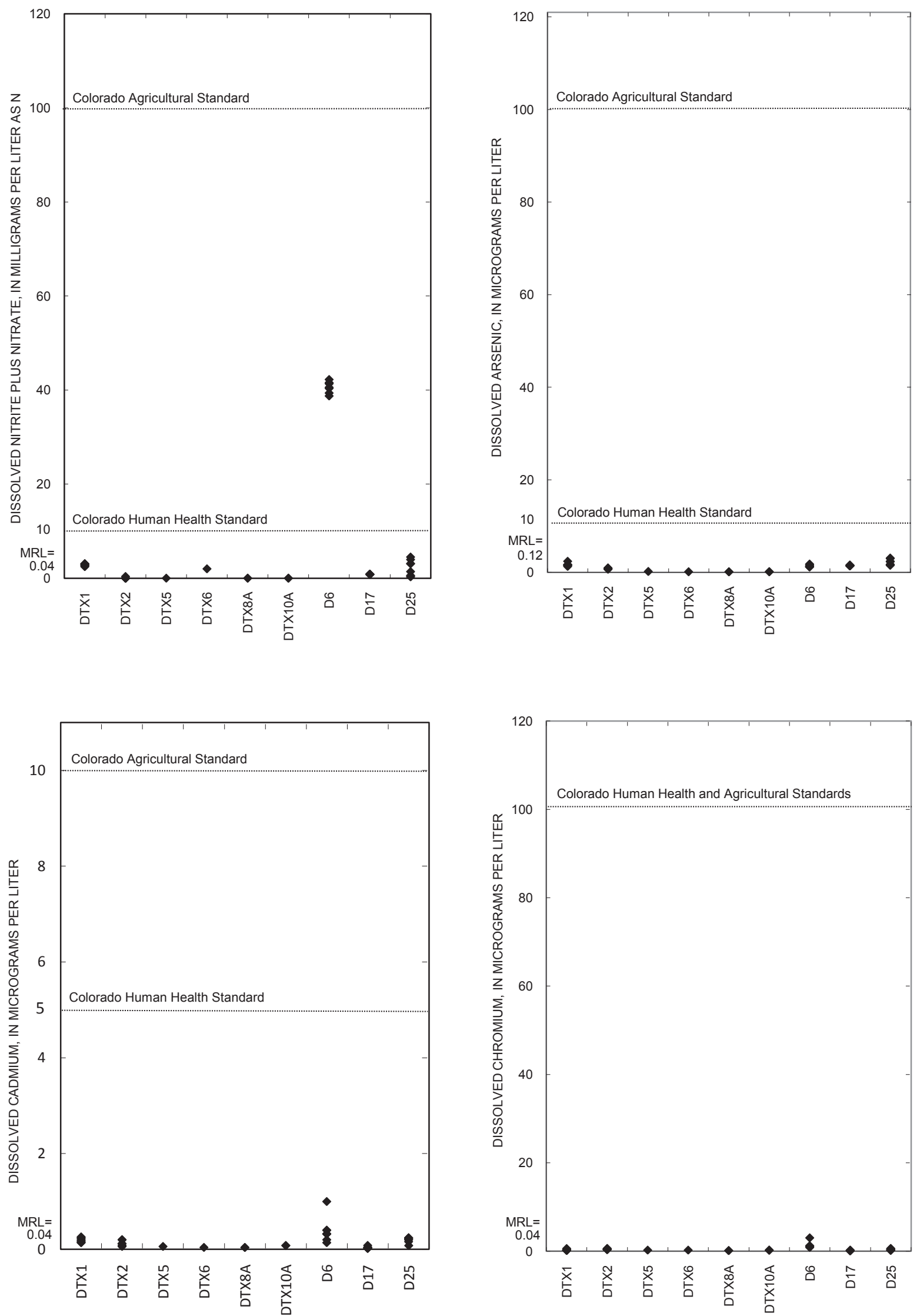

Figure 11. Distribution of groundwater constituent data collected near Deer Trail, Colorado, compared to regulatory standards for selected constituents, 2007 and 2008. 

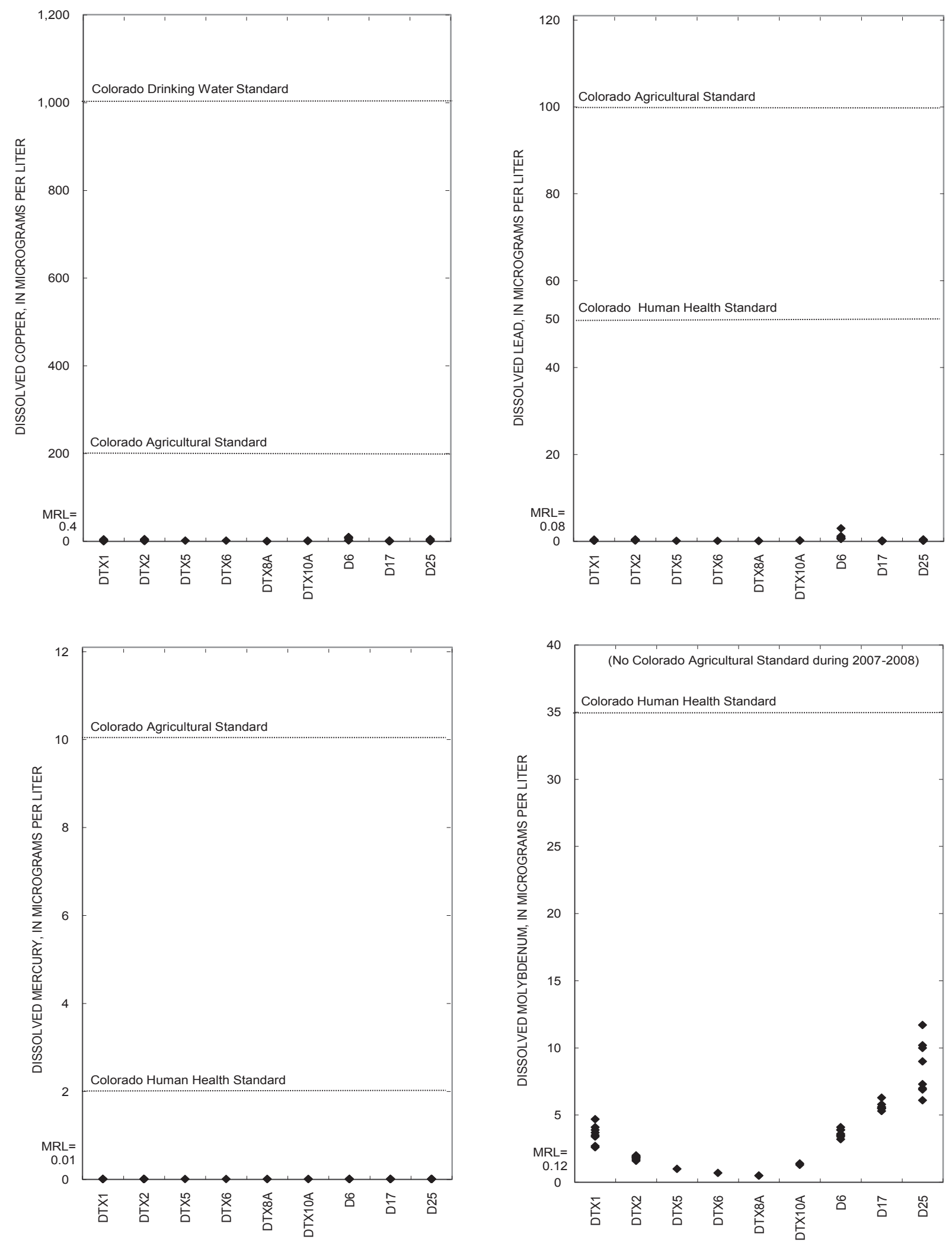

Figure 11. Distribution of groundwater constituent data collected near Deer Trail, Colorado, compared to regulatory standards for selected constituents, 2007 and 2008.-Continued 

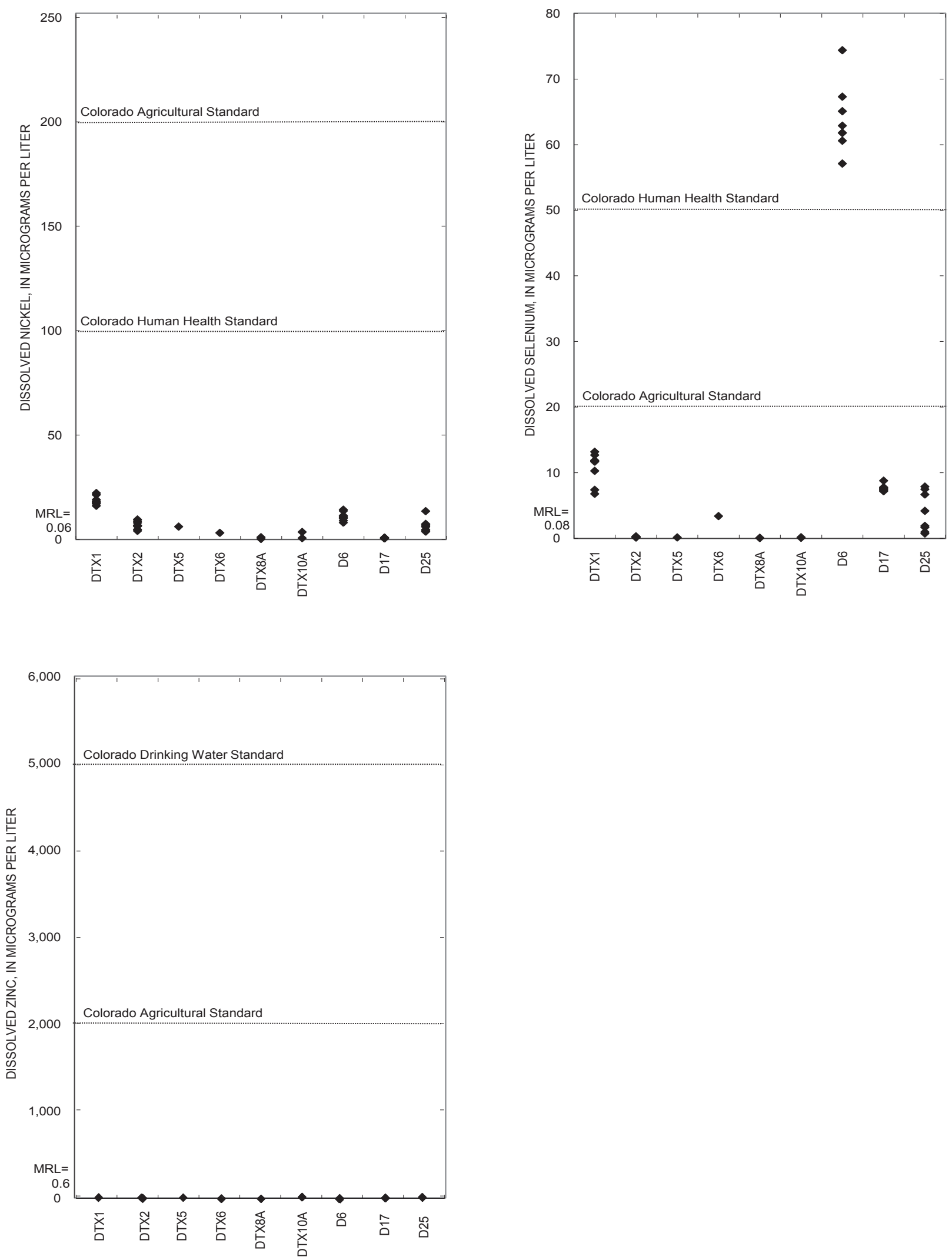

Figure 11. Distribution of groundwater constituent data collected near Deer Trail, Colorado, compared to regulatory standards for selected constituents, 2007 and 2008.-Continued 

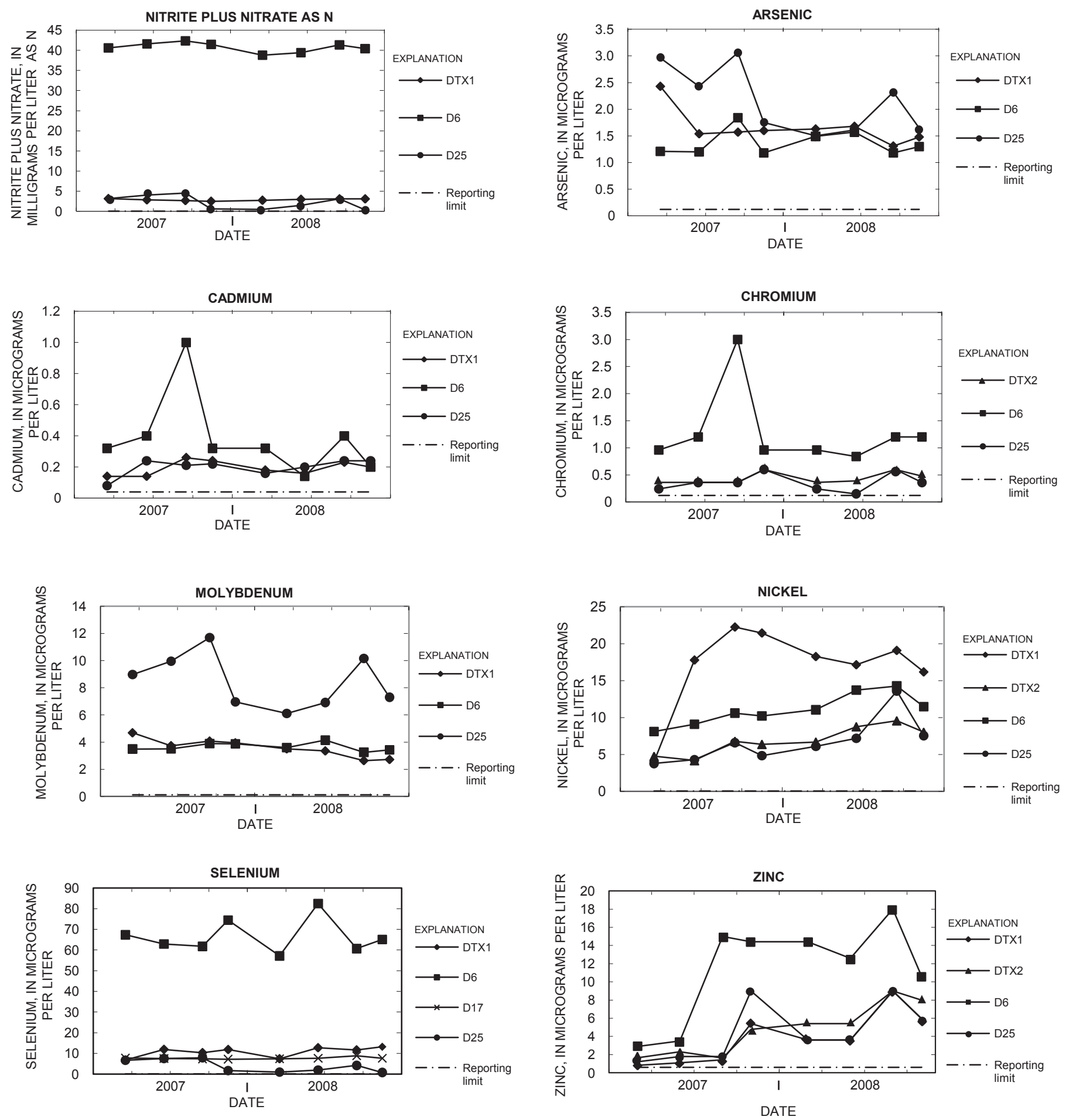

Figure 12. Groundwater concentrations near Deer Trail, Colorado, for selected constituents, 2007 and 2008. (N, nitrogen) 
Table 1. Biosolids applications by Metro Wastewater Reclamation District to the study area near Deer Trail, Colorado, 2007 and 2008.

[All information provided by the Metro Wastewater Reclamation District; DC, destination code; Ac, acre; wT, wet tons; dT, dry tons; CAKE, Table 3 Class B biosolids; Rec, recommended; N, nitrogen; lbs, pounds; \%, percent; P, phosphorous; K, potassium; TKN, Total Kjeldahl Nitrogen; PAN, plant available nitrogen; incorporated, biosolids are pushed down into the soil 4 to 8 inches after application by the tines of a rotating implement pulled by a tractor; surface, no incorporation step]

\begin{tabular}{|c|c|c|c|c|c|c|c|c|c|c|c|c|c|c|c|c|c|c|c|c|c|}
\hline $\begin{array}{r}D C \\
\text { (fig. 4) }\end{array}$ & $\begin{array}{l}\text { Total DC } \\
\text { area, AC }\end{array}$ & $\begin{array}{l}\text { Application } \\
\text { start date }\end{array}$ & $\begin{array}{l}\text { Application } \\
\text { stop date }\end{array}$ & $\begin{array}{c}\text { Area } \\
\text { applied, } \\
\text { Ac }\end{array}$ & $\begin{array}{c}\text { Product } \\
\text { applied }\end{array}$ & $\begin{array}{c}\text { Application } \\
\text { method }\end{array}$ & $\begin{array}{c}\text { Total wT } \\
\text { applied }\end{array}$ & $\begin{array}{c}\text { Actual } \\
\text { loading } \\
\text { rate, } \\
\text { wT/Ac }\end{array}$ & $\begin{array}{l}\text { Total dT } \\
\text { applied }\end{array}$ & $\begin{array}{c}\text { Actual } \\
\text { loading } \\
\text { rate, dT } \\
\text { Cake/ Ac }\end{array}$ & $\begin{array}{c}\text { Rec N } \\
\text { loading } \\
\text { rate, } \\
\text { Ibs/Ac }\end{array}$ & $\begin{array}{c}\text { Rec } \mathrm{N}- \\
\text { based } \\
\text { loading } \\
\text { rate, } \\
\text { dT/Ac }\end{array}$ & $\begin{array}{l}\% \text { of Rec } \\
\mathrm{N} \text { applied }\end{array}$ & $\begin{array}{c}\text { Actual N } \\
\text { loading } \\
\text { rate, } \\
\text { Ibs/Ac }\end{array}$ & $\begin{array}{l}\text { Total P } \\
\text { applied, } \\
\text { Ibs/Ac }\end{array}$ & $\begin{array}{l}\text { Total K } \\
\text { applied, } \\
\text { Ibs/Ac }\end{array}$ & Crop & $\begin{array}{c}\text { Reclamation } \\
\text { project? }\end{array}$ & $\begin{array}{l}\text { Total Rec } \\
\text { N/Crop, } \\
\text { Ibs/field }\end{array}$ & $\begin{array}{c}\text { TKN } \\
\text { fraction of } \\
\text { CAKE }\end{array}$ & $\begin{array}{l}\text { PAN, } \\
\text { Ibs/dT }\end{array}$ \\
\hline 300 & 320 & 07/10/08 & $07 / 11 / 08$ & 153.90 & Cake & Incorporated & 630.83 & 4.10 & 144.82 & 0.94 & 40 & 1.12 & 80 & 32.18 & 41.59 & 2.41 & Wheat & No & 6,156 & 0.0626 & 34.20 \\
\hline 301 & 320 & $07 / 11 / 08$ & 07/14/08 & 159.90 & Cake & Incorporated & 653.66 & 4.09 & 150.34 & 0.94 & 40 & 1.12 & 80 & 32.16 & 41.56 & 2.41 & Wheat & No & 6,396 & 0.0626 & 34.20 \\
\hline 333 & 320 & 06/25/08 & 06/28/08 & 314.05 & Cake & Incorporated & $1,273.78$ & 4.06 & 289.91 & 0.92 & 40 & 1.16 & 82 & 32.86 & 42.09 & 2.58 & Wheat & No & 12,562 & 0.0658 & 35.60 \\
\hline 334 & 320 & $06 / 21 / 08$ & $06 / 25 / 08$ & 283.76 & Cake & Incorporated & $1,139.32$ & 4.02 & 250.66 & 0.88 & 40 & 1.16 & 79 & 31.45 & 40.28 & 2.47 & Wheat & No & 11,350 & 0.0658 & 35.60 \\
\hline 340 & 320 & $06 / 13 / 07$ & 07/09/07 & 267.21 & Cake & Surface & $1,052.16$ & 3.94 & 249.07 & 0.93 & 40 & 1.22 & 87 & 34.67 & 43.44 & 2.87 & Wheat & No & 10,688 & 0.0654 & 37.20 \\
\hline 341 & 320 & $05 / 25 / 07$ & 05/29/07 & 220.95 & Cake & Surface & 878.55 & 3.98 & 217.30 & 0.98 & 40 & 1.10 & 81 & 32.26 & 46.22 & 3.03 & Wheat & No & 8,838 & 0.0614 & 32.80 \\
\hline 341 & 320 & 07/07/08 & 07/07/08 & 60.99 & Cake & Incorporated & 240.44 & 3.94 & 54.10 & 0.89 & 40 & 1.12 & 76 & 30.34 & 39.21 & 2.27 & Wheat & No & 2,440 & 0.0626 & 34.20 \\
\hline 342 & 320 & $05 / 25 / 07$ & $05 / 2 / 507$ & 48.16 & Cake & Surface & 176.39 & 3.66 & 43.74 & 0.91 & 40 & 1.10 & 75 & 29.84 & 42.69 & 2.80 & Wheat & No & 1,926 & 0.0615 & 32.85 \\
\hline 342 & 320 & 07/07/08 & 07/10/08 & 243.46 & Cake & Incorporated & $1,002.25$ & 4.12 & 220.88 & 0.91 & 40 & 1.12 & 78 & 31.03 & 40.10 & 2.32 & Wheat & No & 9,738 & 0.0626 & 34.20 \\
\hline 344 & 279 & $11 / 30 / 07$ & $12 / 04 / 07$ & 273.03 & Cake & Incorporated & $1,074.81$ & 3.94 & 217.96 & 0.80 & 40 & 1.12 & 75 & 30.02 & 40.87 & 2.59 & Wheat & No & 10,921 & 0.0690 & 37.60 \\
\hline 359 & 320 & 06/05/08 & $06 / 10 / 08$ & 259.96 & Cake & Incorporated & $1,063.55$ & 4.09 & 229.49 & 0.88 & 40 & 1.16 & 79 & 31.43 & 40.26 & 2.47 & Wheat & No & 10,398 & 0.0658 & 35.60 \\
\hline 360 & 320 & $06 / 10 / 08$ & $06 / 11 / 08$ & 83.36 & Cake & Incorporated & 319.73 & 3.84 & 72.27 & 0.87 & 40 & 1.16 & 77 & 30.86 & 39.53 & 2.43 & Wheat & No & 3,334 & 0.0658 & 35.60 \\
\hline 361 & 320 & 06/11/08 & 06/17/08 & 208.90 & Cake & Incorporated & 841.32 & 4.03 & 189.31 & 0.91 & 40 & 1.16 & 81 & 32.26 & 41.32 & 2.54 & Wheat & No & 8,356 & 0.0658 & 35.60 \\
\hline 362 & 320 & $06 / 11 / 08$ & $06 / 13 / 08$ & 171.16 & Cake & Incorporated & 696.20 & 4.07 & 144.64 & 0.85 & 40 & 1.16 & 75 & 30.08 & 38.53 & 2.37 & Wheat & No & 6,846 & 0.0658 & 35.60 \\
\hline 363 & 320 & $06 / 13 / 08$ & $06 / 13 / 08$ & 80.83 & Cake & Incorporated & 323.32 & 4.00 & 60.14 & 0.74 & 40 & 1.16 & 66 & 26.49 & 33.93 & 2.08 & Wheat & No & 3,233 & 0.0658 & 35.60 \\
\hline 364 & 320 & $06 / 18 / 08$ & $06 / 20 / 08$ & 139.76 & Cake & Incorporated & 569.46 & 4.07 & 131.07 & 0.94 & 40 & 1.16 & 83 & 33.39 & 42.76 & 2.63 & Wheat & No & 5,590 & 0.0658 & 35.60 \\
\hline 365 & 320 & $06 / 13 / 08$ & $06 / 18 / 08$ & 149.74 & Cake & Incorporated & 614.25 & 4.10 & 137.25 & 0.92 & 40 & 1.16 & 82 & 32.63 & 41.80 & 2.57 & Wheat & No & 5,990 & 0.0658 & 35.60 \\
\hline 366 & 320 & $06 / 20 / 08$ & $06 / 23 / 08$ & 140.12 & Cake & Incorporated & 566.82 & 4.05 & 133.53 & 0.95 & 40 & 1.16 & 85 & 33.93 & 43.46 & 2.67 & Wheat & No & 5,605 & 0.0658 & 35.60 \\
\hline 440 & 320 & $11 / 06 / 07$ & $11 / 08 / 07$ & 204.85 & Cake & Incorporated & 842.64 & 4.11 & 164.40 & 0.80 & 40 & 1.12 & 71 & 28.57 & 43.18 & 2.74 & Wheat & No & 8,194 & 0.0656 & 35.60 \\
\hline 441 & 320 & $10 / 31 / 07$ & $11 / 06 / 07$ & 291.10 & Cake & Incorporated & $1,212.93$ & 4.17 & 259.55 & 0.89 & 40 & 1.12 & 80 & 31.92 & 43.51 & 2.78 & Wheat & No & 11,644 & 0.0652 & 35.80 \\
\hline 454 & 320 & $10 / 27 / 07$ & $10 / 31 / 07$ & 290.92 & Cake & Incorporated & $1,107.54$ & 3.81 & 229.46 & 0.79 & 40 & 1.16 & 71 & 28.24 & 36.60 & 2.35 & Wheat & No & 11,637 & 0.0647 & 35.80 \\
\hline 468 & 320 & $10 / 24 / 07$ & $10 / 27 / 07$ & 232.89 & Cake & Incorporated & 975.25 & 4.19 & 213.44 & 0.92 & 40 & 1.16 & 82 & 32.81 & 42.52 & 2.73 & Wheat & No & 9,316 & 0.0647 & 35.80 \\
\hline 469 & 320 & $10 / 16 / 07$ & $10 / 24 / 07$ & 284.66 & Cake & Incorporated & $1,163.60$ & 4.09 & 236.35 & 0.83 & 40 & 1.16 & 74 & 29.72 & 38.53 & 2.47 & Wheat & No & 11,386 & 0.0647 & 35.80 \\
\hline 480 & 320 & $10 / 11 / 07$ & $10 / 16 / 07$ & 275.19 & Cake & Incorporated & $1,336.67$ & 4.86 & 243.80 & 0.89 & 50 & 1.45 & 63 & 31.72 & 41.11 & 2.64 & Corn & No & 13,760 & 0.0647 & 35.80 \\
\hline 481 & 320 & $10 / 05 / 07$ & $10 / 10 / 07$ & 254.87 & Cake & Incorporated & $1,323.54$ & 5.19 & 279.08 & 1.09 & 50 & 1.45 & 78 & 39.20 & 50.81 & 3.26 & Corn & No & 12,744 & 0.0647 & 35.80 \\
\hline
\end{tabular}


Table 2. Methods used to analyze biosolids samples collected at the Metro Wastewater Reclamation District and crop samples collected near Deer Trail, Colorado, 2007 and 2008.

[HG, hydride generation; AAS, atomic absorption spectrophotometry; ICP, inductively coupled plasma; MS, mass spectrometry; AES, atomic emission spectrometry; CV-AFS, continuous flow-cold vapor-atomic fluorescence spectrometry; IR, infrared]

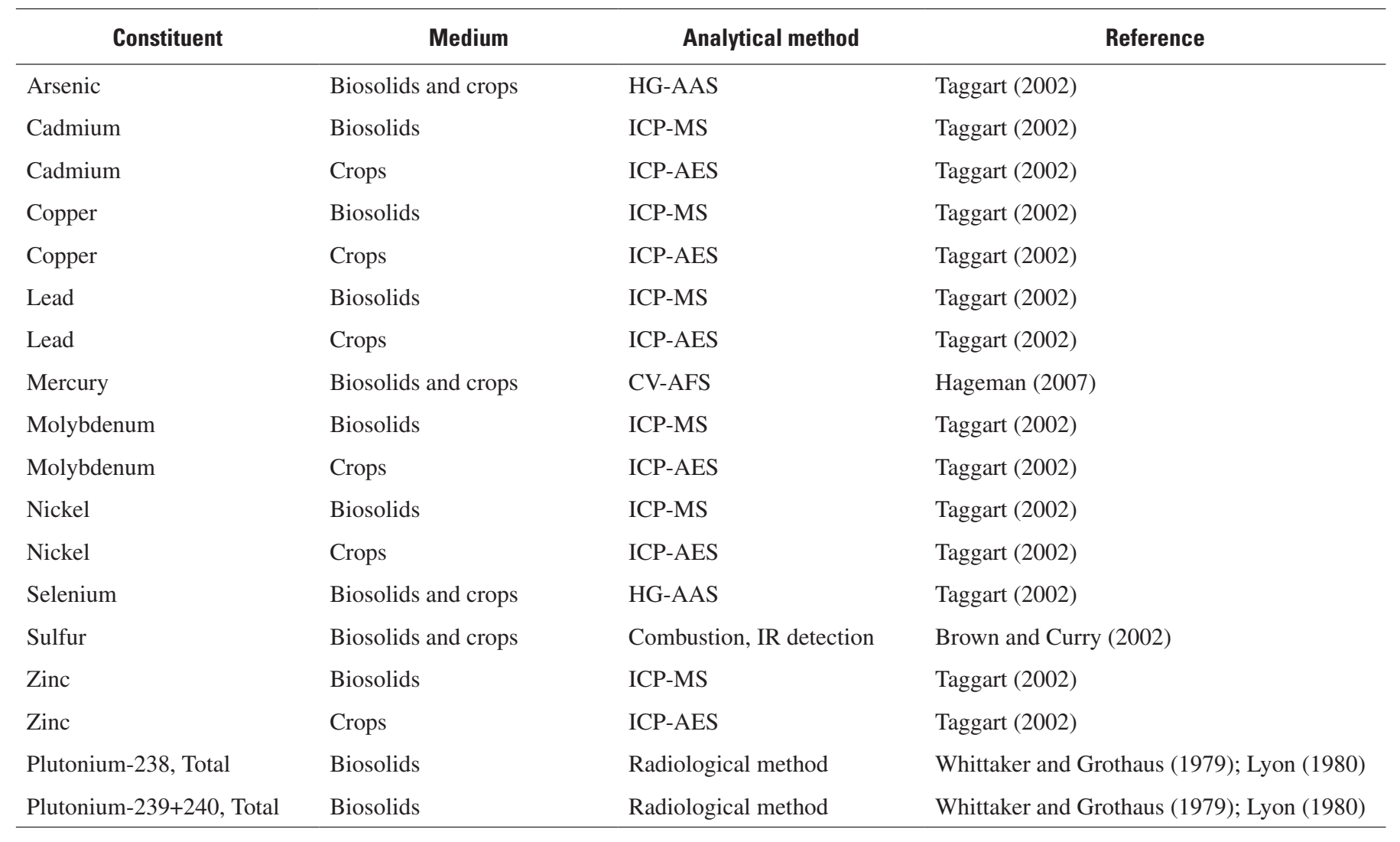


Table 3. Chemical data for biosolids samples collected at the Metro Wastewater Reclamation District, 2007 and 2008.

["Table 1 Ceiling Concentration Limits" and "Table 3 Pollutant Concentration Limits" from Colorado Department of Public Health and Environment (2003); ppm, parts per million; $\%$, percent]

\begin{tabular}{|c|c|c|c|c|c|c|c|c|c|c|}
\hline $\begin{array}{c}\text { Sample } \\
\text { date }\end{array}$ & $\begin{array}{c}\text { Arsenic, } \\
\text { ppm }\end{array}$ & $\begin{array}{c}\text { Cadmium, } \\
\text { ppm }\end{array}$ & $\begin{array}{c}\text { Copper, } \\
\text { ppm }\end{array}$ & $\begin{array}{l}\text { Lead, } \\
\text { ppm }\end{array}$ & $\begin{array}{l}\text { Mercury, } \\
\text { ppm }\end{array}$ & $\begin{array}{l}\text { Molybdenum, } \\
\text { ppm }\end{array}$ & $\begin{array}{c}\text { Nickel, } \\
\text { ppm }\end{array}$ & $\begin{array}{l}\text { Selenium, } \\
\text { ppm }\end{array}$ & $\begin{array}{c}\text { Sulfur, } \\
\%\end{array}$ & $\begin{array}{c}\text { Zinc, } \\
\text { ppm }\end{array}$ \\
\hline January 2007 & 0.3 & 1.9 & 714 & 44 & 0.61 & 22.4 & 20 & 11 & 1.57 & 787 \\
\hline February 2007 & 0.6 & 2.1 & 634 & 43 & 0.63 & 20.9 & 20 & 9.1 & 1.56 & 705 \\
\hline March 2007 & 0.7 & 2.3 & 600 & 43 & 0.83 & 19.8 & 19 & 9.8 & 1.59 & 683 \\
\hline April 2007 & 0.5 & 2.6 & 748 & 54 & 0.76 & 24.7 & 23 & 12 & 1.64 & 822 \\
\hline May 2007 & 1.1 & 2.5 & 824 & 55 & 1.42 & 25.3 & 26 & 13 & 1.62 & 935 \\
\hline June 2007 & 1.2 & 2.4 & 801 & 68 & 0.73 & 23.8 & 24 & 17 & 1.64 & 899 \\
\hline July 2007 & 1.3 & 2.9 & 952 & 68 & 1.03 & 34.0 & 28 & 11 & 1.88 & 1,160 \\
\hline August 2007 & 1.4 & 2.6 & 851 & 61 & 1.04 & 34.2 & 26 & 14 & 1.62 & 1,060 \\
\hline September 2007 & 1.0 & 2.4 & 820 & 59 & 1.26 & 32.5 & 24 & 14 & 1.72 & 986 \\
\hline October 2007 & 0.8 & 2.3 & 816 & 58 & 2.38 & 26.5 & 26 & 16 & 1.67 & 962 \\
\hline November 2007 & 0.4 & 1.9 & 698 & 56 & 0.92 & 22.2 & 22 & 12 & 1.60 & 811 \\
\hline December 2007 & 0.5 & 2.2 & 754 & 56 & 0.85 & 22.2 & 21 & 12 & 1.59 & 868 \\
\hline January 2008 & 2.8 & 2.0 & 706 & 38 & 0.96 & 19.8 & 18 & 12 & 1.61 & 745 \\
\hline February 2008 & 1.4 & 2.1 & 755 & 37 & 1.18 & 20.8 & 19 & 11 & 1.60 & 768 \\
\hline March 2008 & 1.2 & 1.9 & 706 & 36 & 0.97 & 18.0 & 17 & 8.6 & 1.53 & 754 \\
\hline April 2008 & 2.6 & 1.8 & 666 & 41 & 1.02 & 19.3 & 18 & 8.8 & 1.57 & 714 \\
\hline May 2008 & 4.0 & 2.2 & 767 & 45 & 1.18 & 18.8 & 19 & 10 & 1.59 & 779 \\
\hline June 2008 & 3.5 & 3.0 & 800 & 42 & 1.25 & 22.6 & 19 & 11 & 1.70 & 880 \\
\hline July 2008 & 3.6 & 3.1 & 670 & 38 & 1.30 & 22.8 & 17 & 10 & 1.65 & 805 \\
\hline August 2008 & 4.4 & 3.4 & 861 & 46 & 1.22 & 26.0 & 21 & 11 & 1.72 & 990 \\
\hline September 2008 & 4.5 & 3.2 & 689 & 41 & 1.30 & 21.2 & 18 & 12 & 1.68 & 860 \\
\hline October 2008 & 3.8 & 2.6 & 679 & 38 & 1.16 & 21.1 & 18 & 11 & 1.60 & 850 \\
\hline November 2008 & 3.8 & 2.8 & 728 & 43 & 1.40 & 21.8 & 19 & 12 & 1.66 & 861 \\
\hline December 2008 & 3.8 & 2.5 & 733 & 41 & 0.95 & 24.5 & 19 & 12 & 1.60 & 870 \\
\hline Table 1 Ceiling & & & & & & & & & & \\
\hline $\begin{array}{l}\text { Concentration Limits } \\
\text { Table } 3 \text { Pollutant }\end{array}$ & 75 & 85 & 4,300 & 840 & 57 & 75 & 420 & 100 & None & 7,500 \\
\hline Concentration Limits & 41 & 39 & 1,500 & 300 & 17 & None & 420 & 100 & None & 2,800 \\
\hline
\end{tabular}


[Data from Crock and others, 2008b and 2009a. Data are for NIST 2781, a standard reference material prepared by the National Institute of Standards and Technology from domestic sewage sludge; ppm, parts per million; \%, percent; +/-, plus or minus the analytical uncertainty; --, no value]

\begin{tabular}{|c|c|c|c|c|c|c|c|c|c|c|}
\hline $\begin{array}{c}\text { Analysis } \\
\text { date }\end{array}$ & $\begin{array}{c}\text { Arsenic, } \\
\text { ppm }\end{array}$ & $\begin{array}{c}\text { Cadmium, } \\
\text { ppm }\end{array}$ & $\begin{array}{c}\text { Copper, } \\
\text { ppm }\end{array}$ & $\begin{array}{l}\text { Lead, } \\
\text { ppm }\end{array}$ & $\begin{array}{c}\text { Mercury, } \\
\text { ppm }\end{array}$ & $\begin{array}{c}\text { Molybdenum, } \\
\text { ppm }\end{array}$ & $\begin{array}{c}\text { Nickel, } \\
\text { ppm }\end{array}$ & $\begin{array}{c}\text { Selenium, } \\
\text { ppm }\end{array}$ & $\begin{array}{c}\text { Sulfur, } \\
\%\end{array}$ & $\begin{array}{l}\text { Zinc, } \\
\text { ppm }\end{array}$ \\
\hline 2007 & 7.2 & 13.1 & 670 & 215 & 2.78 & 47.1 & 82 & 18 & 1.54 & 1310 \\
\hline 2008 & 7.3 & 12.2 & 631 & 188 & 3.35 & 40.7 & 74 & 17 & 1.59 & 1270 \\
\hline \multicolumn{11}{|c|}{ NIST 2781 Recommended or Certified Value } \\
\hline & $7.82+/-0.28$ & $12.78+/-0.72$ & $627.4+/-13.5$ & $202.1+/-6.5$ & $3.64+/-0.25$ & $46.7+/-3.2$ & $80.2+/-2.3$ & $16.0+/-1.6$ & -- & $1273+/-53$ \\
\hline
\end{tabular}


Table 5. Plutonium data for biosolids samples collected at the Metro Wastewater Reclamation District, 2007 and 2008.

[pCi/g, picocuries per gram; +/-, plus or minus the analytical uncertainty; analytical uncertainty is the 1-sigma total combined standard uncertainty provided by the laboratory]

\begin{tabular}{|c|c|c|c|c|}
\hline Sample date & Plutonium 238, pCi/g & $\begin{array}{c}\text { Plutonium 238, } \\
\text { minimum detectable } \\
\text { concentration, pCi/g }\end{array}$ & Plutonium 239+240, pCi/g & $\begin{array}{c}\text { Plutonium 239+240, minimum } \\
\text { detectable concentration, } \mathrm{pCi} / \mathrm{g}\end{array}$ \\
\hline June 2008 & $-0.003+/-0.017$ & 0.1 & $-0.0023+/-0.0034$ & 0.1 \\
\hline
\end{tabular}


[No samples were collected in 2007; sampled fields are shown in figure 4 (DC 454 field) or figure 5 (Arapahoe County fields); data are reported as dry weight; DC, Destination Code, which is shown in figure 4; ppm, parts per million; <, less than]

\begin{tabular}{|c|c|c|c|c|c|c|c|c|c|c|}
\hline Location & Sample type & $\begin{array}{c}\text { Harvest } \\
\text { year }\end{array}$ & $\begin{array}{l}\text { Arsenic, } \\
\text { ppm }\end{array}$ & $\begin{array}{c}\text { Cadmium, } \\
\text { ppm }\end{array}$ & $\begin{array}{l}\text { Copper, } \\
\text { ppm }\end{array}$ & $\begin{array}{l}\text { Lead, } \\
\text { ppm }\end{array}$ & $\begin{array}{c}\text { Mercury, } \\
\text { ppm }\end{array}$ & $\begin{array}{c}\text { Molybdenum, } \\
\text { ppm }\end{array}$ & $\begin{array}{c}\text { Nickel, } \\
\text { ppm }\end{array}$ & $\begin{array}{l}\text { Zinc, } \\
\text { ppm }\end{array}$ \\
\hline $\begin{array}{l}\text { Arapahoe County north field } \\
\text { (control) }\end{array}$ & Wheat grain & 2008 & $<0.02$ & 0.03 & 2.4 & $<0.008$ & $<0.03$ & 0.69 & 0.56 & 22.0 \\
\hline $\begin{array}{l}\text { Arapahoe County middle field } \\
\text { (biosolids applied) }\end{array}$ & Wheat grain & 2008 & $<0.02$ & 0.03 & 4.1 & $<0.008$ & $<0.03$ & 0.94 & 0.74 & 24.7 \\
\hline $\begin{array}{l}\text { Arapahoe County south field } \\
\text { (control) }\end{array}$ & Wheat grain & 2008 & $<0.02$ & 0.03 & 4.3 & $<0.008$ & $<0.03$ & 0.80 & 0.80 & 34.9 \\
\hline $\begin{array}{l}\text { Elbert County DC } 454 \text { field } \\
\text { (biosolids applied) }\end{array}$ & Corn kernels & 2008 & $<0.02$ & 0.01 & 2.0 & $<0.008$ & $<0.03$ & 0.30 & 0.30 & 23.9 \\
\hline
\end{tabular}


Table 7. Selected information for U.S. Geological Survey monitoring wells near Deer Trail, Colorado, 2007 and 2008.

[Wells shown in bold routinely are sampled for water quality; all wells have 2-inch-diameter casing; latitude and longitude are in the format degrees minutes seconds referenced to North American Datum of 1983 ; Alt., altitude in feet above North American Vertical Datum of 1988; stickup,the length of well casing above ground (fluctuates because land surface is uneven and changes height over time), and measuring point is at the top of the stickup; bmp, below measuring point; sump, the nonperforated closed casing below the screen; HUC, Hydrologic Unit Code (Seaber and others, 1987); NWIS, U.S. Geological Survey National Water Information System database; ID, identification number; Metro, Metro Wastewater Reclamation District; L, alluvial; R, bedrock; S, shallow (not known if alluvial or bedrock)]

\begin{tabular}{|c|c|c|c|c|c|c|c|c|c|c|c|c|c|c|c|c|c|}
\hline Well name & Latitude & Longitude & $\begin{array}{c}\text { Alt. of } \\
\text { stickup } \\
\text { (feet) }\end{array}$ & $\begin{array}{c}\text { Alt. of } \\
\text { land } \\
\text { surface } \\
\text { (feet) }\end{array}$ & $\begin{array}{l}\text { Property } \\
\text { owner }\end{array}$ & County & Drill date & $\begin{array}{l}\text { Measured } \\
\text { stickup }^{1} \\
\text { (feet) }\end{array}$ & $\begin{array}{l}\text { Total } \\
\text { depth } \\
\text { (feet } \\
\text { bmp) }\end{array}$ & $\begin{array}{l}\text { Depth of } \\
\text { screen top } \\
\text { (feet bmp) }\end{array}$ & $\begin{array}{c}\text { Depth of } \\
\text { screen } \\
\text { bottom (feet } \\
\text { bmp) }\end{array}$ & $\begin{array}{l}\text { Screen- } \\
\text { slot size } \\
\text { (inch) }\end{array}$ & $\begin{array}{c}\text { Screen } \\
\text { length } \\
\text { (feet) }\end{array}$ & $\begin{array}{c}\text { Sump } \\
\text { length } \\
\text { (feet) }\end{array}$ & $\begin{array}{c}\text { Aquifer } \\
\text { type }\end{array}$ & HUC & NWIS station ID \\
\hline$\overline{\text { DTX1 }}$ & 394333 & 1035251 & 4,909 & 4,906 & Metro & Arapahoe & $2 / 16 / 1999$ & 2.56 & 25.50 & 20.59 & 22.19 & 0.010 & 1.60 & 3.31 & $\mathrm{~L}$ & 10190012 & 394333103525100 \\
\hline DTX2 $^{2}$ & 394149 & 1035138 & 4,903 & 4,900 & Metro & Arapahoe & $2 / 16 / 1999$ & 3.23 & 20.50 & 15.59 & 17.19 & 0.010 & 1.60 & 3.31 & $\mathrm{~L}$ & 10190012 & 394148103513300 \\
\hline DTX3 & 393024 & 1034328 & 5,195 & 5,192 & Metro & Elbert & $2 / 12 / 1999$ & 3.11 & 18.71 & 13.80 & 15.40 & 0.010 & 1.60 & 3.31 & $\mathrm{~L}$ & 10190013 & 393024103432800 \\
\hline DTX4 & 393358 & 1034342 & 4,957 & 4,954 & Metro & Elbert & $2 / 10 / 1999$ & 2.70 & 16.72 & 11.81 & 13.41 & 0.010 & 1.60 & 3.31 & $\mathrm{~L}$ & 10190013 & 393358103434200 \\
\hline DTX5 & 393358 & 1034548 & 4,975 & 4,973 & Metro & Elbert & $2 / 10 / 1999$ & 2.30 & 20.90 & 16.09 & 17.69 & 0.010 & 1.60 & 3.21 & $\mathrm{~L}$ & 10190013 & 393358103454800 \\
\hline DTX6 & 393358 & 1034648 & 4,970 & 4,968 & Metro & Elbert & 2/9/1999 & ${ }^{3} 2.36$ & 39 & 34 & 36 & 0.010 & 1.60 & 3.31 & $\mathrm{~L}$ & 10190013 & 393358103464800 \\
\hline DTX7 & 394054 & 1035646 & 5,076 & 5,073 & Price & Arapahoe & $2 / 18 / 1999$ & 2.77 & 16.10 & 11.19 & 12.79 & 0.010 & 1.60 & 3.31 & $\mathrm{~L}$ & 10190011 & 394054103564600 \\
\hline DTX8A ${ }^{4}$ & 394054 & 1035645 & 5,076 & 5,074 & Price & Arapahoe & $3 / 2 / 1999$ & 2.46 & 77.52 & 67.56 & 71.83 & 0.010 & 4.27 & 5.69 & $\mathrm{R}$ & 10190011 & 394054103564501 \\
\hline DTX8B ${ }^{4}$ & 394054 & 1035645 & 5,076 & 5,074 & Price & Arapahoe & $3 / 2 / 1999$ & 2.49 & 177.48 & 167.52 & 171.79 & 0.010 & 4.27 & 5.69 & $\mathrm{R}$ & 10190011 & 394054103564502 \\
\hline DTX9 ${ }^{2}$ & 393902 & 1035540 & 5,121 & 5,119 & Weisensee & Arapahoe & $2 / 17 / 1999$ & 2.46 & 30.15 & 22.72 & 24.32 & 0.010 & 1.60 & 5.83 & $\mathrm{~L}$ & 10190011 & 393902103554000 \\
\hline DTX10A $\mathrm{A}^{2,4}$ & 393902 & 1035540 & 5,122 & 5,120 & Weisensee & Arapahoe & $3 / 4 / 1999$ & 2.03 & 61.97 & 52.01 & 56.28 & 0.010 & 4.27 & 5.69 & $\mathrm{R}$ & 10190011 & 393902103554001 \\
\hline DTX10B ${ }^{4}$ & 393902 & 1035540 & 5,122 & 5,120 & Weisensee & Arapahoe & $3 / 4 / 1999$ & 2.11 & 121.73 & 111.77 & 116.04 & 0.010 & 4.27 & 5.69 & $\mathrm{R}$ & 10190011 & 393902103554002 \\
\hline DTX11 $1^{2}$ & 393902 & 1035540 & $\begin{array}{l}5,122 \\
5,122\end{array}$ & 5,120 & Weisensee & Arapahoe & $1 / 19 / 2000$ & 2.24 & 32 & 28 & 30 & 0.020 & 1.85 & 2.35 & L & 10190011 & 393902103554003 \\
\hline D2 & 393647 & 1035159 & $5,172.89$ & 5,170 & Metro & Arapahoe & 9/7/1993 & 3.29 & 25 & 15 & 25 & 0.010 & 10 & $<1$ & $\mathrm{~s}$ & 10190013 & 393649103515600 \\
\hline D3 & 393721 & 1035431 & $5,191.29$ & 5,188 & Metro & Arapahoe & 9/11/1993 & 2.83 & 46 & 36 & 46 & 0.010 & 10 & $<1$ & $\mathrm{~s}$ & 10190011 & 393723103535400 \\
\hline D4 & 393641 & 1035351 & $5,212.51$ & 5,210 & Metro & Arapahoe & 9/10/1993 & 2.11 & 34 & 24 & 34 & 0.010 & 10 & $<1$ & $\mathrm{~S}$ & 10190011 & 393622103542900 \\
\hline D5 & 393619 & 1035155 & $5,198.29$ & 5,195 & Metro & Arapahoe & 9/11/1993 & 3.45 & 30 & 20 & 30 & 0.010 & 10 & $<1$ & $\mathrm{~s}$ & 10190013 & 393619103515500 \\
\hline D6 & 393633 & 1035122 & $5,128.78$ & 5,126 & Metro & Arapahoe & $9 / 12 / 1993$ & 2.65 & 25 & 15 & 25 & 0.010 & 10 & 0.3 & $\mathrm{~L}$ & 10190013 & 393633103512300 \\
\hline D6A & 393633 & 1035122 & 5,129 & 5,126 & Metro & Arapahoe & $2 / 6 / 2002$ & 2.42 & 32.96 & 28.42 & 30.71 & 0.010 & 2.29 & 2.25 & $\mathrm{~L}$ & 10190013 & 393633103512301 \\
\hline D7 & 393601 & 1035356 & $5,223.28$ & 5,221 & Metro & Arapahoe & 9/10/1993 & 2.62 & 25 & 15 & 25 & 0.010 & 10 & $<1$ & $\mathrm{~s}$ & 10190011 & 393622103540900 \\
\hline D8 & 393637 & 1035422 & 5.189 .14 & 5,186 & Metro & Arapahoe & $9 / 10 / 1993$ & 2.79 & 20 & 10 & 20 & 0.010 & 10 & $<1$ & s & 10190011 & 393637103542400 \\
\hline D10 & 393608 & 1035150 & $5,199.79$ & 5,197 & Metro & Arapahoe & $9 / 11 / 1993$ & 2.40 & 20 & 10 & 20 & 0.010 & 10 & $<1$ & $\mathrm{~s}$ & 10190013 & 393609103514600 \\
\hline D11a & 393345 & 1035423 & $\begin{array}{c}5,377 \\
5\end{array}$ & 5,374 & Metro & Elbert & $10 / 23 / 1997$ & 2.46 & 143.03 & 112.65 & 122.65 & 0.010 & 10 & 20.38 & $\mathrm{R}$ & 10190011 & 393334103543600 \\
\hline D13 & 393442 & 1035438 & $5,235.33$ & 5,234 & Metro & $\begin{array}{l}\text { Eroent } \\
\text { Arapahoe }\end{array}$ & $4 / 4 / 1994$ & $\begin{array}{l}2.40 \\
1.81\end{array}$ & $\begin{array}{c}143.03 \\
16\end{array}$ & 6 & $\begin{array}{c}12.05 \\
16\end{array}$ & 0.010 & 10 & $\begin{array}{c}20.30 \\
0.3\end{array}$ & $\begin{array}{l}\mathrm{K} \\
\mathrm{L}\end{array}$ & 10190011 & 393439103543400 \\
\hline D14 & 393429 & 1035403 & $5,272.13$ & 5,271 & Metro & Arapahoe & 4/4/1994 & 1.39 & 24 & 14 & 24 & 0.010 & 10 & $<1$ & $\mathrm{~s}$ & 10190011 & 393427103540000 \\
\hline D15 & 393359 & 1035454 & $5,246.77$ & 5,245 & Keen & Elbert & 4/7/1994 & 1.86 & 25 & 15 & 25 & 0.010 & 10 & $<1$ & $\mathrm{~s}$ & 10190011 & 393357103545200 \\
\hline D16 & 393306 & 1035456 & $\begin{array}{c}5,270,1 / 1 \\
5,279\end{array}$ & 5,277 & Keen & Elbert & $4 / 7 / 1994$ & $\begin{array}{l}1.00 \\
1.88\end{array}$ & 25 & 15 & 25 & 0.010 & 10 & $<1$ & S & 10190011 & 393307103545500 \\
\hline $\begin{array}{l}\text { D17 } \\
\text { D17 }\end{array}$ & 393334 & $\begin{array}{l}1035450 \\
1035436\end{array}$ & $\begin{array}{c}5,277.73 \\
5,273\end{array}$ & 5,276 & $\begin{array}{l}\text { Reen } \\
\text { Metro }\end{array}$ & $\begin{array}{l}\text { Elbert } \\
\text { Elbert }\end{array}$ & $\begin{array}{l}4 / 5 / 1994 \\
4 / 5 / 1994\end{array}$ & $\begin{array}{l}1.88 \\
1.90\end{array}$ & 21 & 11 & 21 & 0.010 & 10 & 0.3 & $\mathrm{~L}$ & 10190011 & 393327103541200 \\
\hline D18 & 393329 & 1035520 & 5,298 & 5,295 & Keen & Elbert & $4 / 16 / 1994$ & 2.50 & 15 & 10 & 15 & 0.010 & 5 & $<1$ & $\mathrm{~s}$ & 10190011 & 393325103552500 \\
\hline D19 & 393317 & 1035418 & $5,304.24$ & 5,303 & Metro & Elbert & $4 / 5 / 1994$ & 1.69 & 30 & 20 & 30 & 0.010 & 10 & 0.3 & $\mathrm{R}$ & 10190011 & 393311103541800 \\
\hline D20 & 393246 & 1035442 & 5,282 & 5,28 & $\mathrm{Ke}$ & $\mathrm{Elb}$ & $4 / 6 / 1994$ & 2 & 22 & 1 & 22 & 0010 & 10 & $<1$ & s & 10190011 & 393247103543800 \\
\hline D21 & 393209 & 1035446 & $\begin{array}{l}5,202 \\
5,319\end{array}$ & 5,317 & Keen & Elbert & $4 / 5 / 1994$ & 1.71 & 20 & 10 & 20 & 0.010 & 10 & $<1$ & $\mathrm{~s}$ & 10190011 & 393207103544800 \\
\hline D22 & 393308 & 1035200 & $5,157.66$ & 5,154 & Metro & Elbert & $4 / 8 / 1994$ & 3.58 & 41 & 31 & 41 & 0.010 & 10 & $<1$ & S & 10190013 & 393307103515900 \\
\hline D23 & 393342 & 1035501 & $5,256.05$ & 5,254 & Keen & Elbert & $4 / 8 / 1994$ & 2.54 & 15 & 10 & 15 & 0.010 & 5 & $<1$ & $\mathrm{~s}$ & 10190011 & 393330103545300 \\
\hline D25 & 393702 & 1035442 & $5,167.13$ & 5,165 & Metro & Arapahoe & $5 / 1 / 1995$ & 2.23 & 23 & 13 & 23 & 0.010 & 10 & 0.3 & $\mathrm{~L}$ & 10190011 & 393702103544100 \\
\hline $\mathrm{D} 25 \mathrm{~A}$ & 393702 & 1035442 & 5,167 & 5,165 & Metro & Arapahoe & 2/5/2002 & 2.28 & 24.39 & 19.85 & 22.14 & 0.010 & 2.29 & 2.25 & $\mathrm{~L}$ & 10190011 & 393702103544102 \\
\hline D26 & 393640 & 1035330 & $5,233.34$ & 5,231 & Metro & Arapahoe & $5 / 3 / 1995$ & 2.44 & 44 & 34 & 44 & 0.010 & 10 & $<1$ & $\mathrm{~s}$ & 10190011 & 393639103533000 \\
\hline $\begin{array}{l}\text { D20 } \\
\text { D27 }\end{array}$ & 393621 & 1035409 & $\begin{array}{l}5,23.34 \\
5,207.20\end{array}$ & $\begin{array}{l}\quad, 2,21 \\
5,204\end{array}$ & Metro & $\begin{array}{l}\text { Arapanoe } \\
\text { Araphe }\end{array}$ & $\begin{array}{l}5 / 2 / 1995 \\
5 / 2195\end{array}$ & $\begin{array}{l}2.44 \\
2.77\end{array}$ & $\begin{array}{l}44 \\
26\end{array}$ & $\begin{array}{l}34 \\
16\end{array}$ & $\begin{array}{l}44 \\
26\end{array}$ & 0.010 & 10 & $<1$ & s & 10190011 & 393621103540900 \\
\hline D28 & 393545 & 1035340 & $5,239.11$ & 5,237 & Metro & Arapahoe & $5 / 2 / 1995$ & 2.12 & 30 & 20 & 30 & 0.010 & 10 & $<1$ & $\mathrm{~s}$ & 10190011 & 393545103534000 \\
\hline D29 & 393641 & 1035248 & 5,371 & 5,369 & Metro & Arapahoe & $11 / 4 / 1997$ & 2.38 & 183.19 & 147.81 & 157.81 & 0.010 & 10 & 25.38 & $\mathrm{R}$ & 10190013 & 393632103524300 \\
\hline D $30^{5}$ & 393655 & 1035122 & $5,096.43$ & 5,094 & Metro & Arapahoe & $5 / 5 / 1995$ & 2 & 19 & 9 & 19 & 0.010 & 10 & 0.3 & $\mathrm{~L}$ & 10190013 & 393655103512200 \\
\hline D31 & 393656 & 1035139 & $5,119.76$ & 5,118 & Metro & Arapahoe & $5 / 4 / 1995$ & 1.84 & 26 & 11 & 21 & 0.010 & 10 & 5 & $\mathrm{~L}$ & 10190013 & 393656103513900 \\
\hline $\begin{array}{l}\text { D31 } \\
\text { D32 }\end{array}$ & $\begin{array}{l}593050 \\
393609\end{array}$ & 1035126 & $\begin{array}{l}5,119.10 \\
5,188.93\end{array}$ & $\begin{array}{l}5,118 \\
5,187\end{array}$ & Metro & Arapahoe & $\begin{array}{l}5 / 4 / 19995 \\
5 / 9 / 1995\end{array}$ & $\begin{array}{l}1.84 \\
1.99\end{array}$ & $\begin{array}{l}260 \\
40\end{array}$ & $\begin{array}{l}11 \\
30\end{array}$ & 40 & 0.010 & 10 & $<1$ & S & 10190013 & 393609103513900 \\
\hline$D 33$ & 393556 & 1035153 & $5,229.08$ & 5,227 & Metro & Aranahoe & $5 / 5 / 1995$ & 1.73 & 25 & 10 & 20 & 0.010 & 10 & 5 & L & 10190013 & 393556103515300 \\
\hline
\end{tabular}

Stickup measured at a specific date and time soon after well was installed, but this measurement is relative to land surface, which is not uniform or constant over time.

'Well had continuous-recorder equipment any time during 2007 and 2008

DTX6 stickup went from 2.43 to 2.36 feet between mid-October 2002 and early November 2002 when well was vandalized.

DTX8 and DTX10 are nested wells that consist of a single borehole that has two separate piezometers screened at two separate zones; the shallow zone is designated by "A" and the deep zone is designated by "B" after the well name.

Well D30 was closed 9/5/2008 because of damages. 
Table 8. Methods used to analyze groundwater samples collected near Deer Trail, Colorado, 2007 and 2008.

[MRL, minimum reporting level (dilutions for samples having high specific conductance may result in higher MRLs for some samples); $\mu \mathrm{S} / \mathrm{cm}, \mathrm{microsiemens}$ per centimeter at $25^{\circ} \mathrm{C} ; \mathrm{mg} / \mathrm{L}$ milligrams per liter; ICP, inductively coupled plasma; AES, atomic-emission spectrometry; IC, ion chromatography; ${ }^{\circ} \mathrm{C}$, degrees Celsius; ASF, automated segmented-flow spectrophotometry; $\mu \mathrm{g} / \mathrm{L}$, micrograms per liter; MS, mass spectroscopy; cICP, collision-cell inductively coupled plasma; CVAF, cold-vapor atomic fluorescence spectrometry]

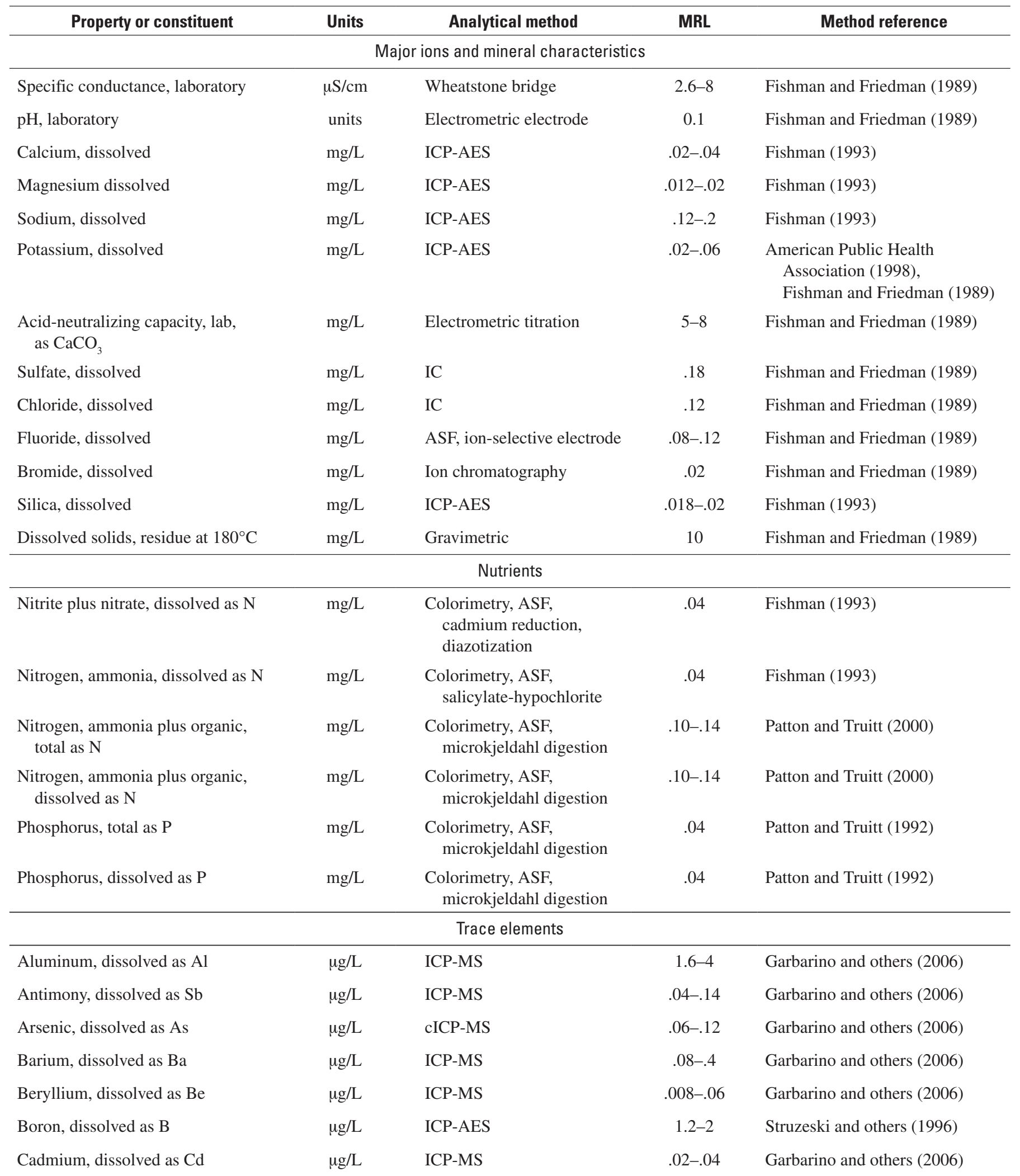


Table 8. Methods used to analyze groundwater samples collected near Deer Trail, Colorado, 2007 and 2008.—Continued

[MRL, minimum reporting level (dilutions for samples having high specific conductance may result in higher MRLs for some samples); $\mu \mathrm{S} / \mathrm{cm}$, microsiemens per centimeter at $25^{\circ} \mathrm{C} ; \mathrm{mg} / \mathrm{L}$ milligrams per liter; ICP, inductively coupled plasma; AES, atomic-emission spectrometry; IC, ion chromatography; ${ }^{\circ} \mathrm{C}$, degrees Celsius; ASF, automated segmented-flow spectrophotometry; $\mu \mathrm{g} / \mathrm{L}$, micrograms per liter; MS, mass spectroscopy; cICP, collision-cell inductively coupled plasma; CVAF, cold-vapor atomic fluorescence spectrometry]

\begin{tabular}{|c|c|c|c|c|}
\hline Property or constituent & Units & Analytical method & MRL & Method reference \\
\hline Chromium, dissolved as $\mathrm{Cr}$ & $\mu \mathrm{g} / \mathrm{L}$ & cICP-MS & .12 & Garbarino and others (2006) \\
\hline Cobalt, dissolved as Co & $\mu \mathrm{g} / \mathrm{L}$ & cICP-MS & $.02-.04$ & Garbarino and others (2006) \\
\hline Copper, dissolved as $\mathrm{Cu}$ & $\mu \mathrm{g} / \mathrm{L}$ & cICP-MS & .4-1 & Garbarino and others (2006) \\
\hline Iron, dissolved as $\mathrm{Fe}$ & $\mu \mathrm{g} / \mathrm{L}$ & ICP-AES & $4-8$ & Fishman (1993) \\
\hline Lead, dissolved as $\mathrm{Pb}$ & $\mu \mathrm{g} / \mathrm{L}$ & ICP-MS & $.06-.12$ & Garbarino and others (2006) \\
\hline Manganese, dissolved as Mn & $\mu \mathrm{g} / \mathrm{L}$ & ICP-MS & .2 & Garbarino and others (2006) \\
\hline Mercury, dissolved as $\mathrm{Hg}$ & $\mu \mathrm{g} / \mathrm{L}$ & CVAF & .01 & Gabarino and Damrau (2001) \\
\hline Molybdenum, dissolved as Mo & $\mu \mathrm{g} / \mathrm{L}$ & ICP-MS & $.02-.12$ & Garbarino and others (2006) \\
\hline Nickel, dissolved as Ni & $\mu \mathrm{g} / \mathrm{L}$ & cICP-MS & $.06-.2$ & Garbarino and others (2006) \\
\hline Selenium, dissolved as $\mathrm{Se}$ & $\mu \mathrm{g} / \mathrm{L}$ & cICP-MS & $.04-.08$ & Garbarino and others (2006) \\
\hline Silver, dissolved as Ag & $\mu \mathrm{g} / \mathrm{L}$ & ICP-MS & $.008-.1$ & Garbarino and others (2006) \\
\hline Strontium, dissolved as $\mathrm{Sr}$ & $\mu \mathrm{g} / \mathrm{L}$ & ICP-AES & $.4-.6$ & Fishman (1993) \\
\hline Tungsten, dissolved as $\mathrm{W}$ & $\mu \mathrm{g} / \mathrm{L}$ & cICP-MS & $.02-.06$ & Garbarino and others (2006) \\
\hline Zinc, dissolved as $\mathrm{Zn}$ & $\mu \mathrm{g} / \mathrm{L}$ & cICP-MS & $.6-.2$ & Garbarino and others (2006) \\
\hline \multicolumn{5}{|c|}{ Radioactivity } \\
\hline Uranium, natural, dissolved & $\mu \mathrm{g} / \mathrm{L}$ & ICP-MS & 然-.04 & Garbarino and others (2006) \\
\hline
\end{tabular}


[Uncertainty of the depth-to-water measurements is 0.02 foot or less. No access to wells January and February of 2007 due to weather; W.L. bmp, depth to water level below measuring point, in feet, measured with an electric tape; --, no data; *, water level is below the screened interval of the well; closed, well was closed 9/5/08]

\begin{tabular}{|c|c|c|c|c|c|c|c|c|c|c|c|}
\hline Well name & $\begin{array}{c}\text { March } \\
(3 / 14 / 2007) \\
\text { W.L. bmp }\end{array}$ & $\begin{array}{c}\text { April } \\
(4 / 11 / 2007) \\
\text { W.L. bmp }\end{array}$ & $\begin{array}{c}\text { May } \\
(5 / 30 / 2007- \\
5 / 31 / 2007) \\
\text { W.L. bmp }\end{array}$ & $\begin{array}{c}\text { June } \\
(06 / 28 / 2007- \\
\text { 6/29/2007) } \\
\text { W.L. bmp }\end{array}$ & $\begin{array}{c}\text { July } \\
\text { (7/25/2007) } \\
\text { W.L. bmp } \\
\end{array}$ & $\begin{array}{c}\text { August } \\
(08 / 14 / 2007) \\
\text { W.L. bmp }\end{array}$ & $\begin{array}{c}\text { September } \\
(09 / 12 / 2007) \\
\text { W.L. bmp }\end{array}$ & $\begin{array}{c}\text { October } \\
(10 / 10 / 2007) \\
\text { W.L. bmp }\end{array}$ & $\begin{array}{c}\text { November } \\
(11 / 07 / 2007) \\
\text { W.L. bmp }\end{array}$ & $\begin{array}{c}\text { December } \\
(12 / 19 / 2007) \\
\text { W.L. bmp }\end{array}$ & $\begin{array}{c}\text { January } \\
(1 / 15 / 2008) \\
\text { W.L. bmp }\end{array}$ \\
\hline DTX1 & 14.30 & 14.23 & 14.29 & 14.38 & 14.47 & 13.37 & 13.50 & 13.59 & 13.70 & 13.85 & 13.93 \\
\hline DTX2 & 11.13 & 11.03 & 10.89 & 11.24 & 11.85 & 11.84 & 11.97 & 11.96 & 11.74 & 11.59 & 11.53 \\
\hline DTX3 & * & * & * & * & * & * & * & * & * & * & * \\
\hline DTX4 & 8.07 & 8.71 & 9.15 & 5.80 & 8.33 & 9.08 & 9.55 & 10.21 & 10.27 & 10.44 & No Access \\
\hline DTX5 & -- & -- & 6.98 & 4.89 & 7.10 & 8.22 & 9.17 & 9.83 & 10.02 & 10.21 & 10.27 \\
\hline DTX6 & 19.71 & 20.69 & 20.29 & 20.13 & 20.71 & 20.45 & 20.35 & 20.84 & 21.10 & 21.39 & 21.49 \\
\hline DTX7 & 8.30 & 8.40 & 8.38 & 9.13 & 9.68 & 9.71 & 9.87 & 9.94 & 9.65 & 9.42 & 9.29 \\
\hline DTX8A & 8.59 & 8.55 & 8.69 & 9.58 & 10.46 & 10.27 & 10.44 & 10.44 & 10.43 & 9.73 & 9.51 \\
\hline DTX8B & 4.93 & 4.93 & 5.04 & 5.15 & 5.23 & 5.21 & 5.22 & 5.25 & 5.27 & 5.19 & 5.16 \\
\hline DTX9 & 13.58 & 13.43 & 13.24 & 13.49 & 13.55 & 13.60 & 13.66 & 13.74 & 13.76 & 13.78 & 13.77 \\
\hline DTX10A & 13.70 & 13.52 & 13.37 & 13.61 & 13.79 & 13.85 & 13.91 & 14.02 & 14.01 & 14.04 & 14.01 \\
\hline DTX10B & 18.01 & 18.11 & 18.20 & 18.32 & 18.44 & 18.42 & 18.40 & 18.43 & 18.42 & 18.33 & 18.24 \\
\hline DTX11 & 13.93 & 13.77 & 13.59 & 13.72 & 13.89 & 13.95 & 14.01 & 14.17 & 14.09 & 14.13 & 14.10 \\
\hline D2 & -- & -- & -- & -- & -- & -- & -- & -- & -- & -- & -- \\
\hline D3 & -- & -- & -- & -- & -- & -- & -- & -- & -- & -- & -- \\
\hline D4 & -- & -- & -- & -- & -- & -- & -- & -- & -- & -- & -- \\
\hline D5 & -- & -- & -- & -- & -- & -- & -- & -- & 17.09 & - & -- \\
\hline D6 & 8.00 & 8.10 & 7.95 & 8.36 & 8.76 & 8.13 & 8.15 & 8.64 & 8.86 & 9.12 & 9.16 \\
\hline D6A & 8.01 & 7.85 & 7.75 & 8.21 & 8.61 & 7.71 & 8.00 & 8.51 & 8.72 & 8.97 & 9.02 \\
\hline D7 & -- & -- & -- & -- & -- & -- & -- & -- & -- & -- & -- \\
\hline D8 & -- & -- & -- & -- & -- & -- & -- & -- & -- & -- & -- \\
\hline D10 & -- & -- & -- & -- & -- & -- & -- & -- & 9.46 & -- & -- \\
\hline D11a & 113.48 & 113.63 & 113.78 & 113.64 & 113.60 & 113.63 & 113.49 & 113.61 & 113.55 & 113.61 & 113.33 \\
\hline D13 & 6.75 & 6.94 & 7.24 & 8.11 & 8.89 & 8.74 & 9.06 & 9.16 & 8.72 & 8.33 & 8.13 \\
\hline D14 & -- & -- & -- & -- & -- & -- & -- & -- & -- & -- & -- \\
\hline
\end{tabular}


Table 9. Monthly depth-to-water data for U.S. Geological Survey monitoring wells near Deer Trail, Colorado, 2007 and 2008.—Continued

[Uncertainty of the depth-to-water measurements is 0.02 foot or less. No access to wells January and February of 2007 due to weather; W.L. bmp, depth to water level below measuring point, in feet, measured with an electric tape; --, no data; ${ }^{*}$, water level is below the screened interval of the welli closed, well was closed 9/5/08]

\begin{tabular}{|c|c|c|c|c|c|c|c|c|c|c|c|}
\hline Well name & $\begin{array}{c}\text { March } \\
(3 / 14 / 2007) \\
\text { W.L. bmp }\end{array}$ & $\begin{array}{c}\text { April } \\
\text { (4/11/2007) } \\
\text { W.L. bmp }\end{array}$ & $\begin{array}{c}\text { May } \\
(5 / 30 / 2007- \\
\mathbf{5 / 3 1 / 2 0 0 7 )} \\
\text { W.L. bmp }\end{array}$ & $\begin{array}{c}\text { June } \\
(06 / 28 / 2007- \\
6 / 29 / 2007) \\
\text { W.L. bmp }\end{array}$ & $\begin{array}{c}\text { July } \\
\text { (7/25/2007) } \\
\text { W.L. bmp }\end{array}$ & $\begin{array}{c}\text { August } \\
\text { (08/14/2007) } \\
\text { W.L. bmp }\end{array}$ & $\begin{array}{c}\text { September } \\
\text { (09/12/2007) } \\
\text { W.L. bmp }\end{array}$ & $\begin{array}{c}\text { October } \\
(10 / 10 / 2007) \\
\text { W.L. bmp }\end{array}$ & $\begin{array}{c}\text { November } \\
(11 / 07 / 2007) \\
\text { W.L. bmp }\end{array}$ & $\begin{array}{c}\text { December } \\
(12 / 19 / 2007) \\
\text { W.L. bmp }\end{array}$ & $\begin{array}{c}\text { January } \\
(1 / 15 / 2008) \\
\text { W.L. bmp }\end{array}$ \\
\hline D15 & -- & -- & -- & -- & -- & - & -- & -- & -- & -- & -- \\
\hline D16 & -- & -- & -- & -- & -- & -- & -- & -- & -- & -- & -- \\
\hline D17 & 12.83 & 12.54 & 11.96 & 11.94 & 12.25 & 12.56 & 13.10 & 13.26 & 13.26 & 13.22 & 13.19 \\
\hline D18 & -- & -- & -- & -- & -- & -- & -- & -- & -- & -- & -- \\
\hline D19 & 22.59 & 22.61 & 22.61 & 22.61 & 22.60 & 22.57 & 22.55 & 22.58 & 22.57 & 22.59 & 22.58 \\
\hline D20 & -- & -- & -- & -- & -- & -- & -- & -- & -- & -- & -- \\
\hline D21 & -- & -- & -- & -- & -- & -- & -- & -- & -- & -- & -- \\
\hline D22 & -- & -- & -- & -- & -- & -- & -- & -- & -- & -- & -- \\
\hline D23 & -- & -- & -- & -- & -- & -- & -- & -- & -- & -- & -- \\
\hline D25 & 10.28 & 10.35 & 10.41 & 10.81 & 11.33 & 11.61 & 11.79 & 12.17 & 12.19 & 12.13 & 12.10 \\
\hline $\mathrm{D} 25 \mathrm{~A}$ & 10.21 & -- & 10.32 & 10.71 & 11.23 & 11.51 & 11.78 & 12.07 & 12.09 & 12.05 & 12.01 \\
\hline D26 & -- & -- & -- & -- & -- & -- & -- & -- & -- & -- & -- \\
\hline D27 & -- & -- & -- & -- & -- & -- & -- & -- & -- & -- & -- \\
\hline D28 & -- & -- & -- & -- & -- & -- & -- & -- & -- & -- & -- \\
\hline D29 & 153.88 & 153.74 & 154.07 & 154.07 & 153.83 & 153.95 & 153.80 & 153.96 & 153.83 & 153.67 & 153.60 \\
\hline D30 & 4.00 & 4.17 & 4.43 & 5.55 & 6.02 & 5.65 & 6.02 & 6.07 & 5.90 & 5.51 & 5.23 \\
\hline D31 & -- & -- & -- & -- & -- & -- & -- & -- & -- & -- & -- \\
\hline D32 & -- & -- & -- & -- & -- & -- & -- & -- & 29.08 & -- & -- \\
\hline D33 & -- & -- & -- & -- & -- & -- & -- & -- & 12.39 & -- & -- \\
\hline
\end{tabular}


[Uncertainty of the depth-to-water measurements is 0.02 foot or less. No access to wells January and February of 2007 due to weather; W.L. bmp, depth to water level below measuring point, in feet, measured with an electric tape; --, no data; ${ }^{\text {, }}$, water level is below the screened interval of the well; closed, well was closed 9/5/08]

\begin{tabular}{|c|c|c|c|c|c|c|c|c|c|c|c|}
\hline Well name & $\begin{array}{c}\text { February } \\
(2 / 25 / 2008) \\
\text { W.L. bmp }\end{array}$ & $\begin{array}{c}\text { March } \\
(3 / 10 / 2008) \\
\text { W.L. bmp }\end{array}$ & $\begin{array}{c}\text { April } \\
(4 / 9 / 2008) \\
\text { W.L. bmp }\end{array}$ & $\begin{array}{c}\text { May } \\
(5 / 9 / 2008) \\
\text { W.L. bmp }\end{array}$ & $\begin{array}{c}\text { June } \\
(6 / 13 / 2008) \\
\text { W.L. bmp }\end{array}$ & $\begin{array}{c}\text { July } \\
\text { (7/7/2008) } \\
\text { W.L. bmp }\end{array}$ & $\begin{array}{c}\text { August } \\
(8 / 20 / 2008- \\
8 / 28 / 2008) \\
\text { W.L. bmp }\end{array}$ & $\begin{array}{l}\text { September } \\
(9 / 17 / 2008- \\
9 / 30 / 2008) \\
\text { W.L. bmp }\end{array}$ & $\begin{array}{c}\text { October } \\
(10 / 16 / 2008) \\
\text { W.L. bmp }\end{array}$ & $\begin{array}{c}\text { November } \\
(11 / 7 / 2008) \\
\text { W.L. bmp }\end{array}$ & $\begin{array}{c}\text { December } \\
(12 / 12 / 2008) \\
\text { W.L. bmp }\end{array}$ \\
\hline DTX1 & 14.07 & 14.11 & 14.11 & 14.15 & 14.26 & 14.39 & 14.40 & 14.33 & 14.44 & 14.46 & 14.47 \\
\hline DTX2 & 11.54 & 11.50 & 11.43 & 11.38 & 11.51 & 11.79 & 8.19 & 8.86 & 9.31 & 9.46 & 9.53 \\
\hline DTX3 & * & * & * & * & * & * & * & * & * & * & * \\
\hline DTX4 & 10.81 & 10.90 & 10.88 & 11.08 & 11.70 & 11.17 & 10.09 & 11.01 & 11.55 & 11.72 & 11.78 \\
\hline DTX5 & 10.64 & 10.70 & 10.62 & 10.68 & 10.93 & 11.10 & 9.95 & 10.41 & 10.76 & 10.89 & 10.96 \\
\hline DTX6 & 21.71 & 21.76 & 21.81 & 21.93 & 22.30 & 21.29 & 20.91 & 21.13 & 21.41 & 21.52 & 21.66 \\
\hline DTX7 & 9.19 & 9.15 & 9.03 & 8.99 & 9.42 & 9.91 & 8.71 & 9.24 & 9.19 & 9.11 & 8.93 \\
\hline DTX8A & 9.45 & 9.42 & 9.26 & 9.30 & 9.82 & 10.19 & 9.33 & 9.60 & 9.47 & 9.69 & 9.43 \\
\hline DTX8B & 5.16 & 5.23 & 5.16 & 5.16 & 5.21 & 5.24 & 4.87 & 5.13 & 5.13 & 5.13 & 5.09 \\
\hline DTX9 & 13.88 & 13.88 & 13.83 & 13.85 & 13.96 & 14.05 & 13.80 & 13.68 & 13.68 & 13.67 & 13.65 \\
\hline DTX10A & 14.10 & 14.13 & 14.08 & 14.10 & 14.23 & 14.31 & 13.91 & 13.92 & 13.92 & 13.93 & 13.91 \\
\hline DTX10B & 18.25 & 18.25 & 18.18 & 18.17 & 18.25 & 18.32 & 17.90 & 18.35 & 18.40 & 18.45 & 18.37 \\
\hline DTX11 & 14.21 & 14.22 & 14.16 & 14.18 & 14.29 & 14.38 & 14.15 & 14.02 & 14.02 & 14.01 & 14.01 \\
\hline $\mathrm{D} 2$ & -- & -- & -- & -- & -- & -- & 10.80 & -- & -- & -- & -- \\
\hline D3 & -- & -- & -- & -- & -- & -- & 39.72 & -- & -- & -- & -- \\
\hline D4 & -- & -- & -- & -- & -- & -- & 26.19 & -- & -- & -- & -- \\
\hline D5 & -- & -- & -- & -- & -- & -- & -- & -- & -- & -- & -- \\
\hline D6 & 9.46 & 9.51 & 9.48 & 9.53 & 9.61 & 9.71 & 9.31 & 9.08 & 9.27 & 9.39 & 9.50 \\
\hline D6A & 9.31 & 9.43 & 9.29 & 9.37 & 9.49 & 9.54 & 9.20 & 9.18 & 9.17 & 9.32 & 9.42 \\
\hline D7 & -- & -- & -- & -- & -- & -- & 9.29 & -- & -- & -- & -- \\
\hline D8 & -- & -- & -- & -- & -- & -- & 10.05 & -- & -- & -- & -- \\
\hline D10 & -- & -- & -- & -- & -- & -- & -- & -- & -- & -- & -- \\
\hline D11a & 113.88 & 113.88 & 113.52 & 113.74 & 113.96 & 113.79 & 113.73 & 113.89 & 113.98 & 113.93 & 113.65 \\
\hline D13 & 7.91 & 7.82 & 7.67 & 7.59 & 7.81 & 8.22 & 7.48 & 8.08 & 8.08 & 8.00 & 7.77 \\
\hline D14 & -- & -- & -- & -- & -- & -- & 12.21 & -- & -- & -- & -- \\
\hline
\end{tabular}


Table 9. Monthly depth-to-water data for U.S. Geological Survey monitoring wells near Deer Trail, Colorado, 2007 and 2008.—Continued

[Uncertainty of the depth-to-water measurements is 0.02 foot or less. No access to wells January and February of 2007 due to weather; W.L. bmp, depth to water level below measuring point, in feet, measured with an electric tape; --, no data; ${ }^{*}$, water level is below the screened interval of the well; closed, well was closed 9/5/08]

\begin{tabular}{|c|c|c|c|c|c|c|c|c|c|c|c|}
\hline Well name & $\begin{array}{c}\text { February } \\
(2 / 25 / 2008) \\
\text { W.L. bmp } \\
\end{array}$ & $\begin{array}{c}\text { March } \\
(3 / 10 / 2008) \\
\text { W.L. bmp } \\
\end{array}$ & $\begin{array}{c}\text { April } \\
\text { (4/9/2008) } \\
\text { W.L. bmp } \\
\end{array}$ & $\begin{array}{c}\text { May } \\
(5 / 9 / 2008) \\
\text { W.L. bmp }\end{array}$ & $\begin{array}{c}\text { June } \\
(6 / 13 / 2008) \\
\text { W.L. bmp } \\
\end{array}$ & $\begin{array}{c}\text { July } \\
(7 / 7 / 2008) \\
\text { W.L. bmp } \\
\end{array}$ & $\begin{array}{c}\text { August } \\
(8 / 20 / 2008- \\
8 / 28 / 2008) \\
\text { W.L. bmp } \\
\end{array}$ & $\begin{array}{l}\text { September } \\
(9 / 17 / 2008- \\
9 / 30 / 2008) \\
\text { W.L. bmp } \\
\end{array}$ & $\begin{array}{c}\text { October } \\
(10 / 16 / 2008) \\
\text { W.L. bmp }\end{array}$ & $\begin{array}{c}\text { November } \\
(11 / 7 / 2008) \\
\text { W.L. bmp } \\
\end{array}$ & $\begin{array}{c}\text { December } \\
(12 / 12 / 2008) \\
\text { W.L. bmp } \\
\end{array}$ \\
\hline $\bar{D} 15$ & -- & -- & - & - & - & -- & 8.05 & -- & - & - & - \\
\hline D16 & -- & -- & -- & -- & -- & -- & 9.20 & -- & -- & -- & -- \\
\hline D17 & 13.12 & 13.12 & 13.07 & 13.03 & 13.01 & 13.13 & 13.09 & 13.09 & 13.14 & 13.13 & 13.10 \\
\hline D18 & -- & -- & -- & -- & -- & -- & * & -- & -- & -- & -- \\
\hline D19 & 22.61 & 22.63 & 22.64 & 22.65 & 22.67 & 22.68 & 22.70 & 22.70 & 22.73 & 22.72 & 22.73 \\
\hline D20 & -- & -- & -- & -- & -- & -- & 10.40 & -- & -- & -- & -- \\
\hline D21 & -- & -- & -- & -- & -- & -- & 11.27 & -- & -- & -- & -- \\
\hline $\mathrm{D} 22$ & -- & -- & -- & -- & -- & -- & -- & 18.21 & -- & -- & -- \\
\hline D23 & -- & -- & -- & -- & -- & -- & 6.05 & -- & -- & -- & -- \\
\hline D25 & 12.06 & 12.07 & 11.99 & 11.97 & 12.18 & 12.41 & 12.39 & 12.73 & 12.76 & 12.63 & 12.46 \\
\hline D25A & 11.99 & 11.98 & 11.91 & 11.91 & 12.09 & 12.31 & 12.31 & 12.62 & 12.66 & 12.51 & 12.35 \\
\hline D26 & -- & -- & -- & -- & -- & -- & 33.23 & -- & -- & -- & -- \\
\hline D27 & -- & -- & -- & -- & -- & -- & 10.31 & -- & -- & -- & -- \\
\hline $\mathrm{D} 28$ & -- & -- & -- & -- & -- & -- & 12.81 & -- & -- & -- & -- \\
\hline D29 & 153.90 & 154.16 & 153.54 & 153.73 & 154.10 & 153.80 & 153.65 & 153.65 & 153.92 & 153.76 & 153.62 \\
\hline D30 & 4.98 & 4.92 & 4.81 & 4.73 & 4.96 & 5.48 & 3.31 & closed & closed & closed & closed \\
\hline D31 & -- & -- & -- & -- & -- & -- & 3.93 & -- & -- & -- & -- \\
\hline D32 & -- & -- & -- & -- & -- & -- & -- & -- & -- & -- & -- \\
\hline D33 & -- & -- & -- & -- & -- & -- & -- & -- & -- & -- & -- \\
\hline
\end{tabular}



minimum reporting level; $<$, less than; $M$, presence verilied at very small concentration 25 cesild nol be quantified

\begin{tabular}{|c|c|c|c|c|c|c|c|c|c|c|c|c|c|c|}
\hline Well name & $\begin{array}{c}\text { Sample } \\
\text { date }\end{array}$ & $\begin{array}{c}\text { Sample } \\
\text { time } \\
(\mathrm{hhmm})\end{array}$ & $\begin{array}{c}\text { Air } \\
\text { temperature } \\
\left({ }^{\circ} \mathrm{C}\right)\end{array}$ & $\begin{array}{c}\text { Depth to water } \\
\text { below } \\
\text { measuring point } \\
\text { before sampling } \\
\text { (feet) }\end{array}$ & $\begin{array}{l}\text { Oxygen, } \\
\text { dissolved } \\
\text { (mg/L) }\end{array}$ & $\begin{array}{c}\text { pH, field } \\
\text { (standard } \\
\text { units) }\end{array}$ & $\begin{array}{c}\text { Specific } \\
\text { conductance, } \\
\text { field }(\mu \mathrm{S} / \mathrm{cm})\end{array}$ & $\begin{array}{c}\text { Water } \\
\text { temperature } \\
\left({ }^{\circ} \mathrm{C}\right) \\
\end{array}$ & $\begin{array}{l}\text { Acid neutralizing } \\
\text { capacity, titration, } \\
\text { field }(\mathrm{mg} / \mathrm{L} \text { as } \\
\left.\mathrm{CaCO}_{3}\right)\end{array}$ & $\begin{array}{c}\mathrm{pH}, \\
\text { laboratory } \\
\text { (standard } \\
\text { units) } \\
\end{array}$ & $\begin{array}{c}\text { Specific } \\
\text { conductance, } \\
\text { laboratory } \\
(\mu \mathrm{S} / \mathrm{cm}) \\
\end{array}$ & $\begin{array}{l}\text { Hardness, } \\
\text { total }(\mathbf{m g} / \mathrm{L} \\
\left.\text { as } \mathrm{CaCO}_{3}\right)\end{array}$ & $\begin{array}{l}\text { Calcium, } \\
\text { dissolved } \\
(\mathrm{mg} / \mathrm{L})\end{array}$ & $\begin{array}{c}\text { Magnesium, } \\
\text { dissolved } \\
(\mathrm{mg} / \mathrm{L})\end{array}$ \\
\hline DTX1 & 3/20/2007 & 1145 & 20 & 14.26 & 0.5 & 7.0 & 4,000 & 11.8 & 291 & 7.2 & 4,030 & 2,000 & 463 & 194 \\
\hline DTX1 & 6/25/2007 & 1340 & 40 & 14.38 & .4 & 7.2 & 4,110 & 12.9 & 299 & 7.0 & 4,060 & 2,000 & 467 & 191 \\
\hline DTX1 & 9/7/2007 & 0915 & 16.5 & 13.52 & .6 & 6.8 & 4,050 & 11.9 & 275 & 6.8 & 4,030 & 1,900 & 465 & 184 \\
\hline DTX1 & $11 / 20 / 2007$ & 0915 & 0 & 13.76 & .4 & 6.9 & 4,050 & 11.8 & 263 & 7.3 & 4,020 & 1,900 & 463 & 190 \\
\hline DTX1 & 3/25/2008 & 1000 & 11 & 14.12 & .4 & 7.1 & 4,090 & 11.6 & 288 & 7.3 & 4,050 & 1,900 & 463 & 190 \\
\hline DTX1 & 6/25/2008 & 1415 & -- & 14.34 & .4 & 6.8 & 4,190 & 12.5 & '281 & 7.2 & 3,930 & 2,000 & 479 & 197 \\
\hline DTX1 & 9/17/2008 & 1000 & 21.5 & 14.33 & .4 & 7.0 & 4,080 & 12.3 & ${ }^{1} 275$ & 7.2 & 4,040 & 2,000 & 479 & 198 \\
\hline DTX1 & $11 / 18 / 2008$ & 1015 & 19.5 & 14.47 & .5 & 6.9 & 4,080 & 13.3 & ${ }^{1} 286$ & 7.2 & 4,080 & 2,000 & 485 & 200 \\
\hline DTX2 & 3/20/2007 & 0930 & -- & 11.09 & .6 & 6.8 & 5,180 & 9.5 & 412 & 7.1 & 5,290 & 2,200 & 509 & 221 \\
\hline DTX2 & 6/25/2007 & 1045 & 29 & 11.2 & .7 & 7.1 & 5,500 & 11.6 & 422 & 7.2 & 5,390 & 2,100 & 488 & 212 \\
\hline DTX2 & 9/7/2007 & 1125 & 24.5 & 11.96 & .6 & 6.7 & 5,100 & 12.1 & 417 & 7.0 & 5,120 & 2,000 & 472 & 204 \\
\hline DTX2 & $11 / 20 / 2007$ & 1145 & 3 & 11.7 & .4 & 6.7 & 5,330 & 11.5 & 403 & 7.2 & 5,280 & 2,200 & 501 & 224 \\
\hline DTX2 & $3 / 25 / 2008$ & 1245 & 20 & 11.53 & .4 & 7.0 & 5,550 & 10.5 & 432 & 7.1 & 5,470 & 2,200 & 494 & 228 \\
\hline DTX2 & $6 / 24 / 2008$ & 1415 & -- & 11.61 & .3 & 6.8 & 5,770 & 12.4 & ${ }^{1} 432$ & 7.2 & 5,500 & 2,200 & 490 & 232 \\
\hline DTX2 & $9 / 17 / 2008$ & 1200 & 28 & 8.86 & .3 & 6.8 & 5,890 & 12.9 & ${ }^{1} 420$ & 7.1 & 5,840 & 2,300 & 504 & 250 \\
\hline DTX2 & $11 / 18 / 2008$ & 1200 & 25.5 & 9.52 & .3 & 6.9 & 5,760 & 13.3 & ${ }^{1} 447$ & 7.1 & 5,750 & 2,300 & 495 & 250 \\
\hline DTX5 & $11 / 21 / 2008$ & 1015 & 13 & 10.85 & .6 & 6.9 & 3,210 & 11.8 & ${ }^{1} 309$ & 7.1 & 3,150 & 2,000 & 625 & 102 \\
\hline DTX6 & $11 / 21 / 2008$ & 1215 & 10 & 21.57 & .8 & 7.0 & 3,710 & 12.6 & ${ }^{1} 318$ & 7.2 & 3,720 & 2,100 & 442 & 240 \\
\hline DTX8A & 6/20/2007 & 0945 & 24 & 9.45 & .3 & 7.4 & 1,880 & 14.5 & 212 & 7.7 & 1,880 & 480 & 141 & 30.3 \\
\hline DTX8A & $6 / 24 / 2008$ & 1100 & 28 & 10.02 & .5 & 7.5 & 1,970 & 14.2 & ${ }^{1} 220$ & 7.6 & 1,880 & 540 & 156 & 34.7 \\
\hline DTX10A & 6/19/2007 & 1330 & 38 & 13.55 & .2 & 7.1 & 3,210 & 15.7 & 226 & 7.2 & 3,210 & 1,800 & 442 & 163 \\
\hline DTX10A & $6 / 23 / 2008$ & 1200 & 36 & 14.24 & .5 & 7.0 & 3,350 & 15.7 & ${ }^{1} 225$ & 7.2 & 3,150 & 1,800 & 450 & 168 \\
\hline D3 & 9/18/2008 & 1515 & 29.5 & 39.71 & 4.1 & 6.7 & 2,430 & 18.3 & ${ }^{1} 120$ & 7.2 & 2,410 & 1,500 & 421 & 107 \\
\hline D4 & 9/17/2008 & 1400 & 32.5 & 25.96 & 4.7 & 6.4 & 1,030 & 15.9 & ${ }^{1} 118$ & 6.9 & 1,210 & 540 & 158 & 35.2 \\
\hline D5 & $11 / 18 / 2007$ & 1030 & 14.5 & 17.13 & 1.9 & 7.0 & 4,300 & 13.4 & 229 & 7.5 & 4,130 & 2,500 & 490 & 304 \\
\hline D6 & 3/19/2007 & 1100 & -- & 8.01 & .5 & 6.8 & 17,300 & 11.3 & 599 & 7.2 & E17,600 & 11,000 & 436 & 2,460 \\
\hline D6 & $6 / 21 / 2007$ & 0945 & 29 & 8.24 & .4 & 7.0 & 17,800 & 13.5 & 636 & 7.2 & E17,600 & 11,000 & 424 & 2,350 \\
\hline D6 & 9/5/2007 & 1000 & 22 & 7.95 & .6 & 6.8 & 17,700 & 14.4 & 639 & 7.2 & E17,700 & 11,000 & 436 & 2,430 \\
\hline D6 & 11/19/2007 & 0945 & 18.5 & 8.94 & .5 & 6.9 & 17,900 & 13.2 & 594 & 7.3 & E17,300 & 11,000 & 458 & 2,450 \\
\hline D6 & 3/26/2008 & 1045 & 14 & 9.45 & .4 & 7.1 & 17,800 & 11.7 & 650 & 7.3 & E17,500 & 11,000 & 453 & 2,450 \\
\hline D6 & 6/23/2008 & 1545 & 33 & 9.6 & .4 & 6.9 & 17,500 & 13.5 & ${ }^{1} 652$ & 7.2 & E17,400 & 10,000 & 438 & 2,270 \\
\hline D6 & $9 / 18 / 2008$ & 1045 & 27.5 & 9.08 & .4 & 6.9 & 17,600 & 12.8 & ${ }^{1} 629$ & 7.3 & $\mathrm{E} 17,600$ & 10,000 & 437 & 2,160 \\
\hline D6 & $11 / 19 / 2008$ & 1100 & 20.5 & 9.44 & $<.5$ & 6.9 & 17,000 & 12.6 & ${ }^{1} 665$ & 7.2 & E17,500 & 11,000 & 443 & 2,490 \\
\hline
\end{tabular}


Table 10. Water-quality data for groundwater samples collected at U.S. Geological Survey monitoring wells near Deer Trail, Colorado, 2007 and $2008 .--C o n t i n u e d$

$\left[{ }^{\circ} \mathrm{C}\right.$, degrees Celsius; $\mathrm{mg} / \mathrm{L}$, milligrams per liter; $\mu \mathrm{S} / \mathrm{cm}$, microsiemens per centimeter at 25 degrees Celsius; $\mathrm{CaCO}_{3}$, calcium carbonate; $\mathrm{SiO}_{2}$, iliicon dioxide; $\mathrm{N}$, nitrogen; $\mu \mathrm{g} / \mathrm{L}$ micrograms per liter; $\mathrm{E}$, value estimated by laboratory; --, no data available; $\mathrm{n}$, value is less than the minimum reporting level; <, less than: $\mathrm{M}$, presence verified at very small concentration that could not be quantified]

\begin{tabular}{|c|c|c|c|c|c|c|c|c|c|c|c|c|c|c|}
\hline Well name & $\begin{array}{c}\text { Sample } \\
\text { date }\end{array}$ & $\begin{array}{c}\text { Sample } \\
\text { time } \\
(\mathrm{hhmm})\end{array}$ & $\begin{array}{c}\text { Air } \\
\text { temperature } \\
\left({ }^{\circ} \mathrm{C}\right) \\
\end{array}$ & 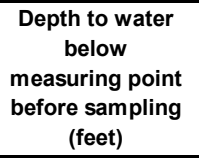 & $\begin{array}{l}\text { Oxygen, } \\
\text { dissolved } \\
\text { (mg/L) }\end{array}$ & $\begin{array}{c}\mathrm{pH} \text {, field } \\
\text { (standard } \\
\text { units) }\end{array}$ & $\begin{array}{c}\text { Specific } \\
\text { conductance, } \\
\text { field }(\mu \mathrm{S} / \mathrm{cm})\end{array}$ & $\begin{array}{c}\text { Water } \\
\text { temperature } \\
\left({ }^{\circ} \mathrm{C}\right)\end{array}$ & $\begin{array}{l}\text { Acid neutralizing } \\
\text { capacity, titration, } \\
\text { field }(\mathrm{mg} / \mathrm{L} \text { as } \\
\left.\mathrm{CaCO}_{3}\right)\end{array}$ & $\begin{array}{c}\mathrm{pH}, \\
\text { laboratory } \\
\text { (standard } \\
\text { units) } \\
\end{array}$ & $\begin{array}{c}\text { Specific } \\
\text { conductance, } \\
\text { laboratory } \\
(\mu \mathrm{S} / \mathrm{cm}) \\
\end{array}$ & $\begin{array}{c}\text { Hardness, } \\
\text { total }(\mathrm{mg} / \mathrm{L} \\
\left.\text { as } \mathrm{CaCO}_{3}\right)\end{array}$ & $\begin{array}{l}\text { Calcium, } \\
\text { dissolved } \\
\text { (mg/L) }\end{array}$ & $\begin{array}{c}\text { Magnesium, } \\
\text { dissolved } \\
\text { (mg/L) }\end{array}$ \\
\hline$\overline{\mathrm{D} 6 \mathrm{~A}}$ & $11 / 19 / 2007$ & 1230 & 29 & 8.82 & 0.7 & 6.9 & 17,600 & 12.3 & 599 & 7.3 & E17,400 & 11,000 & 439 & 2,400 \\
\hline D6A & 9/18/2008 & 1300 & 29 & 9.18 & .2 & 7.0 & 17,500 & 11.9 & ${ }^{1} 655$ & 7.3 & E17,400 & 10,000 & 437 & 2,150 \\
\hline D7 & 9/23/2008 & 1245 & 23 & 9.25 & 3.8 & 7.2 & 2,530 & 14.1 & ${ }^{1} 194$ & 7.6 & 2,380 & 1,600 & 418 & 133 \\
\hline D8 & 9/25/2008 & 1520 & 29 & 10.31 & .3 & 6.8 & 4,470 & 13.8 & ${ }^{1} 352$ & 7.3 & 4,390 & 2,400 & 555 & 242 \\
\hline D10 & $11 / 18 / 2007$ & 1300 & 24 & 9.53 & 2.6 & 6.9 & 4,570 & 13.8 & 309 & 7.5 & 4,390 & 2,700 & 472 & 361 \\
\hline D13 & 9/29/2008 & 1520 & 25 & 8.08 & 1.1 & 7.1 & 1,080 & 14.8 & ${ }^{1} 248$ & 7.6 & 1,030 & 500 & 138 & 37.3 \\
\hline D14 & 9/26/2008 & 1325 & 30.5 & 12.01 & .6 & 7.0 & 864 & 12.5 & ${ }^{1} 214$ & 7.5 & 802 & 390 & 121 & 21.4 \\
\hline D15 & 9/25/2008 & 1245 & 27 & 8.48 & .7 & 6.5 & 4,500 & 13.4 & ${ }^{1} 548$ & 7.0 & 4,210 & 2,300 & 481 & 266 \\
\hline D16 & 9/26/2008 & 1100 & 29 & 9.95 & .2 & 6.8 & 4,220 & 13.2 & ${ }^{1} 412$ & 7.2 & 4,080 & 2,200 & 541 & 214 \\
\hline D17 & $3 / 19 / 2007$ & 1440 & -- & 12.75 & .4 & 7.4 & 490 & 11.4 & 190 & 7.8 & 484 & 220 & 58.8 & 18.8 \\
\hline D17 & 6/19/2007 & 0930 & 21 & 11.92 & .7 & 7.5 & 490 & 12.3 & 200 & 7.7 & 483 & 220 & 57.1 & 17.7 \\
\hline D17 & 9/5/2007 & 1400 & 32 & 12.99 & .6 & 7.5 & 500 & 14.4 & 190 & 7.7 & 490 & 230 & 60.4 & 18.2 \\
\hline D17 & $11 / 20 / 2007$ & 1430 & 5 & 13.27 & .3 & 7.6 & 491 & 13.4 & ${ }^{1} 188$ & 7.8 & 490 & 220 & 59 & 18.4 \\
\hline D17 & $3 / 25 / 2008$ & 1530 & 21 & 13.1 & .6 & 7.5 & 477 & 11.7 & 202 & 7.9 & 486 & 230 & 60.2 & 19.1 \\
\hline D17 & $6 / 25 / 2008$ & 1000 & 34 & 13.06 & .3 & 7.4 & 490 & 12.4 & ${ }^{1} 199$ & 7.8 & 477 & 230 & 61.6 & 18.9 \\
\hline D17 & 9/19/2008 & 0930 & 20 & 13.09 & .3 & 7.5 & 479 & 13.5 & ${ }^{1} 184$ & 7.8 & 480 & 230 & 60.7 & 18.0 \\
\hline D17 & $11 / 18 / 2008$ & 1430 & 26.5 & 13.12 & .4 & 7.6 & 480 & 14.1 & ${ }^{\prime} 203$ & 7.8 & 475 & 230 & 60.6 & 18.5 \\
\hline D19 & 9/19/2008 & 1115 & 23 & 22.7 & 6.5 & 7.3 & 361 & 14.8 & ${ }^{1} 130$ & 7.6 & 354 & 170 & 59.1 & 4.90 \\
\hline D20 & 9/29/2008 & 1240 & 22.5 & 10.9 & .8 & 7.1 & 3,070 & 15.3 & 1230 & 7.5 & 3,030 & 1,800 & 467 & 154 \\
\hline D21 & 9/29/2008 & 1030 & 15.5 & 11.69 & .9 & 7.0 & 1,190 & 13.5 & ${ }^{1} 508$ & 7.0 & 1,900 & 660 & 200 & 39.1 \\
\hline D22 & 9/24/2008 & 1225 & -- & 18.32 & .4 & 6.9 & 10,500 & 17.6 & ${ }^{1} 586$ & 7.3 & E10,600 & 5,200 & 399 & 1,020 \\
\hline D23 & 9/25/2008 & 1015 & 23 & 6.91 & .9 & 6.9 & 5,150 & 13.8 & ${ }^{1} 470$ & 7.3 & 4,890 & 2,200 & 560 & 205 \\
\hline D25 & $3 / 20 / 2007$ & 1445 & 23 & 10.27 & .8 & 7.0 & 4,600 & 12 & 437 & 7.2 & 4,530 & 2,600 & 669 & 218 \\
\hline D25 & 6/21/2007 & 1430 & 39 & 10.67 & .7 & 7.0 & 4,600 & 15.5 & 473 & 7.3 & 4,580 & 2,600 & 664 & 224 \\
\hline D25 & 9/5/2007 & 1645 & 34 & 11.81 & .8 & 6.8 & 4,800 & 14.3 & 475 & 7.2 & 4,590 & 2,600 & 665 & 226 \\
\hline D25 & $11 / 20 / 2007$ & 1600 & 4 & 12.21 & .6 & 6.9 & 4,350 & 11.5 & ${ }^{1} 347$ & 7.3 & 4,450 & 2,500 & 688 & 184 \\
\hline D25 & $3 / 26 / 2008$ & 1350 & 22 & 12.02 & .5 & 7.0 & 4,410 & 12.6 & 372 & 7.3 & 4,490 & 2,600 & 728 & 179 \\
\hline D25 & $6 / 25 / 2008$ & 1215 & 34 & 12.3 & .7 & 6.8 & 4,580 & 15.1 & ${ }^{1} 377$ & 7.3 & 4,390 & 2,700 & 748 & 196 \\
\hline D25 & 9/16/2008 & 1315 & 28.5 & 12.51 & .6 & 6.9 & 4,460 & 14.9 & ${ }^{1} 395$ & 7.3 & 4,460 & 2,500 & 663 & 211 \\
\hline D25 & $11 / 19 / 2008$ & 1515 & 20 & 12.59 & $<.8$ & 7.0 & 4,510 & 13.6 & ${ }^{1} 366$ & 7.2 & 4,420 & 2,600 & 733 & 188 \\
\hline $\mathrm{D} 25 \mathrm{~A}$ & $3 / 26 / 2008$ & 1530 & 26 & 11.96 & .9 & 7.0 & 4,420 & 12.7 & 336 & 7.3 & 4,440 & 2,500 & 724 & 160 \\
\hline D26 & 9/16/2008 & 1040 & 27 & 32.71 & 8.2 & 7.3 & 707 & 13.1 & ${ }^{1} 251$ & 7.6 & 708 & 330 & 101 & 19.3 \\
\hline D27 & 9/23/2008 & 1015 & 20 & 10.51 & .7 & 7.2 & 3,040 & 13.5 & ${ }^{1} 245$ & 7.6 & 2,970 & 1,900 & 555 & 129 \\
\hline D28 & 9/23/2008 & 1445 & 27.5 & 12.93 & 1.0 & 6.8 & 3,040 & 12.8 & ${ }^{1} 256$ & 7.3 & 2,900 & 1,800 & 460 & 167 \\
\hline D31 & $11 / 19 / 2008$ & 1330 & -- & 6.06 & $<.5$ & 7.2 & 7,800 & 12.5 & ${ }^{1} 533$ & 7.3 & 7,710 & 4,800 & 465 & 871 \\
\hline D32 & $12 / 20 / 2007$ & 1120 & 13 & 29.06 & 2.4 & 6.9 & 3,500 & 12.8 & 285 & 7.4 & 3,640 & 2,500 & 551 & 265 \\
\hline D33 & $11 / 18 / 2007$ & 1500 & 24 & 12.51 & 4.3 & 7.0 & 4,560 & 13.8 & 230 & 7.6 & 4,380 & 2,800 & 526 & 352 \\
\hline
\end{tabular}


$\left[{ }^{\circ} \mathrm{C}\right.$, degrees Celsius; $\mathrm{mg} / \mathrm{L}$, milligrams per liter; $\mu \mathrm{S} / \mathrm{cm}$, microsiemens per centimeter at 25 degrees Celsius; $\mathrm{CaCO}_{3}$, calcium carbonate; $\mathrm{SiO}_{2}$, silicon dioxide; $\mathrm{N}$, nitrogen; $\mu \mathrm{g} / \mathrm{L}$ micrograms per liter; $\mathrm{E}$, value estimated by laboratory; - , no data available; $\mathrm{n}$, value is less than the

\begin{tabular}{|c|c|c|c|c|c|c|c|c|c|c|c|c|c|c|c|}
\hline Well name & $\begin{array}{c}\text { Sample } \\
\text { date }\end{array}$ & $\begin{array}{c}\text { Sample } \\
\text { time } \\
(\mathrm{hhmm})\end{array}$ & $\begin{array}{c}\text { Potassium, } \\
\text { dissolved } \\
(\mathrm{mg} / \mathrm{L})\end{array}$ & $\begin{array}{l}\text { Sodium } \\
\text { adsorption } \\
\text { ratio }\end{array}$ & $\begin{array}{l}\text { Sodium, } \\
\text { dissolved } \\
\text { (mg/L) }\end{array}$ & $\begin{array}{c}\text { Acid neutralizing } \\
\text { capacity, titration } \\
\text { to } \mathrm{pH} 4.5, \\
\text { laboratory }(\mathrm{mg} / \mathrm{L} \\
\left.\text { as } \mathrm{CaCO}_{3}\right)\end{array}$ & $\begin{array}{l}\text { Bromide, } \\
\text { dissolved } \\
(\mathrm{mg} / \mathrm{L})\end{array}$ & $\begin{array}{l}\text { Chloride, } \\
\text { dissolved } \\
(\mathrm{mg} / \mathrm{L})\end{array}$ & $\begin{array}{c}\text { Fluoride, } \\
\text { dissolved } \\
\text { (mg/L) }\end{array}$ & $\begin{array}{c}\text { Silica, } \\
\text { dissolved } \\
\text { (mg/L as } \\
\left.\mathrm{SiO}_{2}\right)\end{array}$ & $\begin{array}{l}\text { Sulfate, } \\
\text { dissolved } \\
(\mathrm{mg} / \mathrm{L})\end{array}$ & $\begin{array}{c}\text { Nitrogen, } \\
\text { ammonia } \\
\text { plus organic, } \\
\text { dissolved } \\
\text { (mg/L as N) }\end{array}$ & $\begin{array}{c}\text { Nitrogen, } \\
\text { ammonia } \\
\text { plus organic, } \\
\text { total } \\
\text { (mg/L as } \mathrm{N})\end{array}$ & $\begin{array}{c}\text { Nitrogen, } \\
\text { ammonia, } \\
\text { dissolved } \\
\text { (mg/L as } \mathrm{N})\end{array}$ & $\begin{array}{c}\text { Nitrite } \\
\text { plus nitrate, } \\
\text { dissolved } \\
\text { (mg/L as } \mathrm{N})\end{array}$ \\
\hline$\overline{\text { DTX1 }}$ & $3 / 20 / 2007$ & 1145 & 3.36 & 3.3 & 337 & 301 & 0.77 & 51.4 & 0.69 & 35.0 & 2,300 & $<1.0$ & 0.23 & $<0.080$ & 3.13 \\
\hline DTX1 & $6 / 25 / 2007$ & 1340 & 3.41 & 3.3 & 332 & 296 & .79 & 50.9 & .67 & 33.3 & 2,280 & .24 & .23 & .05 & 2.84 \\
\hline DTX1 & 9/7/2007 & 0915 & 3.65 & 3.3 & 331 & 296 & .76 & 49.5 & .60 & 31.5 & 2,290 & .22 & .17 & .042 & 2.67 \\
\hline DTX1 & $11 / 20 / 2007$ & 0915 & 3.86 & 3.5 & 355 & 297 & .77 & 52.1 & .65 & 34.4 & 2,370 & .21 & .22 & E,n .035 & 2.49 \\
\hline DTX1 & $3 / 25 / 2008$ & 1000 & 3.67 & 3.2 & 324 & 292 & .79 & 53.6 & .66 & 32.7 & 2,320 & .23 & .23 & E,n .030 & 2.73 \\
\hline DTX1 & $6 / 25 / 2008$ & 1415 & 3.82 & 3.3 & 341 & 292 & .78 & 53.0 & .61 & 32.4 & 2,300 & .22 & .24 & E,n .028 & 2.97 \\
\hline DTX1 & 9/17/2008 & 1000 & 3.81 & 3.4 & 350 & 290 & .8 & 52.4 & .67 & 31.4 & 2,300 & .24 & .24 & .041 & 3.08 \\
\hline DTX1 & $11 / 18 / 2008$ & 1015 & 3.9 & 3.4 & 350 & 291 & .8 & 54.7 & .66 & 34.0 & 2,340 & .21 & .24 & $<.200$ & 3.08 \\
\hline DTX2 & 3/20/2007 & 0930 & 9.88 & 5.9 & 628 & 435 & 1.32 & 110 & .58 & 15.9 & 2,930 & 1.1 & 1.2 & .920 & E,n .02 \\
\hline DTX2 & $6 / 25 / 2007$ & 1045 & 9.8 & 6.0 & 633 & 429 & 1.30 & 110 & .61 & 15.7 & 2,910 & 1.2 & 1.3 & .942 & $<.04$ \\
\hline DTX2 & 9/7/2007 & 1125 & 9.66 & 5.5 & 563 & 431 & 1.10 & 94.3 & .61 & 14.3 & 2,750 & 1.2 & 1.2 & .974 & $<.04$ \\
\hline DTX2 & $11 / 20 / 2007$ & 1145 & 10.4 & 5.8 & 618 & 438 & 1.18 & 108 & .62 & 16.4 & 2,850 & 1.3 & 1.2 & 1.03 & $<.04$ \\
\hline DTX2 & $3 / 25 / 2008$ & 1245 & 10.4 & 6.1 & 658 & 436 & 1.21 & 116 & .61 & 15.2 & 2,940 & 1.2 & 1.3 & .955 & $<.04$ \\
\hline DTX2 & $6 / 24 / 2008$ & 1415 & 10.8 & 6.4 & 688 & 432 & 1.23 & 116 & .59 & 14.8 & 3,010 & 1.4 & 1.3 & 1.04 & $<.04$ \\
\hline DTX2 & 9/17/2008 & 1200 & 12.1 & 6.8 & 744 & 428 & 1.39 & 121 & .66 & 14.8 & 3,200 & 1.5 & 1.5 & 1.25 & $<.04$ \\
\hline DTX2 & $11 / 18 / 2008$ & 1200 & 12.2 & 6.8 & 749 & 442 & 1.34 & 121 & .64 & 16.6 & 3,140 & 1.5 & 1.6 & 1.27 & $<.40$ \\
\hline DTX5 & $11 / 21 / 2008$ & 1015 & 4.86 & 1.3 & 138 & 304 & .33 & 17.0 & .35 & 11.5 & 1,810 & .19 & .17 & .064 & $<.04$ \\
\hline DTX6 & $11 / 21 / 2008$ & 1215 & 12.8 & 2.4 & 250 & 316 & .11 & 13.4 & .54 & 11.8 & 2,190 & .14 & .10 & .047 & 2.03 \\
\hline DTX8A & 6/20/2007 & 0945 & 6.08 & 4.8 & 242 & 222 & .28 & 27.0 & .43 & 12.8 & 761 & 1.4 & 1.5 & 1.45 & $<.04$ \\
\hline DTX8A & 6/24/2008 & 1100 & 6.49 & 4.3 & 228 & 224 & .28 & 27.1 & .35 & 13.4 & 775 & 1.5 & 1.5 & 1.41 & $<.04$ \\
\hline DTX10A & 6/19/2007 & 1330 & 8.87 & 1.7 & 168 & 225 & .24 & 18.4 & 1.03 & 16.3 & 1,890 & 1.3 & 1.3 & 1.32 & $<.04$ \\
\hline DTX10A & $6 / 23 / 2008$ & 1200 & 9.29 & 1.6 & 160 & 224 & .25 & 18.3 & .94 & 15.3 & 1,920 & 1.4 & 1.4 & 1.3 & $<.04$ \\
\hline D3 & 9/18/2008 & 1515 & 4.96 & .7 & 61 & 126 & .3 & 27.1 & 1.17 & 28.3 & 1,370 & E,n .11 & E,n.12 & E,n. .038 & 3.21 \\
\hline D4 & 9/17/2008 & 1400 & 3.02 & .5 & 27 & 119 & .06 & 4.34 & 1.24 & 37.7 & 461 & $<.14$ & $<.14$ & $<.040$ & .81 \\
\hline D5 & $11 / 18 / 2007$ & 1030 & 5.75 & 2.2 & 246 & 241 & .37 & 27.9 & .57 & 19.0 & 2,670 & .22 & .21 & $<.040$ & 8.75 \\
\hline D6 & 3/19/2007 & 1100 & 14.7 & 9.5 & 2,300 & 649 & 4.60 & 387 & 1.20 & 21.6 & 13,500 & 1.5 & 1.7 & .123 & 40.6 \\
\hline D6 & $6 / 21 / 2007$ & 0945 & 14.6 & 9.8 & 2,330 & 648 & 4.49 & 387 & 1.23 & 20.8 & 13,400 & 1.6 & 1.6 & .076 & 41.6 \\
\hline D6 & 9/5/2007 & 1000 & 13.5 & 9.4 & 2,280 & 650 & 4.42 & 390 & 1.13 & 20.9 & 13,700 & 1.6 & 1.7 & .079 & 42.3 \\
\hline D6 & $11 / 19 / 2007$ & 0945 & 14.5 & 9.7 & 2,360 & 650 & 4.45 & 385 & 1.16 & 21.8 & 14,000 & 1.6 & 1.6 & .068 & 41.5 \\
\hline D6 & $3 / 26 / 2008$ & 1045 & 15.1 & 9.4 & 2,300 & 650 & 4.37 & 382 & 1.28 & 21.4 & 13,800 & 1.5 & 1.6 & .086 & 38.8 \\
\hline D6 & $6 / 23 / 2008$ & 1545 & 14.2 & 9.2 & 2,160 & 654 & 4.26 & 381 & 1.18 & 19.4 & 13,800 & 1.7 & 1.5 & .080 & 39.4 \\
\hline D6 & 9/18/2008 & 1045 & 14.8 & 11 & 2,410 & 648 & 4.30 & 372 & 1.24 & 18.1 & 13,900 & 1.5 & 1.7 & .072 & 41.4 \\
\hline D6 & $11 / 19 / 2008$ & 1100 & 14.8 & 9.6 & 2,350 & 650 & 4.27 & 368 & 1.22 & 20.8 & 13,800 & 1.6 & 1.6 & $<1.00$ & 40.4 \\
\hline
\end{tabular}


Table 10. Water-quality data for groundwater samples collected at U.S. Geological Survey monitoring wells near Deer Trail, Colorado, 2007 and 2008. --Continued

[ ${ }^{\circ} \mathrm{C}$, degrees Celsius; $\mathrm{mg} / \mathrm{L}$, milligrams per liter; $\mu \mathrm{S} / \mathrm{cm}$, microsiemens per centimeter at 25 degrees $\mathrm{Celsius;} \mathrm{CaCO}_{3}$, calcium carbonate; $\mathrm{SiO}_{2}$, silicon dioxide; $\mathrm{N}$, nitrogen; $\mu \mathrm{gg} / \mathrm{L}$ micrograms per liter; $\mathrm{E}$, value estimated by laboratory; --, no data avaliable; $\mathrm{n}$, value is less than the minimum reporting level; <, less than; $\mathrm{M}$, presence verified at very small concentration that could not be quantified]

\begin{tabular}{|c|c|c|c|c|c|c|c|c|c|c|c|c|c|c|c|}
\hline Well name & $\begin{array}{c}\text { Sample } \\
\text { date }\end{array}$ & $\begin{array}{c}\text { Sample } \\
\text { time } \\
(\mathrm{hhmm})\end{array}$ & $\begin{array}{l}\text { Potassium, } \\
\text { dissolved } \\
(\mathrm{mg} / \mathrm{L})\end{array}$ & $\begin{array}{c}\text { Sodium } \\
\text { adsorption } \\
\text { ratio }\end{array}$ & $\begin{array}{c}\text { Sodium, } \\
\text { dissolved } \\
\text { (mg/L) }\end{array}$ & $\begin{array}{c}\text { Acid neutralizing } \\
\text { capacity, titration } \\
\text { to } \mathrm{pH} 4.5, \\
\text { laboratory }(\mathrm{mg} / \mathrm{L} \\
\left.\text { as } \mathrm{CaCO}_{3}\right)\end{array}$ & $\begin{array}{c}\text { Bromide, } \\
\text { dissolved } \\
\text { (mg/L) }\end{array}$ & $\begin{array}{l}\text { Chloride, } \\
\text { dissolved } \\
(\mathrm{mg} / \mathrm{L})\end{array}$ & $\begin{array}{l}\text { Fluoride, } \\
\text { dissolved } \\
(\mathrm{mg} / \mathrm{L})\end{array}$ & $\begin{array}{c}\text { Silica, } \\
\text { dissolved } \\
(\mathrm{mg} / \mathrm{L} \text { as } \\
\left.\mathrm{SiO}_{2}\right)\end{array}$ & $\begin{array}{c}\text { Sulfate, } \\
\text { dissolved } \\
(\mathrm{mg} / \mathrm{L})\end{array}$ & $\begin{array}{c}\text { Nitrogen, } \\
\text { ammonia } \\
\text { plus organic, } \\
\text { dissolved } \\
\text { (mg/L as N) } \\
\end{array}$ & $\begin{array}{c}\text { Nitrogen, } \\
\text { ammonia } \\
\text { plus organic, } \\
\text { total } \\
\text { (mg/L as } \mathrm{N} \text { ) } \\
\end{array}$ & $\begin{array}{c}\text { Nitrogen, } \\
\text { ammonia, } \\
\text { dissolved } \\
\text { (mg/L as N) } \\
\end{array}$ & $\begin{array}{c}\text { Nitrite } \\
\text { plus nitrate, } \\
\text { dissolved } \\
(\mathrm{mg} / \mathrm{L} \text { as } \mathrm{N}) \\
\end{array}$ \\
\hline$\overline{\mathrm{D} 6 \mathrm{~A}}$ & $11 / 19 / 2007$ & 1230 & 14.4 & 9.4 & 2,270 & 651 & 4.21 & 385 & 1.14 & 21.5 & 13,900 & 1.6 & 1.6 & 0.071 & 37.3 \\
\hline D6A & 9/18/2008 & 1300 & 14.8 & 10 & 2,390 & 646 & 4.26 & 368 & 1.26 & 18 & 13,800 & 1.6 & 1.7 & . 077 & 43.2 \\
\hline D7 & 9/23/2008 & 1245 & 3.69 & .6 & 58.9 & 200 & .25 & 11.7 & .78 & 29.1 & 1,260 & .32 & .31 & .041 & 29.9 \\
\hline D8 & $9 / 25 / 2008$ & 1520 & 6.36 & 3.2 & 364 & 348 & .86 & 40.5 & 1.06 & 27.2 & 2,630 & .63 & .55 & .269 & $<.04$ \\
\hline D10 & $11 / 18 / 2007$ & 1300 & 16.6 & 2.2 & 261 & 350 & .17 & 11.6 & .74 & 20.3 & 2,660 & .64 & .61 & E,n .022 & 10.8 \\
\hline D13 & 9/29/2008 & 1520 & 2.64 & 1.0 & 51.3 & 246 & .10 & 2.55 & 1.40 & 14.2 & 315 & E,n .12 & E,n .13 & .049 & $<.04$ \\
\hline D14 & 9/26/2008 & 1325 & 2.3 & .6 & 28.7 & 214 & .16 & 5.96 & 1.07 & 22.6 & 182 & .22 & E,n .1 & $<.040$ & 7.91 \\
\hline D15 & 9/25/2008 & 1245 & 5.72 & 3.1 & 343 & 547 & .62 & 15.3 & 1.80 & 17.1 & 2,360 & 1.3 & 1.2 & 1.07 & $<.04$ \\
\hline D16 & 9/26/2008 & 1100 & 5.07 & 2.8 & 309 & 398 & .65 & 29.1 & 1.31 & 20.1 & 2,360 & .89 & .86 & .691 & $<.04$ \\
\hline D17 & $3 / 19 / 2007$ & 1440 & 1.62 & .5 & 17.3 & 203 & .05 & 2.21 & 1.34 & 17.9 & 52.1 & $<.10$ & .11 & $<.040$ & .83 \\
\hline D17 & 6/19/2007 & 0930 & 1.54 & .5 & 17.7 & 203 & .05 & 2.36 & 1.42 & 17.8 & 48.1 & E,n .08 & E,n .08 & E,n .029 & .90 \\
\hline D17 & 9/5/2007 & 1400 & 1.62 & .5 & 17.7 & 203 & .07 & 2.32 & 1.37 & 18.2 & 50.6 & E,n .06 & E,n .07 & $<.040$ & .83 \\
\hline D17 & $11 / 20 / 2007$ & 1430 & 1.81 & .5 & 18.5 & 203 & .06 & 2.46 & 1.36 & 18.6 & 49.9 & E,n .10 & $<.14$ & $<.040$ & .88 \\
\hline D17 & $3 / 25 / 2008$ & 1530 & 1.62 & .5 & 17.3 & 202 & .06 & 2.44 & 1.41 & 18.7 & 49.6 & E,n .07 & $<.14$ & $<.040$ & .85 \\
\hline D17 & $6 / 25 / 2008$ & 1000 & 1.76 & .5 & 18.3 & 202 & .06 & 2.37 & 1.36 & 17.6 & 49.6 & E,n .13 & $<.14$ & $<.040$ & .85 \\
\hline D17 & 9/19/2008 & 0930 & 1.7 & .5 & 17.2 & 201 & .07 & 2.33 & 1.44 & 18.4 & 47.9 & $<.14$ & E,n .11 & $<.040$ & .88 \\
\hline D17 & $11 / 18 / 2008$ & 1430 & 1.75 & .5 & 18.0 & 203 & .07 & 2.40 & 1.38 & 19.0 & 48.4 & .14 & E,n .07 & $<.040$ & .89 \\
\hline D19 & 9/19/2008 & 1115 & 0.48 & .2 & 7.03 & 131 & .07 & 4.12 & .20 & 16.8 & 20.5 & E,n .12 & E,n .12 & $<.040$ & 6.53 \\
\hline D20 & 9/29/2008 & 1240 & 6.24 & 1.5 & 146 & 236 & .25 & 6.15 & .93 & 30.3 & 1,810 & .37 & .38 & .224 & $<.04$ \\
\hline D21 & 9/29/2008 & 1030 & 5.90 & .7 & 40.3 & 497 & .10 & 3.30 & .92 & 24.6 & 467 & 3.3 & 3.9 & 2.98 & $<.04$ \\
\hline D22 & 9/24/2008 & 1225 & 13.8 & 8.4 & 1,390 & 579 & .85 & 72.3 & 1.31 & 9.05 & 7,500 & 1.3 & 1.2 & .818 & 5.24 \\
\hline D23 & 9/25/2008 & 1015 & 9.71 & 5.0 & 541 & 471 & .48 & 50.2 & 1.00 & 15.3 & 2,800 & 2.0 & 1.8 & .613 & .07 \\
\hline D25 & $3 / 20 / 2007$ & 1445 & 7.07 & 2.5 & 291 & 464 & 1.77 & 102 & 1.02 & 27.9 & 2,550 & .63 & .79 & .088 & 3.16 \\
\hline D25 & $6 / 21 / 2007$ & 1430 & 6.79 & 2.4 & 280 & 483 & 1.73 & 99.1 & 1.12 & 26.4 & 2,570 & .72 & .79 & .063 & 4.00 \\
\hline D25 & 9/5/2007 & 1645 & 7.21 & 2.4 & 283 & 506 & 1.73 & 98.5 & .99 & 27.2 & 2,560 & .74 & .75 & .062 & 4.54 \\
\hline D25 & $11 / 20 / 2007$ & 1600 & 8.16 & 2.5 & 289 & 383 & 1.84 & 131 & 1.04 & 25.7 & 2,590 & .61 & .50 & .072 & .61 \\
\hline D25 & $3 / 26 / 2008$ & 1350 & 7.52 & 2.3 & 269 & 370 & 1.96 & 127 & 1.05 & 23.9 & 2,560 & .54 & .52 & .066 & .50 \\
\hline D25 & $6 / 25 / 2008$ & 1215 & 8.42 & 2.3 & 276 & 387 & 1.90 & 120 & 1.01 & 24.5 & 2,570 & .62 & .59 & .073 & 1.44 \\
\hline D25 & 9/16/2008 & 1315 & 7.61 & 2.3 & 266 & 422 & 1.94 & 113 & 1.15 & 25.8 & 2,500 & .69 & .68 & .059 & 3.11 \\
\hline D25 & $11 / 19 / 2008$ & 1515 & 8.11 & 2.3 & 271 & 370 & 2.03 & 132 & 1.05 & 25.6 & 2,560 & .55 & .56 & .063 & .32 \\
\hline D25A & $3 / 26 / 2008$ & 1530 & 7.48 & 2.3 & 263 & 352 & 1.99 & 134 & 1.08 & 25.5 & 2,530 & .47 & .46 & .085 & $<.04$ \\
\hline D26 & 9/16/2008 & 1040 & 3.75 & .3 & 12.1 & 259 & .07 & 5.12 & .58 & 17.3 & 57 & .29 & .28 & $<.040$ & 13.6 \\
\hline D27 & 9/23/2008 & 1015 & 9.53 & .9 & 85.7 & 122 & .38 & 22.7 & .20 & 36.8 & 1,710 & .47 & .47 & .061 & 17.0 \\
\hline D28 & 9/23/2008 & 1445 & 7.49 & .9 & 91.0 & 247 & .45 & 33.5 & .89 & 20.7 & 1,580 & .27 & .33 & .040 & 18.7 \\
\hline D31 & $11 / 19 / 2008$ & 1330 & 5.45 & 4.5 & 713 & 530 & 1.07 & 115 & 1.41 & 14.9 & 5,160 & .55 & .57 & $<.400$ & $<.40$ \\
\hline D32 & $12 / 20 / 2007$ & 1120 & 2.0 & 1.0 & 120 & 335 & 0.47 & 32.5 & 0.82 & 26.4 & 2,150 & .17 & .16 & Е. 038 & 16.7 \\
\hline D33 & $11 / 18 / 2007$ & 1500 & 14.6 & 1.8 & 213 & 261 & 1.06 & 61.6 & .65 & 31.3 & 2,880 & .31 & .34 & E,n .023 & .99 \\
\hline
\end{tabular}


$\left[{ }^{\circ} \mathrm{C}\right.$, degrees Celsius; $\mathrm{mg} / \mathrm{L}$, milligrams per liter; $\mu \mathrm{S} / \mathrm{cm}$, microsiemens per centimeter at 25 degrees Celsius; $\mathrm{CaCO}_{3}$, calcium carbonate; $\mathrm{SiO}_{2}$, silicon dioxide; $\mathrm{N}$, nitrogen; $\mu \mathrm{g} / \mathrm{L}$ micrograms per liter; $\mathrm{E}$, value estimated by laboratory; -- , no data available; $\mathrm{n}$, value is less than the minimum reporting level; $<$, less than; $\mathrm{M}$, presence verified at very small concentration that could not be quantified

\begin{tabular}{|c|c|c|c|c|c|c|c|c|c|c|c|c|c|c|c|}
\hline Well name & $\begin{array}{c}\text { Sample } \\
\text { date }\end{array}$ & $\begin{array}{c}\text { Sample } \\
\text { time } \\
(\mathrm{hhmm})\end{array}$ & $\begin{array}{l}\text { Phosphorus, } \\
\text { dissolved } \\
\text { (mg/L) }\end{array}$ & $\begin{array}{c}\text { Phosphorus, } \\
\text { total } \\
\text { (mg/L) }\end{array}$ & $\begin{array}{c}\text { Solids, residue } \\
\text { on evaporation } \\
\text { at } 180^{\circ} \mathrm{C}, \\
\text { dissolved } \\
\text { (mg/L) }\end{array}$ & $\begin{array}{l}\text { Dissolved } \\
\text { solids, sum of } \\
\text { constituents } \\
\text { (mg/L) }\end{array}$ & $\begin{array}{c}\text { Aluminum, } \\
\text { dissolved } \\
(\mu \mathrm{g} / \mathrm{L})\end{array}$ & $\begin{array}{l}\text { Antimony, } \\
\text { dissolved } \\
(\mu \mathrm{g} / \mathrm{L})\end{array}$ & $\begin{array}{l}\text { Arsenic, } \\
\text { dissolved } \\
(\mu \mathrm{g} / \mathrm{L})\end{array}$ & $\begin{array}{c}\text { Barium, } \\
\text { dissolved } \\
(\mu \mathrm{g} / \mathrm{L})\end{array}$ & $\begin{array}{c}\text { Beryllium, } \\
\text { dissolved } \\
(\mu \mathrm{g} / \mathrm{L})\end{array}$ & $\begin{array}{c}\text { Boron, } \\
\text { dissolved } \\
(\mu \mathrm{g} / \mathrm{L})\end{array}$ & $\begin{array}{c}\text { Cadmium, } \\
\text { dissolved } \\
(\mu \mathrm{g} / \mathrm{L})\end{array}$ & $\begin{array}{c}\text { Chromium, } \\
\text { dissolved } \\
(\mu \mathrm{g} / \mathrm{L})\end{array}$ & $\begin{array}{c}\text { Cobalt, } \\
\text { dissolved } \\
(\mu \mathrm{g} / \mathrm{L})\end{array}$ \\
\hline DTX1 & $3 / 20 / 2007$ & 1145 & $<0.40$ & 0.08 & 4,040 & E3,580 & E,n 1.8 & 0.15 & 2.4 & 8 & $<0.12$ & 418 & 0.14 & E,n 0.17 & 0.16 \\
\hline DTX1 & $6 / 25 / 2007$ & 1340 & .06 & .07 & 3,900 & $\mathrm{E} 3,560$ & E,n 2.2 & E,n .06 & 1.5 & 8 & $<.12$ & 430 & .14 & $<.24$ & .10 \\
\hline DTX1 & 9/7/2007 & 0915 & .07 & .07 & 3,980 & $\mathrm{E} 3,530$ & $<3.2$ & E,n .11 & 1.6 & 9 & $<.12$ & 408 & .26 & E,n .16 & .34 \\
\hline DTX1 & $11 / 20 / 2007$ & 0915 & .07 & .07 & 4,000 & $\mathrm{E} 3,640$ & $<4.8$ & $<.42$ & 1.6 & 9 & $<.02$ & 457 & .24 & $<.36$ & .31 \\
\hline DTX1 & $3 / 25 / 2008$ & 1000 & .08 & .07 & 3,920 & $\mathrm{E} 3,580$ & $<3.2$ & $<.28$ & 1.6 & 8 & $<.02$ & 429 & .18 & $<.24$ & .31 \\
\hline DTX1 & $6 / 25 / 2008$ & 1415 & .07 & .07 & 3,980 & $\mathrm{E} 3,600$ & $<3.2$ & $<.28$ & 1.7 & 8 & $<.02$ & 385 & .16 & E,n .15 & .32 \\
\hline DTX1 & 9/17/2008 & 1000 & .06 & .07 & 3,950 & 3,590 & $<8.0$ & $<.70$ & 1.3 & 8 & $<.04$ & 379 & .23 & $<.60$ & .32 \\
\hline DTX1 & $11 / 18 / 2008$ & 1015 & .08 & .07 & 3,970 & $\mathrm{E} 3,660$ & $<12.0$ & .2 & 1.5 & 9 & $<.06$ & 403 & .20 & $<.36$ & .41 \\
\hline DTX2 & $3 / 20 / 2007$ & 0930 & $<.04$ & $<.04$ & 5,090 & $\mathrm{E} 4,680$ & $<4.8$ & .37 & .70 & 13 & $<.18$ & 261 & $<.12$ & $<.36$ & 4.6 \\
\hline DTX2 & $6 / 25 / 2007$ & 1045 & $<.04$ & E,n .02 & 5,080 & & E,n 2.5 & $<.18$ & .69 & 14 & $<.18$ & 274 & $<.12$ & $<.36$ & 4.7 \\
\hline DTX2 & 9/7/2007 & 1125 & $<.04$ & $<.04$ & 4,850 & $\mathrm{E} 4,370$ & $<4.8$ & E,n .12 & .75 & 14 & $<.18$ & 273 & $<.12$ & $<.36$ & 5.9 \\
\hline DTX2 & $11 / 20 / 2007$ & 1145 & $<.04$ & $<.04$ & 5,040 & $\mathrm{E} 4,590$ & $<8.0$ & $<.70$ & .94 & 15 & $<.04$ & 301 & $<.20$ & $<.60$ & 5.4 \\
\hline DTX2 & $3 / 25 / 2008$ & 1245 & E,n .03 & E,n .02 & 5,160 & $\mathrm{E} 4,730$ & $<4.8$ & E,n .23 & .84 & 14 & $<.02$ & 278 & E,n .06 & $<.36$ & 5.8 \\
\hline DTX2 & 6/24/2008 & 1415 & $<.04$ & E,n .02 & 5,360 & $\mathrm{E} 4,830$ & $<4.8$ & $<.42$ & .78 & 14 & $<.02$ & 252 & E,n .07 & .39 & 5.6 \\
\hline DTX2 & 9/17/2008 & 1200 & $<.04$ & $<.04$ & 5,530 & 5,110 & $<8.0$ & $<.70$ & .72 & 14 & $<.04$ & 267 & $<.20$ & $<.60$ & 4.9 \\
\hline DTX2 & $11 / 18 / 2008$ & 1200 & E,n .02 & $<.04$ & 5,530 & $\mathrm{E} 5,070$ & $<16.0$ & .21 & .94 & 14 & $<.08$ & 284 & $<.08$ & $<.48$ & 5.9 \\
\hline DTX5 & $11 / 21 / 2008$ & 1015 & $<.04$ & $<.04$ & 3,080 & $\mathrm{E} 2,900$ & $<8.0$ & .15 & .20 & 13 & $<.04$ & 481 & .06 & $<.24$ & .65 \\
\hline DTX6 & $11 / 21 / 2008$ & 1215 & $<.04$ & $<.04$ & 3,640 & $\mathrm{E} 3,360$ & $<8.0$ & .09 & .14 & 9 & $<.04$ & 356 & $<.04$ & $<.24$ & .26 \\
\hline DTX8A & 6/20/2007 & 0945 & $<.04$ & $<.04$ & 1,430 & $\mathrm{E} 1,350$ & 1.9 & E,n .05 & E,n .12 & 11 & $<.06$ & 249 & $<.04$ & .13 & .31 \\
\hline DTX8A & 6/24/2008 & 1100 & $<.04$ & $<.04$ & 1,420 & $\mathrm{E} 1,380$ & E,n 1.3 & $<.14$ & .12 & 11 & M & 258 & $<.04$ & .13 & .23 \\
\hline DTX10A & 6/19/2007 & 1330 & $<.04$ & $<.04$ & 3,020 & $\mathrm{E} 2,860$ & $<3.2$ & $<.12$ & $\mathrm{E}, \mathrm{n} .12$ & 12 & $<.12$ & 235 & $<.08$ & E,n .18 & .10 \\
\hline DTX10A & $6 / 23 / 2008$ & 1200 & $<.04$ & $<.04$ & 3,160 & 2,890 & $<3.2$ & $<.28$ & .15 & 12 & .02 & 219 & $<.08$ & .25 & .34 \\
\hline D3 & 9/18/2008 & 1515 & .04 & .07 & 2,280 & $\mathrm{E} 2,100$ & E2.8 & $<.42$ & .26 & 8 & .04 & 115 & E.09 & .98 & .65 \\
\hline D4 & 9/17/2008 & 1400 & .31 & .31 & 884 & E802 & E,n 1.2 & $<.14$ & 1.0 & 7 & $<.01$ & 52 & $<.04$ & .50 & .11 \\
\hline D5 & $11 / 18 / 2007$ & 1030 & $<.04$ & $<.04$ & 4,250 & E3,940 & $<4.8$ & $<.42$ & .38 & 10 & $<.02$ & 314 & $<.12$ & .49 & .17 \\
\hline D6 & 3/19/2007 & 1100 & E,n .02 & .04 & 22,800 & $\mathrm{E} 19,700$ & $<12.8$ & E,n .40 & 1.2 & 5 & $<.48$ & 792 & $<.32$ & $<.96$ & 6.8 \\
\hline D6 & $6 / 21 / 2007$ & 0945 & .04 & .04 & 21,400 & E19,600 & $<16.0$ & $<.60$ & 1.2 & 6 & $<.60$ & 809 & $<.40$ & $<1.2$ & 6.7 \\
\hline D6 & 9/5/2007 & 1000 & E,n .03 & .04 & 21,400 & E19,900 & $<16.0$ & $<1.50$ & E,n 1.8 & 6 & $<1.50$ & 848 & $<1.00$ & $<3.0$ & 7.9 \\
\hline D6 & $11 / 19 / 2007$ & 0945 & E,n .04 & E,n .04 & 22,500 & 20,200 & $<12.8$ & $<1.12$ & 1.2 & 6 & $<.06$ & 855 & $<.32$ & $<.96$ & 7.1 \\
\hline D6 & $3 / 26 / 2008$ & 1045 & .04 & E,n .03 & 22,500 & 20,100 & $<12.8$ & $<1.12$ & 1.5 & 6 & $<.06$ & 871 & $<.32$ & $<.96$ & 7.4 \\
\hline D6 & $6 / 23 / 2008$ & 1545 & .04 & E,n .04 & 22,600 & E19,700 & $<11.2$ & $<.98$ & 1.6 & 6 & $<.06$ & 760 & E,n .14 & $<.84$ & 8.0 \\
\hline D6 & $9 / 18 / 2008$ & 1045 & E,n .03 & E,n .03 & 22,700 & 19,900 & $<16.0$ & $<1.40$ & 1.2 & 5 & $<.08$ & 708 & $<.40$ & $<1.2$ & 7.4 \\
\hline D6 & $11 / 19 / 2008$ & 1100 & E,n .04 & E,n .04 & 22,000 & E20,100 & $<40.0$ & E,n .40 & 1.3 & 5 & $<.20$ & 707 & $<.20$ & $<1.2$ & 7.2 \\
\hline
\end{tabular}


Table 10. Water-quality data for groundwater samples collected at U.S. Geological Survey monitoring wells near Deer Trail, Colorado, 2007 and $2008 .--C o n t i n u e d$

$\left[{ }^{\circ} \mathrm{C}\right.$, degrees Celsius; $\mathrm{mg} / \mathrm{L}$, milligrams per liter; $\mu \mathrm{S} / \mathrm{cm}$, microsiemens per centimeter at 25 degrees Celsius; $\mathrm{CaCO}_{3}$, calcium carbonate; $\mathrm{SiO}_{2}$, silicon dioxide; $\mathrm{N}$, nitrogen; $\mu \mathrm{g} / \mathrm{L}$ micrograms per liter; $\mathrm{E}$, value estimated by laboratory; --, no data available; $\mathrm{n}$, value is less than the minimum reporting level; $<$, less than; $\mathrm{M}$, presence verified at very small concentration that could not be quantified

\begin{tabular}{|c|c|c|c|c|c|c|c|c|c|c|c|c|c|c|c|}
\hline Well name & $\begin{array}{c}\text { Sample } \\
\text { date }\end{array}$ & $\begin{array}{c}\text { Sample } \\
\text { time } \\
(\mathrm{hhmm})\end{array}$ & $\begin{array}{l}\text { Phosphorus, } \\
\text { dissolved } \\
\text { (mg/L) }\end{array}$ & $\begin{array}{l}\text { Phosphorus, } \\
\text { total } \\
\text { (mg/L) }\end{array}$ & $\begin{array}{c}\text { Solids, residue } \\
\text { on evaporation } \\
\text { at } 180^{\circ} \mathrm{C}, \\
\text { dissolved } \\
\text { (mg/L) }\end{array}$ & $\begin{array}{l}\text { Dissolved } \\
\text { solids, sum of } \\
\text { constituents } \\
\text { (mg/L) }\end{array}$ & $\begin{array}{c}\text { Aluminum, } \\
\text { dissolved } \\
(\mu \mathrm{g} / \mathrm{L})\end{array}$ & $\begin{array}{c}\text { Antimony, } \\
\text { dissolved } \\
(\mu \mathrm{g} / \mathrm{L})\end{array}$ & $\begin{array}{l}\text { Arsenic, } \\
\text { dissolved } \\
(\mu \mathrm{g} / \mathrm{L})\end{array}$ & $\begin{array}{l}\text { Barium, } \\
\text { dissolved } \\
(\mu \mathrm{g} / \mathrm{L})\end{array}$ & $\begin{array}{c}\text { Beryllium, } \\
\text { dissolved } \\
(\mu \mathrm{g} / \mathrm{L})\end{array}$ & $\begin{array}{l}\text { Boron, } \\
\text { dissolved } \\
(\mu \mathrm{g} / \mathrm{L})\end{array}$ & $\begin{array}{l}\text { Cadmium, } \\
\text { dissolved } \\
(\mu \mathrm{g} / \mathrm{L})\end{array}$ & $\begin{array}{c}\text { Chromium, } \\
\text { dissolved } \\
(\mu \mathrm{g} / \mathrm{L})\end{array}$ & $\begin{array}{c}\text { Cobalt, } \\
\text { dissolved } \\
(\mu \mathrm{g} / \mathrm{L})\end{array}$ \\
\hline$\overline{\mathrm{D} 6 \mathrm{~A}}$ & $11 / 19 / 2007$ & 1230 & E,n 0.04 & E,n 0.04 & 22,400 & 20,000 & $<12.8$ & $<1.12$ & 1.0 & 6 & $<0.06$ & 856 & $<0.32$ & $<0.96$ & 11.4 \\
\hline D6A & 9/18/2008 & 1300 & E,n .03 & E,n .03 & 22,200 & 19,800 & $<12.8$ & $<1.12$ & .92 & 5 & $<.06$ & 709 & $<.32$ & $<.96$ & 8.9 \\
\hline D7 & 9/23/2008 & 1245 & .09 & .09 & 2,280 & 2,170 & $<1.6$ & E,n .09 & .86 & 16 & $<.01$ & 175 & .11 & .17 & .92 \\
\hline D8 & 9/25/2008 & 1520 & E,n. 04 & .04 & 4,450 & $\mathrm{E} 4,080$ & E,n 1.9 & $<.28$ & .85 & 14 & $<.02$ & 151 & .29 & .49 & 1.8 \\
\hline D10 & $11 / 18 / 2007$ & 1300 & .16 & .16 & 4,510 & $\mathrm{E} 4,050$ & $<4.8$ & $<.42$ & 1.7 & 13 & $<.02$ & 423 & $<.12$ & .41 & .18 \\
\hline D13 & 9/29/2008 & 1520 & $<.04$ & E,n .02 & 736 & E713 & $<1.6$ & $<.14$ & .48 & 17 & $<.01$ & 87 & $<.04$ & E,n .08 & .33 \\
\hline D14 & $9 / 26 / 2008$ & 1325 & E,n .03 & E,n .03 & 562 & E549 & E,n .9 & E,n .09 & .95 & 46 & $<.01$ & 96 & E,n .03 & .50 & .31 \\
\hline D15 & 9/25/2008 & 1245 & E,n .02 & E.,n 03 & 4,170 & $\mathrm{E} 3,840$ & $<3.2$ & $<.28$ & 4.0 & 13 & E,n .01 & 389 & $<.08$ & E,n .18 & 11.3 \\
\hline D16 & 9/26/2008 & 1100 & E,n .03 & E,n .03 & 4,100 & 3,740 & $<3.2$ & $<.28$ & 4.8 & 17 & $<.02$ & 132 & .10 & $<.24$ & 5.6 \\
\hline D17 & 3/19/2007 & 1440 & .05 & .08 & 297 & E288 & $<1.6$ & $<.06$ & 1.4 & 55 & $<.06$ & 53 & .04 & E,n .07 & .16 \\
\hline D17 & 6/19/2007 & 0930 & .08 & .08 & 293 & E288 & E,n 1.1 & .08 & 1.4 & 58 & $<.06$ & 53 & E,n .02 & $<.12$ & .11 \\
\hline D17 & 9/5/2007 & 1400 & .07 & .09 & 300 & E289 & $<1.6$ & .06 & 1.4 & 60 & $<.06$ & 58 & $<.04$ & $<.12$ & .13 \\
\hline D17 & 11/20/2007 & 1430 & .08 & .09 & 305 & 288 & $<3.2$ & $<.28$ & 1.5 & 58 & $<.02$ & 61 & $<.08$ & $<.24$ & .12 \\
\hline D17 & $3 / 25 / 2008$ & 1530 & .08 & .07 & 300 & 296 & $<1.6$ & $<.14$ & 1.4 & 58 & $<.01$ & 60 & $<.04$ & $<.12$ & .10 \\
\hline D17 & 6/25/2008 & 1000 & .09 & .08 & 303 & E295 & $<1.6$ & $<.14$ & 1.5 & 55 & $<.01$ & 53 & E,n .02 & $<.12$ & .11 \\
\hline D17 & 9/19/2008 & 0930 & .09 & .08 & 292 & 283 & $<1.6$ & $<.14$ & 1.6 & 59 & $<.01$ & 57 & $<.04$ & $<.12$ & .12 \\
\hline D17 & $11 / 18 / 2008$ & 1430 & .08 & .09 & 300 & E297 & $<4.0$ & .08 & 1.5 & 58 & $<.02$ & 51 & E,n .02 & $<.12$ & .13 \\
\hline D19 & 9/19/2008 & 1115 & .25 & .25 & 222 & E220 & E,n 1.0 & E,n .10 & 1.4 & 75 & $<.01$ & 9.8 & E,n .02 & .37 & .08 \\
\hline D20 & 9/29/2008 & 1240 & .15 & .15 & 2,940 & E2,760 & $<8.0$ & $<.70$ & 6.5 & 16 & $<.04$ & 95 & $<.20$ & $<.60$ & .57 \\
\hline D21 & 9/29/2008 & 1030 & .32 & .60 & 937 & $\mathrm{E} 1,110$ & $<3.2$ & $<.14$ & 11.0 & 82 & E,n .01 & 156 & $<.04$ & E,n .07 & .36 \\
\hline D22 & 9/24/2008 & 1225 & $<.04$ & $<.04$ & 12,700 & 10,800 & $<8.0$ & $<.70$ & .68 & 9 & $<.04$ & 1,160 & $<.20$ & 1.1 & 4.9 \\
\hline D23 & 9/25/2008 & 1015 & .89 & .88 & 4,880 & $\mathrm{E} 4,480$ & E,n 1.6 & .39 & 8.7 & 22 & $<.02$ & 418 & .22 & .90 & 3.8 \\
\hline D25 & 3/20/2007 & 1445 & .09 & .14 & 4,650 & 4,150 & $<3.2$ & .12 & 3.0 & 15 & $<12$ & 415 & $<.08$ & $<.24$ & 1.5 \\
\hline D25 & 6/21/2007 & 1430 & .14 & .14 & 4,540 & $\mathrm{E} 4,180$ & $<4.8$ & E,n. 15 & 2.4 & 16 & $<.18$ & 426 & .24 & $<.36$ & 1.62 \\
\hline D25 & 9/5/2007 & 1645 & .15 & .16 & 4,710 & $\mathrm{E} 4,180$ & $<4.8$ & E,n .15 & 3.1 & 17 & $<.18$ & 546 & .21 & E,n .36 & 2.0 \\
\hline D25 & $11 / 20 / 2007$ & 1600 & .09 & .09 & 4,500 & 4,130 & $<8.0$ & $<.70$ & 1.7 & 18 & $<.04$ & 224 & .22 & $<.60$ & 2.1 \\
\hline D25 & $3 / 26 / 2008$ & 1350 & .08 & .08 & 4,540 & 4,130 & $<3.2$ & $<.28$ & 1.5 & 17 & $<.02$ & 180 & .16 & $<.24$ & 2.4 \\
\hline D25 & 6/25/2008 & 1215 & .09 & .09 & 4,510 & $\mathrm{E} 4,180$ & $<3.2$ & $<.28$ & 1.6 & 15 & $<.02$ & 199 & .20 & E,n. 15 & 2.2 \\
\hline D25 & 9/16/2008 & 1315 & .12 & .13 & 4,500 & 4,040 & $<8.0$ & $<.70$ & 2.3 & 14 & $<.04$ & 334 & .24 & $<.60$ & 1.5 \\
\hline D25 & $11 / 19 / 2008$ & 1515 & .09 & .08 & 4,490 & 4,150 & $<12.0$ & .2 & 1.7 & 16 & $<.06$ & 163 & .24 & $<.36$ & 2.0 \\
\hline D25A & 3/26/2008 & 1530 & .07 & .07 & 4,520 & $\mathrm{E} 4,050$ & $<3.2$ & $<.28$ & .94 & 20 & $<.02$ & 153 & E,n .04 & $<.24$ & 3.0 \\
\hline D26 & 9/16/2008 & 1040 & .10 & .09 & 443 & E428 & $<1.6$ & $<.14$ & .37 & 13 & $<.01$ & 71 & $<.04$ & .52 & .14 \\
\hline D27 & 9/23/2008 & 1015 & .14 & .15 & 2,970 & E2,770 & $<3.2$ & E,n .16 & 1.7 & 16 & $<.02$ & 194 & E,n .05 & .39 & .38 \\
\hline D28 & 9/23/2008 & 1445 & E,n .03 & .05 & 2,820 & $\mathrm{E} 2,600$ & $<3.2$ & $<.28$ & .49 & 13 & $<.02$ & 146 & $<.08$ & .50 & .29 \\
\hline D31 & 11/19/2008 & 1330 & E,n .03 & $<.04$ & 8,420 & $\mathrm{E} 7,680$ & $<20.0$ & .3 & 1.0 & 8 & $<.10$ & 628 & E,n .05 & $<.60$ & .79 \\
\hline D32 & $12 / 20 / 2007$ & 1120 & $<.04$ & E. 02 & 3,680 & $\mathrm{E} 3,400$ & $<4.8$ & $<.42$ & 0.45 & 10 & $<.02$ & 403 & $<.12$ & 2.0 & 0.28 \\
\hline D33 & $11 / 18 / 2007$ & 1500 & .05 & .06 & 4,610 & $\mathrm{E} 4,230$ & $<4.8$ & $<.42$ & 1.2 & 14 & $<.02$ & 277 & $<.12$ & 1.7 & .17 \\
\hline
\end{tabular}



minimum reporting level; <, less than; $\mathrm{M}$, presence verified at very small concentration that could not be quantified]

\begin{tabular}{|c|c|c|c|c|c|c|c|c|c|c|c|c|c|c|c|}
\hline Well name & $\begin{array}{c}\text { Sample } \\
\text { date }\end{array}$ & $\begin{array}{c}\text { Sample } \\
\text { time } \\
(\mathrm{hhmm})\end{array}$ & $\begin{array}{l}\text { Copper, } \\
\text { dissolved } \\
(\mu \mathrm{g} / \mathrm{L})\end{array}$ & $\begin{array}{c}\text { Iron, } \\
\text { dissolved } \\
(\mu \mathrm{g} / \mathrm{L})\end{array}$ & $\begin{array}{l}\text { Lead, } \\
\text { dissolved } \\
(\mu \mathrm{g} / \mathrm{L})\end{array}$ & $\begin{array}{l}\text { Manganese, } \\
\text { dissolved } \\
(\mu \mathrm{g} / \mathrm{L})\end{array}$ & $\begin{array}{l}\text { Mercury, } \\
\text { dissolved } \\
(\mu \mathrm{g} / \mathrm{L})\end{array}$ & $\begin{array}{l}\text { Molybdenum, } \\
\text { dissolved } \\
(\mu \mathrm{g} / \mathrm{L})\end{array}$ & $\begin{array}{l}\text { Nickel, } \\
\text { dissolved } \\
(\mu \mathrm{g} / \mathrm{L})\end{array}$ & $\begin{array}{l}\text { Selenium, } \\
\text { dissolved } \\
(\mu \mathrm{g} / \mathrm{L})\end{array}$ & $\begin{array}{c}\text { Silver, } \\
\text { dissolved } \\
(\mu \mathrm{g} / \mathrm{L})\end{array}$ & $\begin{array}{l}\text { Strontium, } \\
\text { dissolved } \\
(\mu \mathrm{g} / \mathrm{L})\end{array}$ & $\begin{array}{l}\text { Tungsten, } \\
\text { dissolved } \\
(\mu \mathrm{g} / \mathrm{L})\end{array}$ & $\begin{array}{c}\text { Zinc, } \\
\text { dissolved } \\
(\mu \mathrm{g} / \mathrm{L})\end{array}$ & $\begin{array}{l}\text { Uranium, } \\
\text { dissolved } \\
(\mu \mathrm{g} / \mathrm{L})\end{array}$ \\
\hline DTX1 & $3 / 20 / 2007$ & 1145 & E,n 0.56 & $<18$ & $<0.24$ & 225 & $<0.010$ & 4.7 & 17.4 & 6.8 & $<0.2$ & 5,400 & E,n 0.07 & E,n 1.1 & 36.3 \\
\hline DTX1 & $6 / 25 / 2007$ & 1340 & 1.0 & $<18$ & E,n .15 & 250 & $<.010$ & 3.7 & 17.8 & 11.9 & $<.2$ & 5,470 & $<.12$ & E,n 1.1 & 34.2 \\
\hline DTX1 & 9/7/2007 & 0915 & E,n .59 & $<18$ & $<.24$ & 264 & $<.010$ & 4.1 & 22.3 & 10.3 & $<.2$ & 5,520 & $<.12$ & 1.4 & 38.2 \\
\hline DTX1 & $11 / 20 / 2007$ & 0915 & $<3.0$ & $<24$ & $<.24$ & 270 & $<.010$ & 3.9 & 21.4 & 11.8 & $<.3$ & 5,700 & $<.18$ & $<5.4$ & 36.6 \\
\hline DTX1 & $3 / 25 / 2008$ & 1000 & $<2.0$ & $<24$ & $<.16$ & 210 & $<.010$ & 3.5 & 18.3 & 7.4 & $<.2$ & 5,440 & $<.12$ & $<3.6$ & 35.4 \\
\hline DTX1 & $6 / 25 / 2008$ & 1415 & $<2.0$ & $<16$ & $<.16$ & 157 & $<.010$ & 3.4 & 17.2 & 12.7 & $<.2$ & 5,920 & $<.12$ & $<3.6$ & 39.4 \\
\hline DTX1 & 9/17/2008 & 1000 & $<5.0$ & $<24$ & $<.40$ & 169 & $<.010$ & 2.6 & 19.1 & 11.7 & $<.5$ & 5,550 & $<.30$ & $<9.0$ & 38.0 \\
\hline DTX1 & $11 / 18 / 2008$ & 1015 & $<3.0$ & E,n 8 & $<.18$ & 179 & $<.010$ & 2.7 & 16.2 & 13.2 & M & 5,600 & $<.06$ & $<6.0$ & 38.9 \\
\hline DTX2 & 3/20/2007 & 0930 & $<1.2$ & 542 & $<.36$ & 4,600 & $<.010$ & 1.7 & 4.8 & E,n .23 & $<.3$ & 5,500 & $<.18$ & E,n 1.7 & 29.1 \\
\hline DTX2 & 6/25/2007 & 1045 & E,n 1.1 & 480 & E,n .24 & 5,130 & $<.010$ & 1.6 & 4.2 & $<.24$ & $<.3$ & 5,300 & $<.18$ & 2.3 & 29.9 \\
\hline DTX2 & 9/7/2007 & 1125 & $<1.2$ & 552 & $<.36$ & 4,740 & $<.010$ & 1.9 & 6.8 & E,n .16 & $<.3$ & 5,260 & $<.18$ & E,n 1.6 & 32.3 \\
\hline DTX2 & $11 / 20 / 2007$ & 1145 & $<5.0$ & 662 & $<.40$ & 5,500 & $<.010$ & 1.9 & 6.4 & E,n.16 & $<.5$ & 5,700 & $<.30$ & E,n 4.8 & 30.7 \\
\hline DTX2 & 3/25/2008 & 1245 & $<3.0$ & 582 & $<.24$ & 5,670 & $<.010$ & 1.8 & 6.7 & .30 & $<.3$ & 5,420 & $<.18$ & $<5.4$ & 29.9 \\
\hline DTX2 & 6/24/2008 & 1415 & $<3.0$ & 462 & $<.24$ & 5,150 & $<.010$ & 2.0 & 8.8 & .29 & $<.3$ & 5,740 & $<.18$ & $<5.4$ & 32.8 \\
\hline DTX2 & 9/17/2008 & 1200 & $<5.0$ & 589 & $<.40$ & 5,120 & $<.010$ & 1.8 & 9.6 & .23 & $<.5$ & 5,480 & $<.30$ & $<9.0$ & 29.3 \\
\hline DTX2 & $11 / 18 / 2008$ & 1200 & $<4.0$ & 649 & $<.24$ & 5,650 & $<.010$ & 1.9 & 8.0 & E,n .17 & M & 5,350 & $<.08$ & $<8.0$ & 29.5 \\
\hline DTX5 & $11 / 21 / 2008$ & 1015 & $<2.0$ & $<8$ & .13 & 187 & $<.010$ & 1.0 & 6.2 & .15 & M & 5,470 & $<.04$ & $<4.0$ & 49.3 \\
\hline DTX6 & $11 / 21 / 2008$ & 1215 & $<2.0$ & $<8$ & $<.12$ & E,n .2 & $<.010$ & .7 & 3.2 & 3.4 & M & 5,300 & $<.04$ & $<4.0$ & 37.6 \\
\hline DTX8A & 6/20/2007 & 0945 & $<.40$ & 738 & $<.12$ & 88.1 & $<.010$ & .5 & .37 & $<.08$ & $<.1$ & 2,410 & .26 & $<.60$ & .15 \\
\hline DTX8A & 6/24/2008 & 1100 & $<1.0$ & 948 & $<.08$ & 100 & $<.010$ & .5 & 1.1 & .07 & $<.1$ & 2,790 & $<.06$ & $<1.8$ & .15 \\
\hline DTX10A & 6/19/2007 & 1330 & $<.80$ & 4,510 & $<.24$ & 266 & $<.010$ & 1.3 & .74 & E,n.10 & $<.2$ & 5,360 & $<.12$ & $<1.2$ & .16 \\
\hline DTX10A & 6/23/2008 & 1200 & $<2.0$ & 4,510 & $<.16$ & 279 & $<.010$ & 1.4 & 3.6 & .17 & $<.2$ & 5,900 & $<.12$ & $<3.6$ & .14 \\
\hline D3 & 9/18/2008 & 1515 & $<3.0$ & E,n 15 & $<.24$ & 397 & $<.010$ & 1.1 & 13.6 & 46.9 & $<.3$ & 848 & $<.18$ & $<5.4$ & 6.23 \\
\hline D4 & 9/17/2008 & 1400 & E,n . 58 & E,n 4 & $<.08$ & 0.5 & $<.010$ & .8 & 1.5 & 19.6 & $<.1$ & 222 & E,n .03 & E,n 1.7 & 1.76 \\
\hline D5 & $11 / 18 / 2007$ & 1030 & $<3.0$ & $<24$ & $<.24$ & $<.6$ & $<.010$ & 1.1 & 1.9 & 12.1 & $<.3$ & 6,110 & $<.18$ & E,n 4.6 & 13.9 \\
\hline D6 & 3/19/2007 & 1100 & E,n 2.4 & $<120$ & $<.96$ & 4,650 & $<.010$ & 3.5 & 8.1 & 67.3 & $<.8$ & 16,800 & $<.48$ & E,n 2.9 & 173 \\
\hline D6 & $6 / 21 / 2007$ & 0945 & E,n 2.8 & $<90$ & $<1.20$ & 4,230 & $<.010$ & 3.5 & 9.1 & 62.9 & $<1.0$ & 16,700 & $<.60$ & E,n 3.5 & 173 \\
\hline D6 & 9/5/2007 & 1000 & $<10.0$ & $<120$ & $<3.00$ & 3,900 & $<.010$ & 3.9 & 10.6 & 61.8 & $<2.5$ & 17,300 & $<1.5$ & $<15.0$ & 179 \\
\hline D6 & $11 / 19 / 2007$ & 0945 & $<8.0$ & $<120$ & $<.64$ & 4,690 & $<.010$ & 3.9 & 10.2 & 74.4 & $<.8$ & 18,100 & $<.48$ & $<14.4$ & 200 \\
\hline D6 & $3 / 26 / 2008$ & 1045 & $<8.0$ & $<120$ & $<.64$ & 4,460 & $<.010$ & 3.6 & 11.0 & 57.1 & $<.8$ & 17,900 & $<.48$ & $<14.4$ & 167 \\
\hline D6 & $6 / 23 / 2008$ & 1545 & $<7.0$ & $<80$ & $<.56$ & 4,590 & $<.010$ & 4.1 & 13.7 & 61.8 & $<.7$ & 17,600 & $<.42$ & $<12.6$ & 187 \\
\hline D6 & 9/18/2008 & 1045 & $<10.0$ & $<80$ & $<.80$ & 4,190 & $<.010$ & 3.2 & 14.3 & 60.6 & $<1.0$ & 17,500 & $<.60$ & $<18.0$ & 196 \\
\hline D6 & $11 / 19 / 2008$ & 1100 & $<10.0$ & $<40$ & $<.60$ & 3,940 & $<.010$ & 3.4 & 11.5 & 65.1 & E,n .1 & 17,000 & $<.20$ & $<16.0$ & 179 \\
\hline
\end{tabular}


Table 10. Water-quality data for groundwater samples collected at U.S. Geological Survey monitoring wells near Deer Trail, Colorado, 2007 and 2008.--Continued

$\left[{ }^{\circ} \mathrm{C}\right.$, degrees Celsius; $\mathrm{mg} / \mathrm{L}$, milligrams per liter; $\mu \mathrm{S} / \mathrm{cm}$, microsiemens per centimeter at 25 degrees Celsius; $\mathrm{CaCO}_{3}$, calcium carbonate; $\mathrm{SiO}_{2}$, silicon dioxide; $\mathrm{N}$, nitrogen; $\mu \mathrm{g} / \mathrm{L}$ micrograms per liter; $\mathrm{E}$, value estimated by laboratory; --, no data available; $\mathrm{n}$, value is less than the minimum reporting level: < less than: M, presence verified at very small concentration that could not be quantified]

\begin{tabular}{|c|c|c|c|c|c|c|c|c|c|c|c|c|c|c|c|}
\hline Well name & $\begin{array}{c}\text { Sample } \\
\text { date }\end{array}$ & $\begin{array}{c}\text { Sample } \\
\text { time } \\
(\mathrm{hhmm})\end{array}$ & $\begin{array}{c}\text { Copper, } \\
\text { dissolved } \\
(\mu \mathrm{g} / \mathrm{L})\end{array}$ & $\begin{array}{c}\text { Iron, } \\
\text { dissolved } \\
(\mu \mathrm{g} / \mathrm{L})\end{array}$ & $\begin{array}{l}\text { Lead, } \\
\text { dissolved } \\
(\mu \mathrm{g} / \mathrm{L})\end{array}$ & $\begin{array}{l}\text { Manganese, } \\
\text { dissolved } \\
(\mu \mathrm{g} / \mathrm{L})\end{array}$ & $\begin{array}{l}\text { Mercury, } \\
\text { dissolved } \\
(\mu \mathrm{g} / \mathrm{L})\end{array}$ & $\begin{array}{l}\text { Molybdenum, } \\
\text { dissolved } \\
(\mu \mathrm{g} / \mathrm{L})\end{array}$ & $\begin{array}{c}\text { Nickel, } \\
\text { dissolved } \\
(\mu \mathrm{g} / \mathrm{L})\end{array}$ & $\begin{array}{l}\text { Selenium, } \\
\text { dissolved } \\
(\mu \mathrm{g} / \mathrm{L})\end{array}$ & $\begin{array}{c}\text { Silver, } \\
\text { dissolved } \\
(\mu \mathrm{g} / \mathrm{L})\end{array}$ & $\begin{array}{l}\text { Strontium, } \\
\text { dissolved } \\
(\mu \mathrm{g} / \mathrm{L})\end{array}$ & $\begin{array}{l}\text { Tungsten, } \\
\text { dissolved } \\
(\mu \mathrm{g} / \mathrm{L})\end{array}$ & $\begin{array}{c}\text { Zinc, } \\
\text { dissolved } \\
(\mu \mathrm{g} / \mathrm{L})\end{array}$ & $\begin{array}{c}\text { Uranium, } \\
\text { dissolved } \\
(\mu \mathrm{g} / \mathrm{L})\end{array}$ \\
\hline D6A & $11 / 19 / 2007$ & 1230 & 2.8 & $<120$ & $<0.64$ & 5,060 & $<0.010$ & 4.1 & 13.3 & 56.9 & $<0.8$ & 17,100 & $<0.48$ & $<14.4$ & 210 \\
\hline D6A & 9/18/2008 & 1300 & $<8.0$ & $<80$ & $<.64$ & 4,140 & $<.010$ & 3.5 & 14.9 & 64.6 & $<.8$ & 17,100 & $<.48$ & $<14.4$ & 196 \\
\hline D7 & 9/23/2008 & 1245 & $<1.0$ & $<16$ & $<.08$ & 598 & $<.010$ & 1.0 & 3.4 & 5.4 & $<.1$ & 1,810 & $<.06$ & $<1.8$ & 24.2 \\
\hline D8 & 9/25/2008 & 1520 & $<2.0$ & $<24$ & $<.16$ & 3,600 & $<.010$ & 4.5 & 8.4 & .20 & $<.2$ & 3,500 & $<.12$ & $<3.6$ & 17.8 \\
\hline D10 & $11 / 18 / 2007$ & 1300 & E,n 1.9 & $<24$ & $<.24$ & $<.6$ & $<.010$ & 2.4 & 1.1 & 14 & $<.3$ & 7,280 & $<.18$ & E,n 2.9 & 27.9 \\
\hline D13 & 9/29/2008 & 1520 & $<1.0$ & 17 & $<.08$ & 96.6 & $<.010$ & 1.2 & 1.0 & .12 & $<.1$ & 778 & $<.06$ & $<1.8$ & 4.46 \\
\hline D14 & 9/26/2008 & 1325 & $<1.0$ & $<8$ & $<.08$ & 196 & $<.010$ & 3.3 & 1.4 & 16.7 & $<.1$ & 437 & $<.06$ & $<1.8$ & 9.22 \\
\hline D15 & 9/25/2008 & 1245 & $<2.0$ & 3,500 & E,n .10 & 6,220 & $<.010$ & 4.7 & 12.7 & .21 & $<.2$ & 5,820 & $<.12$ & E,n 2.8 & 28.7 \\
\hline D16 & 9/26/2008 & 1100 & $<2.0$ & 3,330 & $<.16$ & 2,880 & $<.010$ & 6.4 & 8.4 & .14 & $<.2$ & 4,420 & $<.12$ & $<3.6$ & 26.7 \\
\hline D17 & 3/19/2007 & 1440 & $<.40$ & $<6$ & $<.12$ & 256 & $<.010$ & 6.3 & .55 & 7.8 & $<.1$ & 302 & $<.06$ & $<.60$ & 3.73 \\
\hline D17 & 6/19/2007 & 0930 & $<.40$ & $<6$ & $<.12$ & 342 & $<.010$ & 5.8 & .61 & 7.5 & $<.1$ & 297 & $<.06$ & $<.60$ & 4.11 \\
\hline D17 & 9/5/2007 & 1400 & E,n .21 & $<6$ & $<.12$ & 359 & $<.010$ & 5.6 & .82 & 7.3 & $<.1$ & 314 & $<.06$ & $<.60$ & 3.95 \\
\hline D17 & $11 / 20 / 2007$ & 1430 & $<2.0$ & $<8$ & $<.16$ & 349 & $<.010$ & 5.5 & .82 & 7.2 & $<.2$ & 314 & $<.12$ & $<1.8$ & 3.93 \\
\hline D17 & $3 / 25 / 2008$ & 1530 & $<1.0$ & $<8$ & $<.08$ & 192 & $<.010$ & 5.3 & .66 & 7.4 & $<.1$ & 314 & $<.06$ & $<1.8$ & 3.68 \\
\hline D17 & $6 / 25 / 2008$ & 1000 & $<1.0$ & $<8$ & $<.08$ & 243 & $<.010$ & 5.5 & .88 & 7.6 & $<.1$ & 306 & $<.06$ & $<1.8$ & 4.28 \\
\hline D17 & 9/19/2008 & 0930 & $<1.0$ & $<8$ & $<.08$ & 309 & $<.010$ & 5.5 & .78 & 8.8 & $<.1$ & 319 & $<.06$ & $<1.8$ & 4.07 \\
\hline D17 & $11 / 18 / 2008$ & 1430 & $<1.0$ & E,n 2 & $<.06$ & 355 & $<.010$ & 5.6 & .88 & 7.7 & $<.008$ & 308 & $<.02$ & $<2.0$ & 3.97 \\
\hline D19 & 9/19/2008 & 1115 & $<1.0$ & $<8$ & $<.08$ & $<.2$ & $<.010$ & 1.7 & .55 & 8.8 & $<.1$ & 195 & $<.06$ & $<1.8$ & 2.05 \\
\hline D20 & 9/29/2008 & 1240 & $<5.0$ & $<16$ & $<.40$ & 644 & $<.010$ & 4.3 & 6.0 & E,n .15 & $<.5$ & 1,860 & $<.30$ & $<9.0$ & 6.99 \\
\hline D21 & 9/29/2008 & 1030 & $<1.0$ & 17,700 & $<.08$ & 3,710 & $<.010$ & 4.0 & .95 & .19 & $<.1$ & 2,130 & $<.06$ & $<1.8$ & .34 \\
\hline D22 & $9 / 24 / 2008$ & 1225 & $<5.0$ & 74 & $<.40$ & 1,540 & $<.010$ & 2.1 & 10.9 & 2.3 & $<.5$ & 8,850 & $<.30$ & $<9.0$ & 221 \\
\hline D23 & 9/25/2008 & 1015 & 3.4 & 48 & $<.16$ & 9,020 & $<.010$ & 13.3 & 13.2 & 3.1 & $<.2$ & 5,790 & $<.12$ & E,n 3.3 & 92.1 \\
\hline D25 & $3 / 20 / 2007$ & 1445 & .98 & $<18$ & $<.24$ & 1,870 & $<.010$ & 9.0 & 3.8 & 6.7 & $<.2$ & 3,480 & 0.2 & $<1.2$ & 35.7 \\
\hline D25 & $6 / 21 / 2007$ & 1430 & E,n 1.1 & $<18$ & $<.36$ & 2,340 & $<.010$ & 10.0 & 4.3 & 7.5 & $<.3$ & 3,660 & $<.18$ & $<1.8$ & 39.0 \\
\hline D25 & 9/5/2007 & 1645 & 1.3 & E,n 4 & $<.36$ & 2,580 & $<.010$ & 11.7 & 6.6 & 7.9 & $<.3$ & 3,560 & $<.18$ & $<1.8$ & 41.3 \\
\hline D25 & $11 / 20 / 2007$ & 1600 & $<5.0$ & $<24$ & $<.40$ & 2,640 & $<.010$ & 7.0 & 4.8 & 1.7 & $<.5$ & 3,460 & $<.30$ & $<9.0$ & 28.4 \\
\hline D25 & $3 / 26 / 2008$ & 1350 & $<2.0$ & $<24$ & $<.16$ & 2,610 & $<.010$ & 6.1 & 6.1 & .97 & $<.2$ & 3,480 & $<.12$ & $<3.6$ & 26.9 \\
\hline D25 & 6/25/2008 & 1215 & $<2.0$ & $<24$ & $<.16$ & 2,950 & $<.010$ & 6.9 & 7.2 & 1.9 & $<.2$ & 3,820 & $<.12$ & $<3.6$ & 31.2 \\
\hline D25 & $9 / 16 / 2008$ & 1315 & $<5.0$ & $<24$ & $<.40$ & 2,410 & $<.010$ & 10.2 & 13.6 & 4.2 & $<.5$ & 3,350 & $<.30$ & $<9.0$ & 40.8 \\
\hline D25 & $11 / 19 / 2008$ & 1515 & $<3.0$ & $<12$ & $<.18$ & 3,050 & $<.010$ & 7.3 & 7.5 & .75 & $<.024$ & 3,370 & $<.06$ & $<6.0$ & 30.7 \\
\hline D25A & $3 / 26 / 2008$ & 1530 & $<2.0$ & 266 & $<.16$ & 3,430 & $<.010$ & 5.2 & 6.0 & .24 & $<.2$ & 3,340 & $<.12$ & $<3.6$ & 23.1 \\
\hline D26 & $9 / 16 / 2008$ & 1040 & E,n .60 & $<8$ & $<.08$ & .9 & $<.010$ & 2.5 & .82 & 7.1 & $<.1$ & 568 & $<.06$ & $<1.8$ & 14.1 \\
\hline D27 & $9 / 23 / 2008$ & 1015 & $<2.0$ & $<16$ & $<.16$ & 6.4 & $<.010$ & 1.0 & 3.4 & 2.4 & $<.2$ & 2,030 & $<.12$ & $<3.6$ & 19.4 \\
\hline D28 & 9/23/2008 & 1445 & E,n 1.1 & $<16$ & $<.16$ & 10.0 & $<.010$ & .8 & 2.8 & 16.8 & $<.2$ & 2,440 & $<.12$ & $<3.6$ & 17.2 \\
\hline D31 & 11/19/2008 & 1330 & $<5.0$ & $<16$ & $<.30$ & 270 & $<.010$ & 3.8 & 6.3 & 1.9 & M & 9,260 & $<.10$ & $<10.0$ & 52.4 \\
\hline D32 & $12 / 20 / 2007$ & 1120 & $<3$ & E,n 9.9 & E,n .13 & E,n .43 & $<.010$ & 1.1 & 4.1 & 16.0 & $<.3$ & 6,290 & $<.18$ & $<5.4$ & 34.7 \\
\hline D33 & $11 / 18 / 2007$ & 1500 & $<3.0$ & $<24$ & $<.08$ & 1.9 & $<.010$ & 1.3 & 1.0 & 106 & $<.3$ & 5,410 & $<.18$ & E,n 1.1 & 11.4 \\
\hline
\end{tabular}

${ }^{1}$ Inflection-point titration done in Denver within 24 hours of sample collection. 
[Site name refers to site where sample was processed or, for equipment blank, site where equipment was last used; $\mu \mathrm{S} / \mathrm{cm}$, microsiemens per centimeter at $25 \mathrm{degrees}$ Celsius; $\mathrm{mg} / \mathrm{L}$, milligrams per liter; $\mathrm{CaCO}$, calcium carbonate; $\mathrm{SiO}_{2}$, silicon dioxide; $\mathrm{N}$, nitrogen; ${ }^{\circ} \mathrm{C}$, degrees Celsius; $\mu \mathrm{g} / \mathrm{L}$, micrograms per liter; $\mathrm{F}$, field blank; <, less than; E, value estimated by laboratory; $\mathrm{n}$, value is less than the minimum reporting level; Q, equipment blank; S, source-water blank; --, no sample submitted; M, presence of material verified but not quantified]

\begin{tabular}{|c|c|c|c|c|c|c|c|c|c|c|c|}
\hline $\begin{array}{c}\text { Blank } \\
\text { type }\end{array}$ & $\begin{array}{c}\text { Sample } \\
\text { date }\end{array}$ & $\begin{array}{c}\text { Sample } \\
\text { time } \\
\text { (hhmm) }\end{array}$ & $\begin{array}{c}\text { Site } \\
\text { name }\end{array}$ & $\begin{array}{c}\text { Specific } \\
\text { conductance, } \\
\text { laboratory } \\
(\mu \mathrm{S} / \mathrm{cm})\end{array}$ & $\begin{array}{c}\mathrm{pH}, \\
\text { laboratory } \\
\text { (standard } \\
\text { units) }\end{array}$ & $\begin{array}{c}\text { Calcium, } \\
\text { dissolved } \\
\text { (mg/L) }\end{array}$ & $\begin{array}{c}\text { Magnesium, } \\
\text { dissolved } \\
\text { (mg/L) }\end{array}$ & $\begin{array}{c}\text { Potassium, } \\
\text { dissolved } \\
\text { (mg/L) }\end{array}$ & $\begin{array}{c}\text { Sodium, } \\
\text { dissolved } \\
\text { (mg/L) }\end{array}$ & $\begin{array}{c}\text { Acid } \\
\text { neutralizing } \\
\text { capacity, } \\
\text { titration to } \\
\text { pH } 4.5 \\
\text { laboratory, } \\
\text { (mg/L as CaCO })\end{array}$ & $\begin{array}{c}\text { Chloride, } \\
\text { dissolved } \\
(\mathrm{mg} / \mathrm{L})\end{array}$ \\
\hline F & $3 / 20 / 2007$ & 0830 & DTX2 & 6 & 8.4 & $<0.02$ & $<0.014$ & $<0.04$ & $<0.20$ & $<5$ & $<0.12$ \\
\hline Q & $6 / 20 / 2007$ & 1515 & DTX8A & 6 & 8.3 & E,n.02 & E,n.009 & $<.04$ & $<.20$ & $<5$ & $<.12$ \\
\hline F & $6 / 25 / 2007$ & 1000 & DTX2 & 3 & 8.2 & $<.02$ & E,n.013 & $<.04$ & $<.20$ & $<5$ & $<.12$ \\
\hline F & $9 / 5 / 2007$ & 1315 & D17 & 5 & 6.6 & $<.02$ & $<.014$ & $<.04$ & $<.20$ & $<5$ & $<.12$ \\
\hline F & $11 / 20 / 2007$ & 1045 & DTX2 & $<3$ & 7.4 & $<.04$ & $<.020$ & $<.02$ & $<.12$ & $<6$ & $<.12$ \\
\hline $\mathrm{S}^{1}$ & $12 / 26 / 2007$ & 1350 & DTX2 & -- & 5 & $<.04$ & $<.020$ & $<.02$ & $<.12$ & -- & $<.12$ \\
\hline F & $3 / 26 / 2008$ & 1230 & D25 & $<3$ & 8.2 & $<.04$ & $<.020$ & $<.02$ & $<.12$ & $<6$ & $<.12$ \\
\hline Q & $6 / 24 / 2008$ & 1730 & DTX8A & $<8$ & 7.6 & E,n.02 & $<.020$ & $<.02$ & $<.12$ & $<6$ & $<.12$ \\
\hline Q & $6 / 24 / 2008$ & 1745 & DTX8A & -- & -- & $<.04$ & $<.020$ & $<.02$ & $<.12$ & -- & $<.12$ \\
\hline S & $6 / 24 / 2008$ & 1930 & DTX8A & -- & -- & $<.04$ & $<.020$ & $<.02$ & $<.12$ & -- & $<.12$ \\
\hline F & $6 / 24 / 2008$ & 1245 & DTX2 & $<8$ & 7.6 & $<.04$ & $<.020$ & $<.02$ & $<.12$ & E,n3 & $<.12$ \\
\hline F & $9 / 17 / 2008$ & 0845 & DTX1 & $<8$ & 8.2 & $<.04$ & $<.020$ & $<.02$ & $<.12$ & $<6$ & $<.12$ \\
\hline F & $9 / 26 / 2008$ & 1059 & D16 & $<8$ & 7.5 & .37 & .026 & $<.02$ & $<.12$ & E,n4 & $<.12$ \\
\hline $\mathrm{F}$ & $11 / 18 / 2008$ & 1345 & D17 & $<5$ & 7.9 & $<.02$ & $<.012$ & $<.06$ & $<.12$ & $<8$ & $<.12$ \\
\hline
\end{tabular}


Table 11. Quality-control data for blank samples associated with groundwater samples collected near Deer Trail, Colorado, 2007 and 2008.—Continued

[Site name refers to site where sample was processed or, for equipment blank, site where equipment was last used; $\mu \mathrm{S} / \mathrm{cm}$, microsiemens per centimeter at $25 \mathrm{degrees}$ Celsius; $\mathrm{mg} / \mathrm{L}$, milligrams per liter; $\mathrm{CaCO}_{3}$, calcium carbonate; $\mathrm{SiO}_{2}$, silicon dioxide; $\mathrm{N}$, nitrogen; ${ }^{\circ} \mathrm{C}$, degrees Celsius; $\mu \mathrm{g} / \mathrm{L}$, micrograms per liter; $\mathrm{F}$, field blank; <, less than; $\mathrm{E}$, value estimated by laboratory; $\mathrm{n}$, value is less than the minimum reporting level; Q, equipment blank; S, source-water blank; --, no sample submitted; M, presence of material verified but not quantified]

\begin{tabular}{|c|c|c|c|c|c|c|c|c|c|c|c|c|}
\hline $\begin{array}{c}\text { Blank } \\
\text { type }\end{array}$ & $\begin{array}{c}\text { Sample } \\
\text { date }\end{array}$ & $\begin{array}{c}\text { Fluoride, } \\
\text { dissolved } \\
\text { (mg/L) }\end{array}$ & $\begin{array}{c}\text { Silica, } \\
\text { dissolved } \\
\text { (mg/L as } \\
\mathrm{SiO}_{2} \text { ) }\end{array}$ & $\begin{array}{c}\text { Sulfate, } \\
\text { dissolved } \\
\text { (mg/L) }\end{array}$ & $\begin{array}{l}\text { Nitrogen, } \\
\text { ammonia } \\
\text { plus } \\
\text { organic, } \\
\text { dissolved } \\
\text { (mg/L as N) }\end{array}$ & $\begin{array}{l}\text { Nitrogen, } \\
\text { ammonia } \\
\text { plus } \\
\text { organic, } \\
\text { total } \\
\text { (mg/L as } \mathrm{N} \text { ) }\end{array}$ & $\begin{array}{l}\text { Nitrogen, } \\
\text { ammonia, } \\
\text { dissolved } \\
\text { (mg/L as N) }\end{array}$ & $\begin{array}{c}\text { Nitrite } \\
\text { plus nitrate, } \\
\text { dissolved } \\
\text { (mg/L as N) }\end{array}$ & $\begin{array}{c}\text { Phosphorus, } \\
\text { dissolved } \\
\text { (mg/L) }\end{array}$ & $\begin{array}{c}\text { Phosphorus } \\
\text { total } \\
\text { (mg/L) }\end{array}$ & $\begin{array}{c}\text { Solids, } \\
\text { residue on } \\
\text { evaporation } \\
\text { at } 180^{\circ} \mathrm{C} \text {, } \\
\text { dissolved } \\
\text { (mg/L) }\end{array}$ & $\begin{array}{c}\text { Aluminum, } \\
\text { dissolved } \\
(\mu \mathrm{g} / \mathrm{L})\end{array}$ \\
\hline $\mathrm{F}$ & $3 / 20 / 2007$ & $<0.10$ & $<0.02$ & $<0.18$ & $<0.10$ & $<0.10$ & $<0.040$ & $<0.04$ & $<0.04$ & $<0.04$ & $<10$ & $<1.6$ \\
\hline Q & $6 / 20 / 2007$ & E,n.06 & $<.02$ & $<.18$ & $<.10$ & $<.10$ & $<.040$ & $<.04$ & $<.04$ & $<.04$ & $<10$ & E,n1.2 \\
\hline $\mathrm{F}$ & $6 / 25 / 2007$ & $<.10$ & E,n.01 & $<.18$ & E,n.08 & $<.10$ & $<.040$ & $<.04$ & $<.04$ & $<.04$ & $<10$ & $<1.6$ \\
\hline $\mathrm{F}$ & $9 / 5 / 2007$ & $<.10$ & $<.02$ & $<.18$ & $<.10$ & $<.10$ & $<.040$ & $<.04$ & $<.04$ & $<.04$ & $<10$ & $<1.6$ \\
\hline $\mathrm{F}$ & $11 / 20 / 2007$ & $<.12$ & $<.02$ & $<.18$ & $<.14$ & $<.14$ & $<.040$ & $<.04$ & $<.04$ & $<.04$ & $<10$ & $<3.2$ \\
\hline $\mathrm{S}^{1}$ & $12 / 26 / 2007$ & $<.12$ & $<.02$ & $<.18$ & -- & -- & -- & -- & -- & -- & -- & $<1.6$ \\
\hline $\mathrm{F}$ & $3 / 26 / 2008$ & $<.12$ & $<.02$ & $<.18$ & $<.14$ & $<.14$ & $<.040$ & $<.04$ & $<.04$ & $<.04$ & $<10$ & $<1.6$ \\
\hline Q & $6 / 24 / 2008$ & $<.12$ & $<.02$ & $<.18$ & $<.14$ & $<.14$ & $<.040$ & $<.04$ & $<.04$ & $<.04$ & $<10$ & E,n1.0 \\
\hline Q & $6 / 24 / 2008$ & $<.12$ & $<.02$ & $<.18$ & -- & -- & -- & -- & -- & -- & $<10$ & 3.3 \\
\hline$S$ & $6 / 24 / 2008$ & $<.12$ & $<.02$ & $<.18$ & -- & -- & -- & -- & -- & -- & $<10$ & $<1.6$ \\
\hline $\mathrm{F}$ & $6 / 24 / 2008$ & $<.12$ & $<.02$ & $<.18$ & $<.14$ & $<.14$ & $<.040$ & $<.04$ & $<.04$ & $<.04$ & $<10$ & $<1.6$ \\
\hline $\mathrm{F}$ & $9 / 17 / 2008$ & $<.12$ & $<.02$ & $<.18$ & $<.14$ & $<.14$ & $<.040$ & $<.04$ & $<.04$ & $<.04$ & $<10$ & $<1.6$ \\
\hline $\mathrm{F}$ & 9/26/2008 & $<.12$ & E,n.02 & $<.18$ & $<.14$ & $<.14$ & $<.040$ & $<.04$ & $<.04$ & $<.04$ & $<10$ & 1.6 \\
\hline $\mathrm{F}$ & $11 / 18 / 2008$ & $<.08$ & $<.02$ & $<.18$ & $<.10$ & $<.10$ & $<.040$ & E,n.02 & $<.04$ & $<.04$ & $<10$ & $<4.0$ \\
\hline
\end{tabular}


[Site name refers to site where sample was processed or, for equipment blank, site where equipment was last used; $\mu \mathrm{S} / \mathrm{cm}$, microsiemens per centimeter at $25 \mathrm{degrees}$ Celsius; mg/L, milligrams per liter; $\mathrm{CaCO}_{3}$, calcium carbonate; $\mathrm{SiO}_{2}$, silicon dioxide; $\mathrm{N}$, nitrogen; ${ }^{\circ} \mathrm{C}$, degrees Celsius; $\mu \mathrm{g} / \mathrm{L}$, micrograms per liter; $\mathrm{F}$, field blank; <, less than; E, value estimated by laboratory; $\mathrm{n}$, value is less than the minimum reporting level; Q, equipment blank; S, source-water blank; --, no sample submitted; M, presence of material verified but not quantified]

\begin{tabular}{|c|c|c|c|c|c|c|c|c|c|c|c|c|}
\hline $\begin{array}{l}\text { Blank } \\
\text { type }\end{array}$ & $\begin{array}{c}\text { Sample } \\
\text { date }\end{array}$ & $\begin{array}{c}\text { Antimony, } \\
\text { dissolved } \\
(\mu \mathrm{g} / \mathrm{L})\end{array}$ & $\begin{array}{c}\text { Arsenic, } \\
\text { dissolved } \\
(\mu \mathrm{g} / \mathrm{L})\end{array}$ & $\begin{array}{c}\text { Barium, } \\
\text { dissolved } \\
(\mu \mathrm{g} / \mathrm{L})\end{array}$ & $\begin{array}{c}\text { Beryllium, } \\
\text { dissolved } \\
(\mu \mathrm{g} / \mathrm{L})\end{array}$ & $\begin{array}{c}\text { Boron, } \\
\text { dissolved } \\
(\mu \mathrm{g} / \mathrm{L})\end{array}$ & $\begin{array}{c}\text { Bromide, } \\
\text { dissolved } \\
(\mu \mathrm{g} / \mathrm{L})\end{array}$ & $\begin{array}{c}\text { Cadmium, } \\
\text { dissolved } \\
(\mu \mathrm{g} / \mathrm{L})\end{array}$ & $\begin{array}{c}\text { Chromium, } \\
\text { dissolved } \\
(\mu \mathrm{g} / \mathrm{L})\end{array}$ & $\begin{array}{c}\text { Cobalt, } \\
\text { dissolved } \\
\text { ( } \mu \mathrm{g} / \mathrm{L})\end{array}$ & $\begin{array}{c}\text { Copper, } \\
\text { dissolved } \\
(\mu \mathrm{g} / \mathrm{L})\end{array}$ & $\begin{array}{c}\text { Iron, } \\
\text { dissolved } \\
(\mu \mathrm{g} / \mathrm{L})\end{array}$ \\
\hline F & $3 / 20 / 2007$ & $<0.06$ & $<0.12$ & $<0.08$ & $<0.06$ & $<1.8$ & $<0.02$ & $<0.04$ & $<0.12$ & $<0.04$ & $<0.40$ & $<6$ \\
\hline Q & $6 / 20 / 2007$ & $<.06$ & $<.12$ & M & $<.06$ & $<1.8$ & $<.02$ & $<.04$ & $<.12$ & $<.04$ & E,n.29 & $<6$ \\
\hline $\mathrm{F}$ & $6 / 25 / 2007$ & $<.06$ & $<.12$ & $<.08$ & $<.06$ & $<1.8$ & $<.02$ & $<.04$ & $<.12$ & $<.04$ & $<.40$ & $<6$ \\
\hline $\mathrm{F}$ & 9/5/2007 & $<.06$ & $<.12$ & $<.08$ & $<.06$ & $<1.8$ & $<.02$ & $<.04$ & $<.12$ & $<.04$ & $<.40$ & $<6$ \\
\hline $\mathrm{F}$ & $11 / 20 / 2007$ & $<.28$ & $<.12$ & $<.8$ & $<.02$ & $<1.2$ & $<.02$ & $<.08$ & $<.24$ & $<.04$ & $<2.0$ & $<8$ \\
\hline $\mathrm{S}^{1}$ & $12 / 26 / 2007$ & $<.14$ & $<.06$ & $<.4$ & $<.01$ & $<1.2$ & $<.02$ & $<.04$ & $<.12$ & $<.02$ & $<1.0$ & $<8$ \\
\hline $\mathrm{F}$ & $3 / 26 / 2008$ & $<.14$ & $<.06$ & $<.4$ & $<.01$ & $<1.2$ & $<.02$ & $<.04$ & $<.12$ & $<.02$ & $<1.0$ & $<8$ \\
\hline Q & $6 / 24 / 2008$ & $<.14$ & $<.06$ & $<.4$ & $<.01$ & 2.3 & $<.02$ & $<.04$ & $<.12$ & .08 & 1.1 & $<8$ \\
\hline Q & $6 / 24 / 2008$ & $<.14$ & $<.06$ & $<.4$ & $<.01$ & 4.1 & -- & $<.04$ & $<.12$ & .03 & $<1.0$ & $<8$ \\
\hline S & $6 / 24 / 2008$ & $<.14$ & $<.06$ & $<.4$ & $<.01$ & E,n1.1 & -- & $<.04$ & $<.12$ & $<.02$ & $<1.0$ & $<8$ \\
\hline $\mathrm{F}$ & $6 / 24 / 2008$ & $<.14$ & $<.06$ & $<.4$ & $<.01$ & $<1.2$ & $<.02$ & $<.04$ & $<.12$ & $<.02$ & $<1.0$ & $<8$ \\
\hline $\mathrm{F}$ & $9 / 17 / 2008$ & $<.14$ & $<.06$ & $<.4$ & $<.01$ & $<1.2$ & $<.02$ & $<.04$ & $<.12$ & $<.02$ & $<1.0$ & $<8$ \\
\hline $\mathrm{F}$ & $9 / 26 / 2008$ & $<.14$ & $<.06$ & $<.4$ & $<.01$ & $<1.2$ & $<.02$ & $<.04$ & $<.12$ & $<.02$ & E,n.75 & $<8$ \\
\hline $\mathrm{F}$ & $11 / 18 / 2008$ & $<.04$ & $<.06$ & $<.4$ & $<.02$ & $<2.0$ & $<.02$ & $<.02$ & $<.12$ & $<.02$ & $<1.0$ & $<4$ \\
\hline
\end{tabular}


Table 11. Quality-control data for blank samples associated with groundwater samples collected near Deer Trail, Colorado, 2007 and 2008. - Continued

[Site name refers to site where sample was processed or, for equipment blank, site where equipment was last used; $\mu \mathrm{S} / \mathrm{cm}$, microsiemens per centimeter at $25 \mathrm{degrees}$ Celsius; $\mathrm{mg} / \mathrm{L}$, milligrams per liter; $\mathrm{CaCO}_{3}$, calcium carbonate; $\mathrm{SiO}_{2}$, silicon dioxide; $\mathrm{N}$, nitrogen; ${ }^{\circ} \mathrm{C}$, degrees Celsius; $\mu \mathrm{g} / \mathrm{L}$, micrograms per liter; $\mathrm{F}$, field blank; <, less than; $\mathrm{E}$, value estimated by laboratory; $\mathrm{n}$, value is less than the minimum reporting level; Q, equipment blank; S, source-water blank; --, no sample submitted; M, presence of material verified but not quantified]

\begin{tabular}{|c|c|c|c|c|c|c|c|c|c|c|c|c|}
\hline $\begin{array}{l}\text { Blank } \\
\text { type }\end{array}$ & $\begin{array}{c}\text { Sample } \\
\text { date }\end{array}$ & $\begin{array}{l}\text { Lead, } \\
\text { dissolved } \\
\text { ( } \mu \mathrm{g} / \mathrm{L})\end{array}$ & $\begin{array}{c}\text { Manganese, } \\
\text { dissolved } \\
(\mu \mathrm{g} / \mathrm{L})\end{array}$ & $\begin{array}{c}\text { Mercury, } \\
\text { dissolved } \\
(\mu \mathrm{g} / \mathrm{L})\end{array}$ & $\begin{array}{c}\text { Molybdenum, } \\
\text { dissolved } \\
(\mu \mathrm{g} / \mathrm{L})\end{array}$ & $\begin{array}{c}\text { Nickel, } \\
\text { dissolved } \\
(\mu \mathrm{g} / \mathrm{L})\end{array}$ & $\begin{array}{c}\text { Selenium, } \\
\text { dissolved } \\
(\mu \mathrm{g} / \mathrm{L})\end{array}$ & $\begin{array}{c}\text { Silver, } \\
\text { dissolved } \\
(\mu \mathrm{g} / \mathrm{L})\end{array}$ & $\begin{array}{c}\text { Strontium, } \\
\text { dissolved } \\
(\mu \mathrm{g} / \mathrm{L})\end{array}$ & $\begin{array}{c}\text { Tungsten, } \\
\text { dissolved } \\
(\mu \mathrm{g} / \mathrm{L})\end{array}$ & $\begin{array}{c}\text { Zinc, } \\
\text { dissolved } \\
\text { ( } \mu \mathrm{g} / \mathrm{L})\end{array}$ & $\begin{array}{c}\text { Uranium, } \\
\text { dissolved } \\
\text { ( } \mu \mathrm{g} / \mathrm{L})\end{array}$ \\
\hline $\mathrm{F}$ & $3 / 20 / 2007$ & $<0.12$ & $<0.2$ & $<0.010$ & $<0.1$ & $<0.06$ & $<0.08$ & $<0.1$ & $<0.6$ & $<0.06$ & $<0.60$ & $<0.04$ \\
\hline Q & 6/20/2007 & $<.12$ & $<.2$ & $<.010$ & $<.1$ & E,n.04 & $<.08$ & $<.1$ & $<.6$ & $<.06$ & $<.60$ & $<.04$ \\
\hline $\mathrm{F}$ & $6 / 25 / 2007$ & $<.12$ & E,n.2 & $<.010$ & $<.1$ & $<.06$ & $<.08$ & $<.1$ & $<.6$ & $<.06$ & $<.60$ & $<.04$ \\
\hline $\mathrm{F}$ & $9 / 5 / 2007$ & $<.12$ & $<.2$ & $<.010$ & $<.1$ & $<.06$ & $<.08$ & $<.1$ & $<.6$ & $<.06$ & $<.60$ & $<.04$ \\
\hline $\mathrm{F}$ & $11 / 20 / 2007$ & $<.16$ & $<.4$ & $<.010$ & $<.4$ & $<.40$ & $<.08$ & $<.2$ & $<.4$ & $<.12$ & $<3.6$ & $<.04$ \\
\hline $\mathrm{S}^{1}$ & $12 / 26 / 2007$ & $<.08$ & $<.2$ & $<.010$ & $<.2$ & $<.20$ & $<.04$ & $<.1$ & $<.4$ & E,n.03 & $<1.8$ & $<.02$ \\
\hline $\mathrm{F}$ & $3 / 26 / 2008$ & $<.08$ & $<.2$ & $<.010$ & $<.2$ & $<.20$ & $<.04$ & $<.1$ & $<.4$ & $<.06$ & $<1.8$ & $<.02$ \\
\hline Q & $6 / 24 / 2008$ & .10 & $<.2$ & $<.010$ & $<.2$ & .31 & $<.04$ & $<.1$ & $<.4$ & $<.06$ & 3.6 & $<.02$ \\
\hline Q & $6 / 24 / 2008$ & $<.08$ & $<.2$ & $<.010$ & $<.2$ & $<.20$ & $<.04$ & .4 & $<.4$ & $<.06$ & $<1.8$ & $<.02$ \\
\hline $\mathrm{S}$ & $6 / 24 / 2008$ & $<.08$ & $<.2$ & $<.010$ & $<.2$ & $<.20$ & $<.04$ & $<.1$ & $<.4$ & $<.06$ & $<1.8$ & $<.02$ \\
\hline $\mathrm{F}$ & $6 / 24 / 2008$ & $<.08$ & $<.2$ & $<.010$ & $<.2$ & $<.20$ & $<.04$ & $<.1$ & $<.4$ & $<.06$ & $<1.8$ & $<.02$ \\
\hline $\mathrm{F}$ & 9/17/2008 & $<.08$ & $<.2$ & $<.010$ & $<.2$ & $<.20$ & $<.04$ & $<.1$ & $<.4$ & $<.06$ & $<1.8$ & $<.02$ \\
\hline $\mathrm{F}$ & 9/26/2008 & E,n.04 & 1.5 & $<.010$ & $<.2$ & .27 & $<.04$ & $<.1$ & 2.0 & $<.06$ & 3.0 & $<.02$ \\
\hline $\mathrm{F}$ & $11 / 18 / 2008$ & $<.06$ & $<.2$ & $<.010$ & $<.02$ & $<.12$ & $<.06$ & $<.008$ & $<.4$ & $<.02$ & $<2.0$ & $<.01$ \\
\hline
\end{tabular}

${ }^{1}$ Deionized water used to clean equipment 
[RPD, relative percent difference, which is defined as [(sample value - replicate value)/[(sample value + replicate value)/2]] x 100; $\mu \mathrm{S} / \mathrm{cm}$, microsiemens per centimeter; ${ }^{\circ} \mathrm{C}$, degrees Celsius; $\mathrm{mg} / \mathrm{L}$, milligrams per liter; E, value estimated by laboratory; $\mathrm{CaCO}_{3}$, calcium carbonate; $\mathrm{SiO}_{2}$, silicon dioxide; $\mathrm{N}$, nitrogen; $\mathrm{n}$, value less than the minimum reporting level; <, less than; $\mathrm{ND}$, not determined because data were less than the minimum reporting level: $\mu \mathrm{g} / \mathrm{L}$, micrograms per liter]

\begin{tabular}{|c|c|c|c|c|c|c|c|c|c|c|c|c|}
\hline \multirow[t]{2}{*}{$\begin{array}{r}\text { Well name } \\
\text { Sample date }\end{array}$} & \multicolumn{3}{|c|}{$\begin{array}{c}\mathrm{D} 6 \\
3 / 19 / 2007 \\
\end{array}$} & \multicolumn{3}{|c|}{$\begin{array}{c}D 6 \\
6 / 21 / 2007 \\
\end{array}$} & \multicolumn{3}{|c|}{$\begin{array}{c}\text { D6 } \\
9 / 5 / 2007 \\
\end{array}$} & \multicolumn{3}{|c|}{$\begin{array}{c}D 6 \\
11 / 19 / 2007\end{array}$} \\
\hline & Sample & Replicate & RPD & Sample & Replicate & RPD & Sample & Replicate & RPD & Sample & Replicate & $\mathrm{RPD}$ \\
\hline $\mathrm{pH}$, laboratory (standard units) & 7.2 & 7.2 & 0 & 7.2 & 7.2 & 0 & 7.2 & 7.2 & 0 & 7.3 & 7.3 & 0 \\
\hline Specific conductance, lab $\left(\mu \mathrm{S} / \mathrm{cm}\right.$ at $\left.25^{\circ} \mathrm{C}\right)$ & E 17,600 & E 17,500 & 1 & E 17,600 & E 17,700 & -1 & E 17,700 & E 17,600 & 1 & E 17,300 & E 17,300 & 0 \\
\hline Calcium, dissolved $(\mathrm{mg} / \mathrm{L})$ & 436 & 412 & 6 & 424 & 417 & 2 & 436 & 457 & -5 & 458 & 439 & 4 \\
\hline Magnesium, dissolved (mg/L) & 2,460 & 2,350 & 5 & 2,350 & 2,310 & 2 & 2,430 & 2,540 & -4 & 2,450 & 2,400 & 2 \\
\hline Potassium, dissolved (mg/L) & 14.7 & 14.1 & 4 & 14.6 & 13.7 & 6 & 13.5 & 14.6 & -8 & 14.5 & 14.2 & 2 \\
\hline Sodium, dissolved (mg/L) & 2,300 & 2,420 & -5 & 2,330 & 2,310 & 1 & 2,280 & 2,360 & -3 & 2,360 & 2,270 & 4 \\
\hline Acid neutralizing capacity, titration to $\mathrm{pH} 4.5, \mathrm{lab}\left(\mathrm{mg} / \mathrm{L}\right.$ as $\left.\mathrm{CaCO}_{3}\right)$ & 649 & 648 & $<1$ & 648 & 648 & 0 & 650 & 650 & 0 & 650 & 649 & $<1$ \\
\hline Bromide, dissolved (mg/L) & 4.60 & 4.53 & 2 & 4.49 & 4.35 & 3 & 4.42 & 4.21 & 5 & 4.45 & 4.46 & $<1$ \\
\hline Chloride, dissolved (mg/L) & 387 & 388 & $<1$ & 387 & 388 & $<1$ & 390 & 392 & -1 & 385 & 393 & -2 \\
\hline Fluoride, dissolved (mg/L) & 1.20 & 1.20 & 0 & 1.23 & 1.28 & -4 & 1.13 & 1.13 & 0 & 1.16 & 1.16 & 0 \\
\hline Silica, dissolved ( $\mathrm{mg} / \mathrm{L}$ as $\mathrm{SiO}_{2}$ ) & 21.6 & 19.8 & 9 & 20.8 & 20.7 & $<1$ & 20.9 & 20.9 & 0 & 21.8 & 21.7 & $<1$ \\
\hline Sulfate, dissolved (mg/L) & 13,500 & 13,600 & -1 & 13,400 & 13,600 & -1 & 13,700 & 13,700 & 0 & 14,000 & 14,100 & -1 \\
\hline Solids, residue on evaporation at $180^{\circ} \mathrm{C}$, dissolved $(\mathrm{mg} / \mathrm{L})$ & 22,800 & 22,900 & $<1$ & 21,400 & 21,300 & $<1$ & 21,400 & 22,500 & -5 & 22,500 & 22,900 & -2 \\
\hline Nitrogen ammonia plus organic, dissolved ( $\mathrm{mg} / \mathrm{L}$ as $\mathrm{N}$ ) & 1.5 & 1.6 & -6 & 1.6 & 1.5 & 6 & 1.6 & 1.5 & 6 & 1.6 & 1.6 & 0 \\
\hline Nitrogen ammonia plus organic, total $(\mathrm{mg} / \mathrm{L}$ as $\mathrm{N})$ & 1.7 & 1.7 & 0 & 1.6 & 1.6 & 0 & 1.7 & 1.6 & 6 & 1.6 & 1.6 & 0 \\
\hline Nitrogen ammonia, dissolved (mg/L as $\mathrm{N}$ ) & 0.123 & 0.132 & -7 & 0.076 & 0.081 & -6 & 0.079 & 0.079 & 0 & 0.068 & 0.065 & 5 \\
\hline Nitrite plus nitrate, dissolved ( $\mathrm{mg} / \mathrm{L}$ as $\mathrm{N}$ ) & 40.6 & 40.8 & $<1$ & 41.6 & 43.0 & -3 & 42.3 & 43.4 & -3 & 41.5 & 43.4 & -4 \\
\hline Phosphorus, dissolved (mg/L) & E,n 0.02 & $<.04$ & ND & 0.04 & E,n 0.04 & 0 & E,n 0.03 & E,n 0.03 & 0 & E.n 0.04 & E,n 0.03 & 29 \\
\hline Phosphorus, total (mg/L) & 0.04 & 0.04 & 0 & 0.04 & E,n 0.04 & 0 & 0.04 & E,n 0.03 & 29 & E,n 0.04 & E,n 0.04 & 0 \\
\hline Aluminum, dissolved $(\mu \mathrm{g} / \mathrm{L})$ & $<12.8$ & 12.4 & ND & $<16.0$ & $<16.0$ & $\mathrm{ND}$ & $<16.0$ & $<40.0$ & $\mathrm{ND}$ & $<12.8$ & $<12.8$ & ND \\
\hline Antimony, dissolved $(\mu \mathrm{g} / \mathrm{L})$ & E,n 0.40 & $<0.42$ & ND & $<0.60$ & E,n 0.40 & ND & $<1.50$ & $<1.50$ & $\mathrm{ND}$ & $<1.12$ & $<1.12$ & ND \\
\hline Arsenic, dissolved $(\mu \mathrm{g} / \mathrm{L})$ & 1.2 & 1.2 & 0 & 1.2 & E,n 1.1 & 9 & E,n 1.8 & $<3.0$ & ND & 1.2 & 1.2 & 0 \\
\hline Barium, dissolved $(\mu \mathrm{g} / \mathrm{L})$ & 5 & 5 & 0 & 6 & 7 & -15 & 6 & 6 & 0 & 6 & 6 & 0 \\
\hline Beryllium, dissolved $(\mu \mathrm{g} / \mathrm{L})$ & $<0.48$ & $<0.42$ & ND & $<0.60$ & $<0.60$ & $\mathrm{ND}$ & $<1.50$ & $<1.50$ & $\mathrm{ND}$ & $<0.06$ & $<0.06$ & ND \\
\hline Boron, dissolved $(\mu \mathrm{g} / \mathrm{L})$ & 792 & 774 & 2 & 809 & 802 & 1 & 848 & 854 & -1 & 855 & 853 & $<1$ \\
\hline Cadmium, dissolved $(\mu \mathrm{g} / \mathrm{L})$ & $<0.32$ & $<0.28$ & ND & $<0.40$ & $<0.40$ & ND & $<1.00$ & $<1.00$ & $\mathrm{ND}$ & $<0.32$ & $<0.32$ & $\mathrm{ND}$ \\
\hline Chromium, dissolved $(\mu \mathrm{g} / \mathrm{L})$ & $<0.96$ & $<0.84$ & ND & $<1.2$ & $<1.2$ & ND & $<3.0$ & $<3.0$ & ND & $<0.96$ & $<0.96$ & ND \\
\hline Cobalt, dissolved $(\mu \mathrm{g} / \mathrm{L})$ & 6.8 & 7.0 & -3 & 6.7 & 6.5 & 3 & 7.9 & 7.7 & 2 & 7.1 & 7.0 & 2 \\
\hline Copper, dissolved $(\mu \mathrm{g} / \mathrm{L})$ & E,n 2.4 & 2.3 & 3 & E,n 2.8 & E,n 3.1 & -9 & $<10.0$ & $<10.0$ & $\mathrm{ND}$ & $<8.0$ & $<8.0$ & $\mathrm{ND}$ \\
\hline Iron, dissolved $(\mu \mathrm{g} / \mathrm{L})$ & $<120$ & $<120$ & ND & $<90$ & $<90$ & ND & $<120$ & $<120$ & $\mathrm{ND}$ & $<120$ & $<120$ & ND \\
\hline Lead, dissolved $(\mu \mathrm{g} / \mathrm{L})$ & $<0.96$ & $<0.24$ & ND & $<1.20$ & $<1.20$ & ND & $<3.00$ & $<3.00$ & $\mathrm{ND}$ & $<0.64$ & $<0.64$ & ND \\
\hline Manganese, dissolved $(\mu \mathrm{g} / \mathrm{L})$ & 4,650 & 4,110 & 12 & 4,230 & 3,880 & 9 & 3,900 & 4,440 & -13 & 4,690 & 4,530 & 3 \\
\hline Mercury, dissolved $(\mu \mathrm{g} / \mathrm{L})$ & $<0.010$ & $<0.010$ & ND & $<0.010$ & $<0.010$ & ND & $<0.010$ & $<0.010$ & $\mathrm{ND}$ & $<0.010$ & $<0.010$ & ND \\
\hline Molybdenum, dissolved $(\mu \mathrm{g} / \mathrm{L})$ & 3.5 & 3.6 & -3 & 3.5 & 3.5 & 0 & 3.9 & 4.0 & -3 & 3.9 & 4.0 & -3 \\
\hline Nickel, dissolved $(\mu \mathrm{g} / \mathrm{L})$ & 8.1 & 8.2 & -1 & 9.1 & 8.5 & 7 & 10.6 & 11.8 & -11 & 10.2 & 12.8 & -23 \\
\hline Selenium, dissolved $(\mu \mathrm{g} / \mathrm{L})$ & 67.3 & 68.9 & -2 & 62.9 & 63.6 & -1 & 61.8 & 61.0 & 1 & 74.4 & 66.0 & 12 \\
\hline Silver, dissolved $(\mu \mathrm{g} / \mathrm{L})$ & $<0.8$ & $<0.7$ & ND & $<1.0$ & $<1.0$ & ND & $<2.5$ & $<2.5$ & $\mathrm{ND}$ & $<0.8$ & $<0.8$ & ND \\
\hline Strontium, dissolved $(\mu \mathrm{g} / \mathrm{L})$ & 16,800 & 16,500 & 2 & 16,700 & 16,600 & 1 & 17,300 & 17,800 & -3 & 18,100 & 17,400 & 4 \\
\hline Tungsten, dissolved $(\mu \mathrm{g} / \mathrm{L})$ & $<0.48$ & $<0.1$ & ND & $<0.60$ & $<0.60$ & ND & $<1.5$ & $<1.5$ & ND & $<0.48$ & $<0.48$ & ND \\
\hline Zinc, dissolved $(\mu \mathrm{g} / \mathrm{L})$ & E,n 2.9 & $<4.2$ & ND & E,n 3.5 & E,n 3.3 & 6 & $<15.0$ & $<15.0$ & $\mathrm{ND}$ & $<14.4$ & $<14.4$ & ND \\
\hline Uranium, natural, dissolved $(\mu \mathrm{g} / \mathrm{L})$ & 173 & 181 & -5 & 173 & 174 & -1 & 179 & 185 & -3 & 200 & 198 & 1 \\
\hline
\end{tabular}


Table 12. Comparison of water-quality data for groundwater and replicate samples collected near Deer Trail, Colorado, 2007 and 2008.—Continued

[RPD, relative percent difference, which is defined as [(sample value - replicate value)/[(sample value + replicate value)/2]] x $100 ; \mu \mathrm{S} / \mathrm{cm}$, microsiemens per centimeter; ${ }^{\circ} \mathrm{C}$, degrees Celsius; $\mu \mathrm{g} / \mathrm{L}$, milligrams per liter; $\mathrm{E}$, value estimated by laboratory; $\mathrm{CaCO}_{3}$, calcium carbonate; $\mathrm{SiO}_{2}$, silicon dioxide; $\mathrm{N}$, nitrogen; $\mathrm{n}$, value less than the minimum reporting level; <, less than; $\mathrm{ND}$, not determined because data were less than the minimum reporting level; $\mu \mathrm{g} / \mathrm{L}$, micrograms per liter]

\begin{tabular}{|c|c|c|c|c|c|c|c|c|c|c|c|c|}
\hline \multirow[t]{2}{*}{$\begin{array}{r}\text { Well name } \\
\text { Sample date }\end{array}$} & \multicolumn{3}{|c|}{$\begin{array}{c}\text { D6 } \\
3 / 26 / 2008\end{array}$} & \multicolumn{3}{|c|}{$\begin{array}{c}\text { D6 } \\
6 / 23 / 2008\end{array}$} & \multicolumn{3}{|c|}{$\begin{array}{c}D 6 \\
9 / 18 / 2008\end{array}$} & \multicolumn{3}{|c|}{$\begin{array}{c}\text { D6 } \\
11 / 19 / 2008\end{array}$} \\
\hline & Sample & Replicate & RPD & Sample & Replicate & RPD & Sample & Replicate & RPD & Sample & Replicate & RPD \\
\hline pH, laboratory (standard units) & 7.3 & 7.3 & 0 & 7.2 & 7.2 & 0 & 7.3 & 7.3 & 0 & 7.2 & 7.2 & 0 \\
\hline Specific conductance, lab $\left(\mu \mathrm{S} / \mathrm{cm}\right.$ at $\left.25^{\circ} \mathrm{C}\right)$ & E 17,500 & E 17,600 & -1 & E 17,400 & E 17,300 & 1 & E 17,600 & E 17,600 & 0 & E 17,500 & E 17,600 & -1 \\
\hline Calcium, dissolved (mg/L) & 453 & 453 & 0 & 438 & 433 & 1 & 437 & 428 & 2 & 443 & 443 & 0 \\
\hline Magnesium, dissolved (mg/L) & 2,450 & 2,520 & -3 & 2,270 & 2,340 & -3 & 2,160 & 2,130 & 1 & 2,490 & 2,490 & 0 \\
\hline Potassium, dissolved (mg/L) & 15.1 & 15.3 & -1 & 14.2 & 13.8 & 3 & 14.8 & 14.9 & -1 & 14.8 & 14.8 & 0 \\
\hline Sodium, dissolved (mg/L) & 2,300 & 2,320 & -1 & 2,160 & 2,160 & 0 & 2,410 & 2,340 & 3 & 2,350 & 2,350 & 0 \\
\hline Acid neutralizing capacity, titration to $\mathrm{pH} 4.5, \mathrm{lab}\left(\mathrm{mg} / \mathrm{L}\right.$ as $\mathrm{CaCO}_{3}$ ) & 650 & 650 & 0 & 654 & 654 & 0 & 648 & 648 & 0 & 650 & 650 & 0 \\
\hline Bromide, dissolved (mg/L) & 4.37 & 4.38 & $<1$ & 4.26 & 4.22 & 1 & 4.30 & 4.31 & $<1$ & 4.27 & 4.24 & 1 \\
\hline Chloride, dissolved (mg/L) & 382 & 383 & $<1$ & 381 & 381 & 0 & 372 & 371 & $<1$ & 368 & 371 & -1 \\
\hline Fluoride, dissolved (mg/L) & 1.28 & 1.30 & -2 & 1.18 & 1.18 & 0 & 1.24 & 1.23 & 1 & 1.22 & 1.21 & 1 \\
\hline Silica, dissolved ( $\mathrm{mg} / \mathrm{L}$ as $\mathrm{SiO}_{2}$ ) & 21.4 & 21.2 & 1 & 19.4 & 19.3 & 1 & 18.1 & 18.1 & 0 & 20.8 & 21.1 & -1 \\
\hline Sulfate, dissolved (mg/L) & 13,800 & 13,900 & -1 & 13,800 & 13,800 & 0 & 13,900 & 13,800 & 1 & 13,800 & 13,700 & 1 \\
\hline Solids, residue on evaporation at $180^{\circ} \mathrm{C}$, dissolved $(\mathrm{mg} / \mathrm{L})$ & 22,500 & 22,400 & $<1$ & 22,600 & 22,800 & -1 & 22,700 & 22,700 & 0 & 22,000 & 22,400 & -2 \\
\hline Nitrogen ammonia plus organic, dissolved (mg/L as N) & 1.5 & 1.5 & 0 & 1.7 & 1.6 & 6 & 1.5 & 1.5 & 0 & 1.6 & 1.5 & 6 \\
\hline Nitrogen ammonia plus organic, total (mg/L as $\mathrm{N}$ ) & 1.6 & 1.6 & 0 & 1.5 & 1.6 & -6 & 1.7 & 1.7 & 0 & 1.6 & 1.6 & 0 \\
\hline Nitrogen ammonia, dissolved (mg/L as N) & 0.086 & 0.086 & 0 & 0.080 & 0.080 & 0 & 0.072 & 0.074 & -3 & $<1.00$ & $<1.00$ & ND \\
\hline Nitrite plus nitrate, dissolved (mg/L as N) & 38.8 & 40.0 & -3 & 39.4 & 39.3 & $<1$ & 41.4 & 41.4 & 0 & 40.4 & 42.5 & -5 \\
\hline Phosphorus, dissolved (mg/L) & 0.04 & E,n 0.04 & 0 & 0.04 & E,n 0.04 & 0 & E,n 0.03 & E,n 0.03 & 0 & E,n 0.04 & 0.04 & 0 \\
\hline Phosphorus, total (mg/L) & E,n 0.03 & E,n 0.03 & 0 & E,n 0.04 & 0.04 & 0 & E,n 0.03 & E, n 0.04 & -29 & E,n 0.04 & E,n 0.03 & 29 \\
\hline Aluminum, dissolved $(\mu \mathrm{g} / \mathrm{L})$ & $<12.8$ & E,n 8.9 & ND & $<11.2$ & $<11.2$ & ND & $<16.0$ & $<16.0$ & ND & $<40.0$ & $<40.0$ & $\mathrm{ND}$ \\
\hline Antimony, dissolved $(\mu \mathrm{g} / \mathrm{L})$ & $<1.12$ & $<1.12$ & ND & $<0.98$ & $<0.98$ & ND & $<1.40$ & $<1.40$ & ND & E,n 0.40 & 0.50 & -22 \\
\hline Arsenic, dissolved $(\mu \mathrm{g} / \mathrm{L})$ & 1.5 & 1.5 & 0 & 1.6 & 1.5 & 6 & 1.2 & 1.3 & -8 & 1.3 & 1.4 & -7 \\
\hline Barium, dissolved $(\mu \mathrm{g} / \mathrm{L})$ & 6 & 6 & 0 & 6 & 6 & 0 & 5 & 5 & 0 & 5 & 6 & -18 \\
\hline Beryllium, dissolved $(\mu \mathrm{g} / \mathrm{L})$ & $<0.06$ & $<0.06$ & ND & $<0.06$ & $<0.06$ & ND & $<0.08$ & $<0.08$ & ND & $<0.20$ & $<0.20$ & ND \\
\hline Boron, dissolved $(\mu \mathrm{g} / \mathrm{L})$ & 871 & 876 & -1 & 760 & 767 & -1 & 708 & 714 & -1 & 707 & 715 & -1 \\
\hline Cadmium, dissolved $(\mu \mathrm{g} / \mathrm{L})$ & $<0.32$ & $<0.32$ & ND & E,n 0.14 & $<0.28$ & ND & $<0.40$ & $<0.40$ & ND & $<0.20$ & E,n 0.14 & ND \\
\hline Chromium, dissolved $(\mu \mathrm{g} / \mathrm{L})$ & $<0.96$ & $<0.96$ & ND & $<0.84$ & $<0.84$ & ND & $<1.2$ & $<1.2$ & ND & $<1.2$ & $<1.2$ & ND \\
\hline Cobalt, dissolved $(\mu \mathrm{g} / \mathrm{L})$ & 7.4 & 7.0 & 5 & 8.0 & 8.1 & -1 & 7.4 & 7.2 & 3 & 7.2 & 7.2 & 0 \\
\hline Copper, dissolved $(\mu \mathrm{g} / \mathrm{L})$ & $<8.0$ & $<8.0$ & $\mathrm{ND}$ & $<7.0$ & $<7.0$ & ND & $<10.0$ & $<10.0$ & ND & $<10.0$ & $<10.0$ & ND \\
\hline Iron, dissolved $(\mu \mathrm{g} / \mathrm{L})$ & $<120$ & $<120$ & ND & $<80$ & $<80$ & ND & $<80$ & $<80$ & ND & $<40$ & $<40$ & ND \\
\hline Lead, dissolved $(\mu \mathrm{g} / \mathrm{L})$ & $<0.64$ & E,n 0.48 & $\mathrm{ND}$ & $<0.56$ & $<0.56$ & ND & $<0.80$ & $<0.80$ & ND & $<0.60$ & E,n 0.30 & ND \\
\hline Manganese, dissolved $(\mu \mathrm{g} / \mathrm{L})$ & 4,460 & 4,320 & 3 & 4,590 & 4,570 & $<1$ & 4,190 & 4,200 & $<1$ & 3,940 & 4,000 & -2 \\
\hline Mercury, dissolved $(\mu \mathrm{g} / \mathrm{L})$ & $<0.010$ & $<0.010$ & $\mathrm{ND}$ & $<0.010$ & $<0.010$ & ND & $<0.010$ & $<0.010$ & ND & $<0.010$ & $<0.010$ & ND \\
\hline Molybdenum, dissolved $(\mu \mathrm{g} / \mathrm{L})$ & 3.6 & 3.4 & 5 & 4.1 & 4.1 & 0 & 3.2 & 3.4 & -6 & 3.4 & 3.5 & -3 \\
\hline Nickel, dissolved $(\mu \mathrm{g} / \mathrm{L})$ & 11 & 10.8 & 2 & 13.7 & 13.1 & 4 & 14.3 & 13.8 & 4 & 11.5 & 11.6 & -1 \\
\hline Selenium, dissolved $(\mu \mathrm{g} / \mathrm{L})$ & 57.1 & 55.0 & 4 & 61.8 & 64.6 & -4 & 60.6 & 61.0 & -1 & 65.1 & 65.6 & -1 \\
\hline Silver, dissolved $(\mu \mathrm{g} / \mathrm{L})$ & $<0.8$ & $<0.8$ & $\mathrm{ND}$ & $<0.7$ & $<0.7$ & ND & $<1.0$ & $<1.0$ & ND & Е 0.1 & E 0.1 & 0 \\
\hline Strontium, dissolved $(\mu \mathrm{g} / \mathrm{L})$ & 17,900 & 18,100 & -1 & 17,600 & 17,600 & 0 & 17,500 & 16,900 & 3 & 17,000 & 17,100 & -1 \\
\hline Tungsten, dissolved ( $\mu \mathrm{g} / \mathrm{L})$ & $<0.48$ & $<0.48$ & ND & $<0.42$ & $<0.42$ & $\mathrm{ND}$ & $<0.60$ & $<0.60$ & ND & $<0.20$ & $<0.20$ & ND \\
\hline Zinc, dissolved $(\mu \mathrm{g} / \mathrm{L})$ & $<14.4$ & $<14.4$ & ND & $<12.6$ & $<12.6$ & ND & $<18.0$ & $<18$ & ND & $<16.0$ & $<16$ & ND \\
\hline Uranium, natural, dissolved $(\mu \mathrm{g} / \mathrm{L})$ & 167 & 164 & 2 & 187 & 192 & -3 & 196 & 194 & 1 & 179 & 181 & -1 \\
\hline
\end{tabular}



